U.S. Geological Survey Groundwater Resources Program

\title{
Three-Dimensional Model of the Geologic Framework for the Columbia Plateau Regional Aquifer System, Idaho, Oregon, and Washington
}

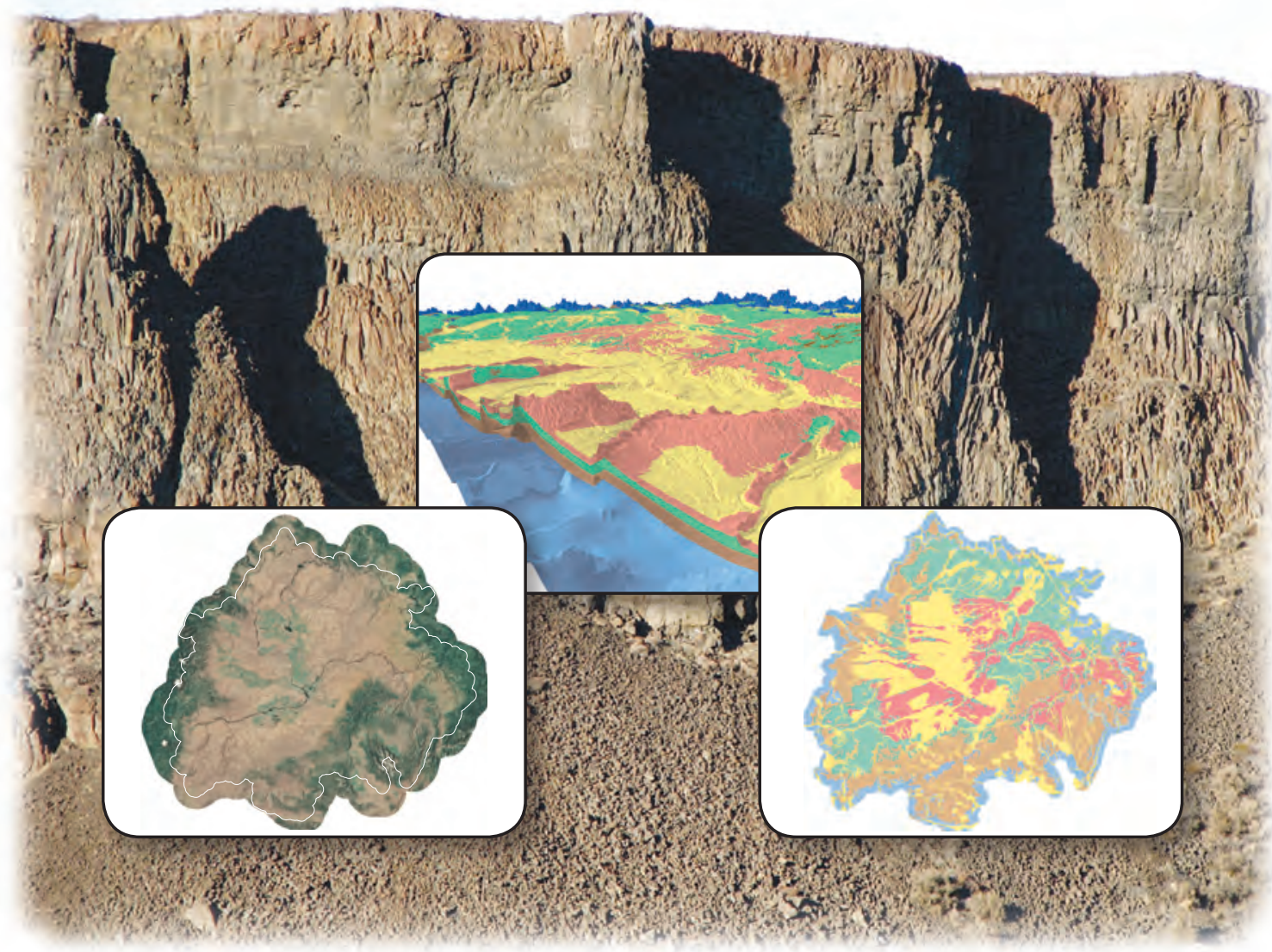

Scientific Investigations Report 2010-5246 
Cover: Lower left: Aerial photograph mosaic of Columbia Plateau, Idaho, Oregon, and Washington. (Photography compiled from various sources, available from Esri. For details see http://resources. arcgis.com/content/world-imagery-map.)

Center foreground: Oblique view (looking northeast) of a cross section through the geologic model surfaces in the vicinity of the Yakima Fold Belt, Washington.

Lower right: Model-generated surficial geology of the Columbia Plateau regional aquifer system, Idaho, Oregon, and Washington.

Background: Photograph of Frenchman's Coulee in the vicinity of Quincy, Washington. (Photograph taken by Peter Prehn, private citizen, 2008. Used with permission.) 


\section{Three-Dimensional Model of the Geologic Framework for the Columbia Plateau Regional Aquifer System, Idaho, Oregon, and Washington}

By Erick R. Burns, David S. Morgan, Rachael S. Peavler, and Sue C. Kahle

U.S. Geological Survey Groundwater Resources Program

Scientific Investigations Report 2010-5246 


\section{U.S. Department of the Interior \\ KEN SALAZAR, Secretary \\ U.S. Geological Survey \\ Marcia K. McNutt, Director}

\section{U.S. Geological Survey, Reston, Virginia: 2011}

For more information on the USGS - the Federal source for science about the Earth, its natural and living resources, natural hazards, and the environment, visit http://www.usgs.gov or call 1-888-ASK-USGS

For an overview of USGS information products, including maps, imagery, and publications, visit http://www.usgs.gov/pubprod

To order this and other USGS information products, visit http://store.usgs.gov

Any use of trade, product, or firm names is for descriptive purposes only and does not imply endorsement by the U.S. Government.

Although this report is in the public domain, permission must be secured from the individual copyright owners to reproduce any copyrighted materials contained within this report.

Suggested citation:

Burns, E.R., Morgan, D.S., Peavler, R.S., and Kahle, S.C., 2011, Three-dimensional model of the geologic framework for the Columbia Plateau Regional Aquifer System, Idaho, Oregon, and Washington: U.S. Geological Survey Scientific Investigations Report 2010-5246, 44 p. (Also available at http://pubs.usgs.gov/sir/2010/5246). 


\section{Contents}

Abstract
Introduction
Purpose and Scope
Previous Investigations.
Beogic Framework
Stratigraphy




\section{Figures}

Figure 1. Maps showing study area and data used for construction of the geologic model of the Columbia Plateau regional aquifer system, Idaho, Oregon, and Washington

Figure 2. Relation between mapped geologic units and geologic model units as defined for the Columbia Plateau regional aquifer system, Idaho, Oregon, and Washington 6

Figure 3. Diagrams showing general geologic modeling workflow $(A)$ and details of trend surface modeling $(B)$ used in the development of the geologic model for the Columbia Plateau regional aquifer system, Idaho, Oregon, and Washington ...

Figure 4. Diagram showing technique for removal of numerical artifacts associated with creating interpolation groups during development of the geologic model for the Columbia Plateau regional aquifer system, Idaho, Oregon, and Washington ... 13

Figure 5. Diagram showing example of physically unreasonable numerical artifacts resulting from the assumption that the distance between a bedrock trend surface and the land surface Digital Elevation Model are filled with sedimentary overburden

Figure 6. Diagrams showing model construction procedure for the sedimentary Overburden unit for the Columbia Plateau regional aquifer system, Idaho, Oregon, and Washington

Figure 7. Diagrams showing addition of trend-derived guide points to model the geometry of deeper geologic units

Figure 8. Map showing model-generated surficial geology and Columbia River Basalt extent of the Columbia Plateau regional aquifer system, Idaho, Oregon, and Washington

Figure 9. Map of model-generated tops for the $(A)$ Saddle Mountains Basalt unit, $(B)$ Wanapum Basalt unit, $(C)$ Grande Ronde Basalt unit, and $(D)$ Older Bedrock unit, Columbia Plateau regional aquifer system, Idaho, Oregon, and Washington

Figure 10. Maps showing model-generated thicknesses for the $(A)$ Overburden unit, $(B)$ combined Saddle Mountains Basalt and Mabton Interbed units, (C) combined Wanapum Basalt and Vantage Interbed units, and (D) Grande Ronde Basalt unit, Columbia Plateau regional aquifer system, Idaho, Oregon, and Washington

Figure 11. Histograms of residuals for the model-generated tops of geologic model units for the $(A)$ Saddle Mountains Basalt unit, $(B)$ Wanapum Basalt unit, $(C)$ Grande Ronde Basalt unit, and $(D)$ Older Bedrock unit, Columbia Plateau regional aquifer system, Idaho, Oregon, and Washington

Figure 12. Map showing spatial distribution of residuals for the model-generated top of the Grande Ronde Basalt unit, Columbia Plateau regional aquifer system, Idaho, Oregon, and Washington

Figure 13. Cross sections of the model-generated Columbia Plateau regional aquifer system, Idaho, Oregon, and Washington

Figure 14. Graph showing correlation between the model-generated thickness of the Saddle Mountains Basalt unit and thickness of the Mabton interbed, Columbia Plateau regional aquifer system, Idaho, Oregon, and Washington

Figure 15. Graph showing correlation between the model-generated thickness of the Wanapum Basalt unit and thickness of the Vantage interbed, Columbia Plateau regional aquifer system, Idaho, Oregon, and Washington 


\section{Conversion Factors, Datums, and Abbreviations and Acronyms}

Conversion Factors

\begin{tabular}{lll}
\hline \multicolumn{1}{c}{ Multiply } & \multicolumn{1}{c}{ By } & \multicolumn{1}{c}{ To obtain } \\
\hline foot $(\mathrm{ft})$ & 0.3048 & meter $(\mathrm{m})$ \\
mile $(\mathrm{mi})$ & 1.609 & kilometer $(\mathrm{km})$ \\
square mile $\left(\mathrm{mi}^{2}\right)$ & 2.590 & square kilometer $\left(\mathrm{km}^{2}\right)$ \\
cubic mile $\left(\mathrm{mi}^{3}\right)$ & 4.168 & cubic kilometer $\left(\mathrm{km}^{3}\right)$ \\
\hline
\end{tabular}

Temperature in degrees Celsius $\left({ }^{\circ} \mathrm{C}\right)$ may be converted to degrees Fahrenheit $\left({ }^{\circ} \mathrm{F}\right)$ as follows:

$$
{ }^{\circ} \mathrm{F}=\left(1.8 \times{ }^{\circ} \mathrm{C}\right)+32 .
$$

Datums

Vertical coordinate information is referenced to the North American Vertical Datum of 1988

(NAVD88).

Horizontal coordinate information is referenced to the North American Datum of 1983 (NAD83).

Elevation, as used in this report, refers to distance in feet above the vertical datum.

Abbreviations and Acronyms

CPRAS Columbia Plateau regional aquifer system

CRBG Columbia River Basalt Group

DEM digital elevation map

GIS geographical information system

GWMA Groundwater Management Area

NWIS National Water Information System

RASA Regional Aquifer-System Analysis program

USGS U.S. Geological Survey 
This page intentionally left blank. 


\title{
Three-Dimensional Model of the Geologic Framework for the Columbia Plateau Regional Aquifer System, Idaho, Oregon, and Washington
}

\author{
By Erick R. Burns, David S. Morgan, Rachael S. Peavler, and Sue C. Kahle
}

\section{Abstract}

As part of a U.S. Geological Survey Groundwater Resources Program study, a three-dimensional geologic model was constructed for approximately 53,000 square miles of the Columbia Plateau in Idaho, Oregon, and Washington. This model was constructed to define the general aquifer system geometry for use in a regional numerical groundwater flow model. Simplifications and assumptions consistent with this ultimate goal and with the uncertainty in the available data were made. The model units consist of Miocene-age Columbia River Basalt Group strata and younger sedimentary overburden covering approximately 44,000 square miles. Data were compiled from numerous databases and detailed studies that were completed during the past three decades. These data include stratigraphic interpretations of more than 13,000 wells and a contiguous compilation of surficial geology and structural features in the study area. These data were simplified and used to construct piecewise-smooth trend surfaces that represent upper and lower subsurface model unit boundaries in this complex folded and faulted terrain. The smoothness of the surfaces implicitly represents uncertainty in prediction of each surface resulting from data gaps, errors in borehole interpretations, errors in mapped contact locations, and uncertainty in the shape of the paleosurface upon which flood basalts were emplaced. Surfaces were recombined using a rule-based algorithm to construct a fully three-dimensional model with a 500 -foot grid resolution that is consistent with the data and for which error estimates may be made. The modeling process yielded improved estimates of unit volumes, refinement of location of large structural features, and identification of features that may be important for ongoing groundwater studies.

\section{Introduction}

The Columbia Plateau regional aquifer system (CPRAS) covers approximately $44,000 \mathrm{mi}^{2}$ of Idaho, Oregon, and Washington (fig. 1). The area supports a 6 billion dollar per year agricultural industry, leading the Nation in production of apples and nine other commodities (State of Washington, 2009; U.S. Department of Agriculture, 2009). Groundwater availability in the aquifers of the area is a critical waterresource management issue because the water demand for agriculture, economic development, and ecological needs is high.

The primary aquifers of the CPRAS are basaltic lava flows of the Columbia River Basalt Group (CRBG) and overlying basin-fill sediments. Water-resources issues that have implications for current and future groundwater availability in the region include (1) widespread waterlevel declines associated with development of groundwater resources for irrigation and other uses, (2) reduction in base flow to rivers and associated effects on temperature and water quality, and (3) current and anticipated effects of global climate change on recharge, base flow, and, ultimately, groundwater availability.

The U.S. Geological Survey (USGS) Groundwater Resources program began a study of the CPRAS in 2007 with the broad goals of (1) characterizing the hydrologic status of the system, (2) identifying trends in groundwater storage and use, and (3) quantifying groundwater availability. The study approach includes documenting changes in the hydrologic condition of the system, quantifying the hydrologic budget for the system, updating the regional geologic and hydrogeologic frameworks, and developing a groundwater-flow simulation model for the system. The groundwater flow model will be used to evaluate and test the conceptual model of the system and then will be used to evaluate groundwater availability under alternative development and climate scenarios. 


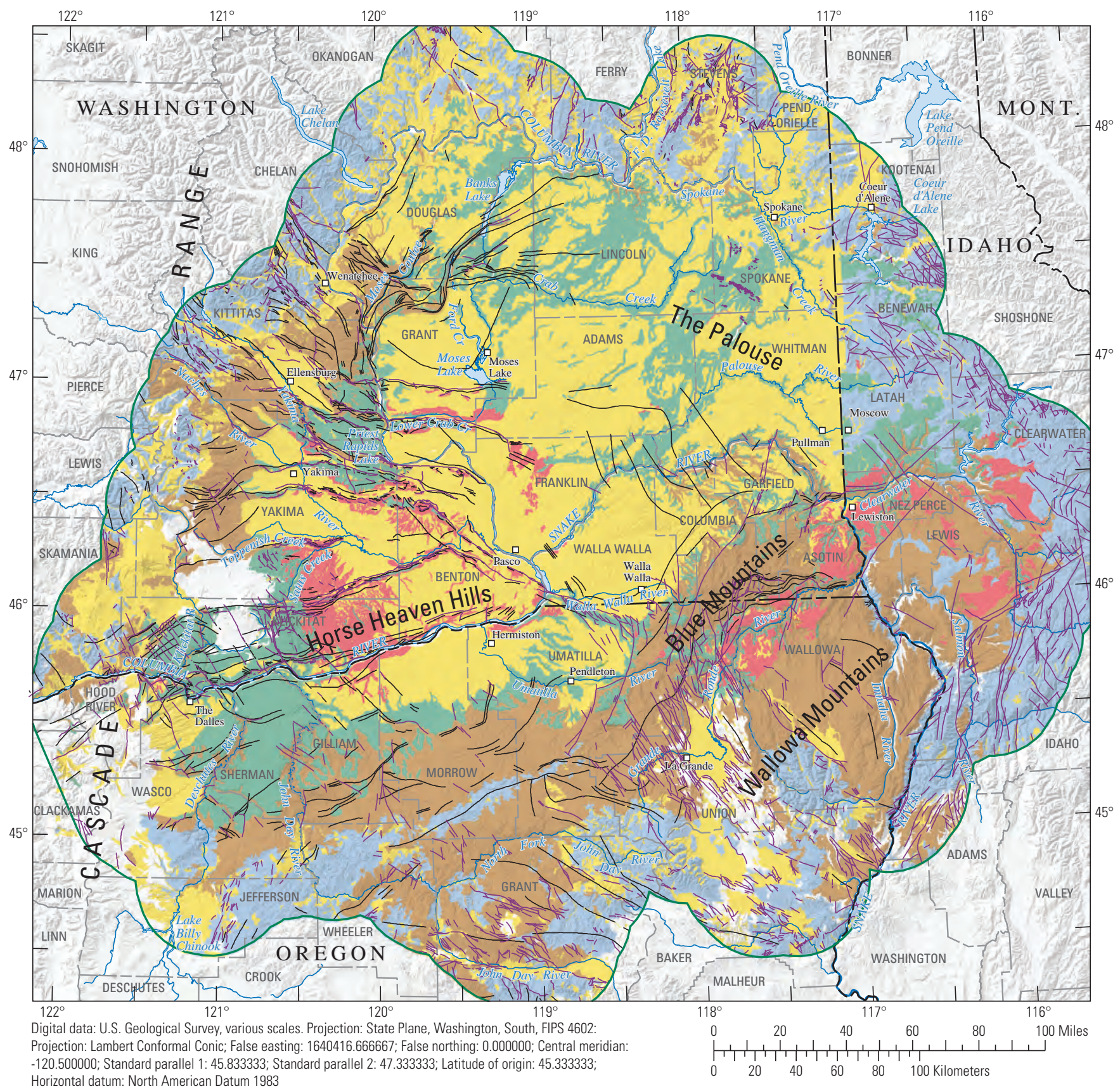
Horizontal datum: North American Datum 1983

\section{EXPLANATION}

\begin{tabular}{|ll}
\hline Geologic units & Data extent \\
Overburden (sedimentary) & Fault \\
Saddle Mountains Basalt & Fold \\
Wanapum Basalt & \\
Grande Ronde Basalt \\
Older Bedrock \\
$\begin{array}{l}\text { Geologic data not used for } \\
\text { modeling (post-CRBG } \\
\text { volcanics) }\end{array}$ \\
\hline
\end{tabular}

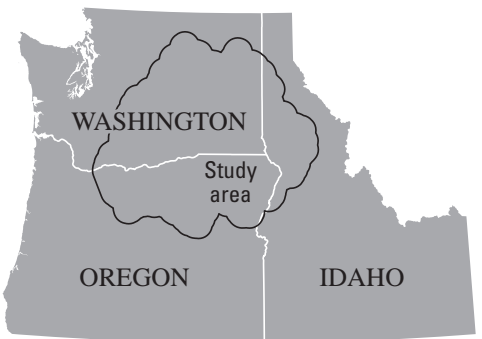

Figure 1. Study area and data used for construction of the geologic model of the Columbia Plateau regional aquifer system, Idaho, Oregon, and Washington. 


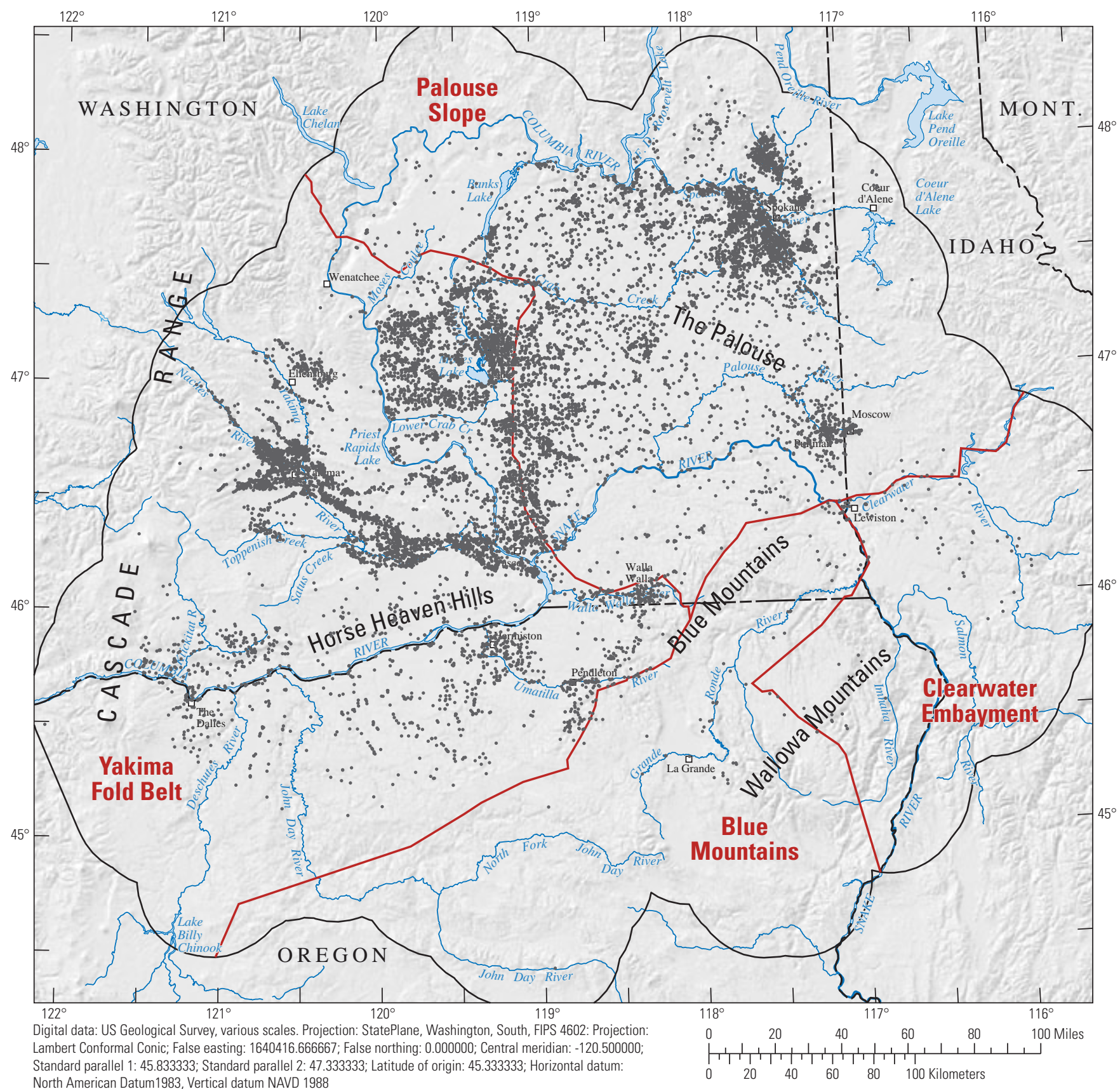

B. Location of wells with stratigraphic interpretations and generalized physiographic provinces (provinces modified from Snyder and Haynes, 2010).

\section{EXPLANATION}

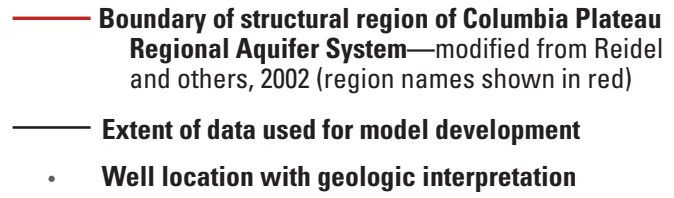

Figure 1.-Continued. 
The geologic model described in this report will be the foundation for the hydrogeologic framework of the groundwater flow model. The hydrogeologic framework will be constructed by identifying geologic features with similar or distinct hydraulic characteristics.

\section{Purpose and Scope}

The specific objective of this work was to update the geologic framework for the CPRAS by developing a digital, three-dimensional geologic model using available geologic mapping and well information. The model is intended to be used as the geologic foundation for a hydrogeologic model that will be used as input to a groundwater flow model for the CPRAS that will be developed as part of the groundwater availability assessment. This report describes the process used to generate the digital geologic model, as well as summarizes the resulting datasets.

\section{Previous Investigations}

Numerous reports, some regional and some sitespecific, document investigations regarding the geologic and hydrogeologic framework of the CPRAS. Each investigation has improved the understanding of the system within the limitations of the scope of the investigation or investigative techniques available at the time the study was conducted. The hydrogeologic units defined for most of these studies correspond to the geologic model units defined for this study.

In the early 1980s, the USGS began a study of the CPRAS as part of its Regional Aquifer-System Analysis (RASA) program. The geologic and hydrogeologic frameworks of the Columbia Plateau aquifer system were described in several reports including Drost and Whiteman (1986), Drost and others (1990), Gonthier (1990), and Whiteman and others (1994). The RASA study delineated seven hydrogeologic units - the overburden aquifer, the Saddle Mountains Basalt unit, the Wanapum Basalt unit, the Grande Ronde Basalt unit, two interbed units corresponding to the Mabton and Vantage interbeds, and a basement confining unit (Whiteman and others, 1994). The geologic and structure mapping of Swanson and others (1979a, 1979b, 1981) was the basis for the RASA framework in addition to analysis of geophysical logs, geologists logs, and chemical analysis of core or drill cuttings (Drost and others, 1990). Using data from the RASA study, two USGS studies covering subareas of the RASA study near the Horse Heaven Hills (fig. 1A) were completed in the 1980s (Davies-Smith and others, 1988; Packard and others, 1996). Both studies represented the CRBG as three basalt aquifers - the Saddle Mountains Basalt, Wanapum Basalt, and Grande Ronde Basalt units.

In 2000, the USGS began a hydrogeologic investigation of the Yakima River basin that resulted in two principal framework reports describing an area that covers about 6,900 $\mathrm{mi}^{2}$. This area generally covers the Yakima River and all of its tributary drainage basins within the footprint of the CRBG and upstream of the Columbia River (fig. 1A). The first report described the geologic and hydrogeologic framework of sedimentary deposits within the Yakima River basin (Jones and others, 2006); the second report described the extent and depth to top of basalt and interbed hydrogeologic units within the basin (Jones and Vaccaro, 2008). As in the earlier RASA and Horse Heaven Hills work, the major units recognized in the Yakima River basin study include, from youngest to oldest, the Saddle Mountains, Wanapum, and Grande Ronde Basalt units. In addition, the Mabton and Vantage interbed units that consist of sediments between individual basalt layers were included. Maps showing the extents and depth to top of these units were constructed on the basis of geologic mapping, previously constructed structure contour maps, and unit interpretations from about 3,000 well-log records. Welllog records included lithologic, geochemical, and geophysical descriptions.

In 2001, the Columbia Basin Groundwater Management Area (GWMA) Plan was adopted by the State of Washington to guide efforts to reduce nitrate concentrations in groundwater in Franklin, Grant, and Adams Counties. In 2005, Lincoln County was added to the GWMA resulting in a four-county area that covers about 8,300 $\mathrm{mi}^{2}$ in the central part of the study area. Detailed geologic and hydrogeologic framework investigations have been conducted for the GWMA and are summarized by Lindsey and others (2007) and Tolan and others (2007). A key component of the work was to refine the description of the geologic framework of the CRBG and overlying sediments within the GWMA. Information used to map the units included geologic maps, measured sections at outcrops, interpreted lithologic contacts from water well logs and specialty drill holes, petrographic and geochemical analyses of drill cuttings, and selected hydrogeologic reports.

Within the GWMA, the sediment overlying the CRBG was divided into five major units: (1) Quaternary sand dunes, (2) Quaternary alluvium, (3) Quaternary cataclysmic flood deposits, (4) Quaternary loess, and (5) Miocene-Pliocene Ringold Formation (Tolan and others, 2007). The upper two CRBG units (Saddle Mountains Basalt and Wanapum Basalt) were subdivided and the members were mapped by geochemistry, magnetic polarity, and relative position. The Saddle Mountains Basalt was subdivided into seven members and the Wanapum Basalt into three members (Tolan and others, 2007). Additionally, seven sediment interbeds that occur between basalt members were mapped. The lowest CRBG unit, the Grande Ronde Basalt, was not mapped at member level because of the great thickness of its uppermost member and relative lack of deep drilling information.

In 2005, the $700 \mathrm{mi}^{2}$ Palouse Basin basalt aquifer system was characterized on the basis of stratigraphic, lithologic, chemical, and magnetic data, and the information was used to develop a hydrogeologic geographic information system (GIS) database (Leek, 2006). The CRBG was divided into four units, Saddle Mountains, Wanapum, Grande Ronde, and Imnaha (Leek, 2006). Sedimentary interbeds were recognized as the 
Latah Formation, which is contemporaneous with the Vantage interbeds. Structure maps were constructed for the tops of the two dominant basalt aquifers, the Wanapum and Grande Ronde.

In 2006, the USGS created a website to present information about the Columbia River Basalt stratigraphy (U.S. Geological Survey, 2009a). In addition to background information about the CRBG and an extensive bibliography, the website contains detailed information for 151 wells in Oregon and 32 wells in Washington. Geologic information for water wells was on the basis of visual and geochemical analysis of carefully sampled borehole cuttings and interpretation of the driller's water well reports. Geochemical analysis of selected basalt cuttings provided oxide and trace element information to assist in classifying basalt into formation, members, and flow units.

\section{Geologic Framework}

The CPRAS covers approximately 44,000 mi2 of Idaho, Oregon, and Washington (fig. 1A). Kahle and others (2009) provided the context and interpreted geologic framework used in this report.

The Columbia Plateau is an intermontane basin between the Rocky Mountains and the Cascade Range that is filled with mostly Cenozoic basalt and sediment. The CRBG consists of a series of flows that erupted during various stages of the Miocene Age, 17 million to 6 million years ago. The basalt lava flowed from fissures and vents in Idaho, Oregon, and Washington. The number, extent, and thickness of flows vary depending on many factors, including proximity to vents, the volume of eruption, lava viscosity, cooling process, erosion, and topography over which the lava flowed (Swanson and others, 1979c; U.S. Geological Survey, 2009a). More than 300 flows have been identified, with individual flows ranging in thickness from 10 to more than $300 \mathrm{ft}$ (Tolan and others, 1989; Drost and others, 1990). Total thickness of the series of flows may be greater than $15,000 \mathrm{ft}$ in the central part of the study area near Pasco, Washington (Reidel and others, 2002) (fig.1A). Typically, lava erupted quickly and advanced away from the fissure or vent as a single, uniform sheet of lava; however, towards the margin of the CPRAS, depositional style commonly changed from sheet-flow to intra-canyon flows as the volume of lava decreased and the terrain became rugged enough to funnel flows into valleys and canyons. When the hiatus between flows was sufficiently long, soil developed or sediments were deposited on the surface of a flow. If these sediments were preserved, then a sedimentary interbed occurred between flows.

The CPRAS can be divided into four structural regions (Reidel and others, 2002), with two of these, the Yakima Fold Belt and the Palouse Slope, contained within the Columbia River basin proper (fig. 1B). The Yakima Fold Belt is included in the western and central parts of the Columbia Plateau and consists of a series of anticlinal ridges and synclinal valleys. The Palouse Slope in the northern and eastern parts of the plateau is much less deformed and dips gently westward. The Blue Mountains, a composite anticlinal structure, bounds the Yakima Fold Belt and Palouse Slope to the southeast. The Clearwater Embayment marks the eastward extent of the CPRAS along the foothills of the Rocky Mountains.

\section{Stratigraphy}

The majority of rocks exposed in the region are the CRBG, intercalated sedimentary rocks of the Ellensburg Formation, younger sedimentary rocks and deposits, Pleistocene cataclysmic flood deposits, eolian deposits, terrace gravels of modern rivers, and other localized deposits. The simplified stratigraphy used here was summarized by Kahle and others (2009).

\section{Sediment Stratigraphy}

Within the Yakima Fold Belt, Miocene sedimentary deposits of the Ellensburg Formation underlie, intercalate, and overlie the CRBG and compose most of the thickness of the unconsolidated deposits in the basinal areas (Jones and others, 2006). These continental sedimentary deposits include fluvial sands and gravels, overbank deposits, lacustrine deposits, alluvial-fan deposits, sandstone, conglomerate, and interbedded volcaniclastic sediments. The Mabton Interbed includes deposits of the Ellensburg Formation that overlie the Wanapum Basalt and underlie the Saddle Mountains Basalt. In eastern Washington and west-central Idaho, sediment of the Latah Formation underlies, intercalates, and overlies the CRBG (Leek, 2006). The Latah Formation consists mostly of clay, silt, and sand deposited in drainages blocked by encroaching basalt flows. Both the Latah Formation and the Vantage Member of the Ellensburg Formation form the major sedimentary interbeds occurring between the Grande Ronde and Wanapum Basalts. Pleistocene to Holocene sediments overlying the CRBG include flood gravels and slack water sediments, terrace gravels of modern rivers, and eolian deposits that include the Palouse Formation.

\section{Basalt Stratigraphy}

The thickest, most extensive, and hydrologically most important geologic unit in the CPRAS is the CRBG (Whiteman and others, 1994). The CRBG has been divided into six geologic formations by Swanson and others (1979c): Imnaha Basalt, Picture Gorge Basalt, Prineville Basalt, Grande Ronde Basalt, Wanapum Basalt, and Saddle Mountains Basalt. These formations are divided into members and further subdivided into flow units on the basis of field mapping, well logs, aeromagnetic surveys, geochemistry, and magnetic polarity (U.S. Geological Survey, 2009a). 
Flows belonging to the Imnaha Basalt, the oldest known in the CRBG, occur in western Idaho, eastern Washington, and Oregon (Kahle and others, 2009). The Picture Gorge and Prineville Basalt Formations are limited to areas in central Oregon defining the southern extent of the CRBG. The Imnaha Basalt and Grande Ronde Basalt (including Prineville and Picture Gorge) constitute 90 percent of the volume of the CRBG (Bjornstad and others, 2007). The remaining 10 percent includes the Wanapum and Saddle Mountains Basalts, which overlie the Grande Ronde Basalt. Flows of the Saddle Mountains Basalt are less widely distributed (fig. 1A). Folding and faulting of the basalts have occurred during the period of deposition and more recently. Distribution and thickness of younger basalt flows are controlled by structurally controlled valleys. During the Pleistocene, the surface of the basalt units was modified greatly during repeated catastrophic outburst flooding, which caused erosion of vast channels as well as removal and or deposition of overlying sediment.

\section{Geologic Model Units}

Generalized geologic model units recognized in this investigation include Overburden, Saddle Mountains Basalt, Mabton Interbed, Wanapum Basalt, Vantage Interbed, Grande Ronde Basalt, and Older Bedrock. These correspond directly to the hydrogeologic units defined by Kahle and others (2009), with minor exception (described in section, “Overburden Unit" ). The precise relation between geologic units and geologic model units are shown by a geologic column (fig. 2).

Basalt and interbed units are described in detail in Drost and others (1990), Whiteman and others (1994), and Jones and Vaccaro (2008). The surficial distribution of the sedimentary portion of the mapped Overburden unit, the three Columbia River Basalt units, and the Older Bedrock unit are shown in figure 1A. This map was developed by grouping surficial geologic units into selected model units on the basis of geologic age and stratigraphic position.

\begin{tabular}{|c|c|c|c|c|c|c|}
\hline Era & Period & Epoch & \multicolumn{3}{|c|}{ Geologic Units } & Geologic Model Units \\
\hline \multirow{11}{*}{ Cenozoic } & \multirow{2}{*}{ Quaternary } & Holocene & \multirow{2}{*}{\multicolumn{3}{|c|}{ All Quaternary Sedimentary Units }} & \multirow{3}{*}{ Overburden } \\
\hline & & Pleistocene & & & & \\
\hline & \multirow{9}{*}{ Tertiary } & Pliocene & \multicolumn{3}{|c|}{ All Pliocene Sedimentary Units } & \\
\hline & & \multirow{7}{*}{ Miocene } & \multirow{7}{*}{$\begin{array}{l}\text { Columbia } \\
\text { River } \\
\text { Basalt } \\
\text { Group }\end{array}$} & \multicolumn{2}{|c|}{$\begin{array}{l}\text { Saddle Mountains Basalt } \\
\text { flow members and interbeds }\end{array}$} & $\begin{array}{l}\text { Saddle Mountains } \\
\text { Basalt }\end{array}$ \\
\hline & & & & \multicolumn{2}{|c|}{ Mabton interbed } & Mabton Interbed \\
\hline & & & & \multicolumn{2}{|c|}{ Wanapum Basalt flow members } & Wanapum Basalt \\
\hline & & & & \multicolumn{2}{|c|}{ Vantage and Latah interbeds } & $\begin{array}{l}\text { Vantage } \\
\text { Interbed }\end{array}$ \\
\hline & & & & \multirow{2}{*}{$\begin{array}{l}\text { Grande Ronde } \\
\text { Basalt flow } \\
\text { members and } \\
\text { interbeds }\end{array}$} & $\begin{array}{l}\text { Prineville } \\
\text { Basalt }\end{array}$ & \multirow{3}{*}{$\begin{array}{c}\text { Grande Ronde } \\
\text { Basalt }\end{array}$} \\
\hline & & & & & $\begin{array}{c}\text { Picture } \\
\text { Gorge Basalt }\end{array}$ & \\
\hline & & & & \multicolumn{2}{|c|}{ Imnaha Basalt } & \\
\hline & & pre-Miocene & \multicolumn{3}{|c|}{ pre-Columbia River Basalt Group rocks } & Older Bedrock \\
\hline
\end{tabular}

Figure 2. Relation between mapped geologic units and geologic model units as defined for the Columbia Plateau regional aquifer system, Idaho, Oregon, and Washington. The dashed line between the interbeds and the overlying basalt unit indicates that the interbed thickness may be estimated as a fraction of the total distance between the top of the overlying and underlying basalt model units. 


\section{Overburden Unit}

Sedimentary deposits cover portions of the CRBG across the study area (fig. 1A). These deposits are of variable thickness, either filling topographic lows or forming a relatively thin mantle on bedrock highs. For this study, the focus is on identifying thick sedimentary deposits in valley bottoms that are regionally important for storing and transmitting groundwater. Thin, discontinuous deposits are ignored in the final model-generated Overburden unit.

As defined by Kahle and others (2009), the Overburden unit consists of undifferentiated unconsolidated to semiconsolidated sedimentary deposits and post-CRBG volcanic deposits of very limited extent ranging from Miocene to Holocene in age. In an effort to define hydraulically important units, Kahle and others (2009) delineate areas where the thickness of the Overburden unit likely exceeds $100 \mathrm{ft}$, with some wells penetrating thicknesses as much as $1,300 \mathrm{ft}$.

For the current study, the post-CRBG volcanic deposits were not explicitly grouped with the Overburden unit because post-CRBG lava flows are expected to have significantly different hydraulic properties from sedimentary overburden, and ultimately this model is to be used as the foundation for a groundwater flow model. The geologic modeling process allows for post-CRBG volcanic deposits to be grouped with Overburden if they exist in sediment-filled valleys and CRBG units when they are deposited in contact with CRBG units (see section, "Geologic Modeling Methodology"). This grouping preserves the important hydraulic character of the uppermost unit for use in the groundwater flow model. Because these post-CRBG volcanics were not used explicitly in the modeling process, the locations where post-CRBG volcanics are mapped as surficial geology are left blank in figure 1A.

\section{Saddle Mountains Basalt Unit}

The Saddle Mountains Basalt unit, the least extensive and youngest formation of the CRBG, consists of the Saddle Mountains Basalt and interbed members. Most of the unit is in the west-central part of the study area, with less continuous occurrences in the Blue Mountains and eastward into Idaho (fig. 1A). The Saddle Mountains Basalt unit has an estimated areal extent of about $8,000 \mathrm{mi}^{2}$, and the elevation of the top of the unit ranges from about 4,000 to $-280 \mathrm{ft}$. Thickness of the unit, based on well log data from 351 wells that fully penetrate this unit, ranged from about 0 to $990 \mathrm{ft}$ (Kahle and others, 2009).

\section{Mabton Interbed Unit}

The Mabton Interbed unit is the sedimentary interbed between the overlying Saddle Mountains Basalt unit and the underlying Wanapum Basalt unit. The Mabton Interbed unit consists of the Mabton Member of the Ellensburg Formation and is mostly in the west-central part of the study area. Limited surficial outcrops of the Mabton Interbed unit are present in the study area and the extent is assumed to be within the extent of the Saddle Mountains Basalt unit. The Mabton Interbed unit generally consists of clay, shale, claystone, clay with basalt, clay with sand, and sandstone. Thickness of the Mabton Interbed unit, based on well log data from 242 wells that fully penetrate this unit, ranges from about 0 to $520 \mathrm{ft}$ (Kahle and others, 2009).

\section{Wanapum Basalt Unit}

The Wanapum Basalt unit, composed of basalt and interbed members of the Wanapum Basalt, is in most of the north-central part of the study area (ig. $1 \mathrm{~A}$ ), and has an estimated areal extent of about 25,000 $\mathrm{mi}^{2}$. The elevation of the top of the Wanapum Basalt unit ranges from about 3,400 to $-1,000 \mathrm{ft}$ (Kahle and others, 2009). Much of the unit lies beneath the Overburden and Saddle Mountains Basalt units. Thickness of the Wanapum Basalt unit, based on well log data from 738 wells that fully penetrate this unit, ranges from about 0 to $1,200 \mathrm{ft}$ (Kahle and others, 2009).

\section{Vantage Interbed Unit}

The Vantage Interbed unit is the sedimentary interbed between the overlying Wanapum Basalt unit and the underlying Grande Ronde Basalt unit. Over most of the study area, this unit consists of the Vantage Member of the Ellensburg Formation; however, this unit includes sediment of the Latah Formation in the northeastern part of the study area. Limited surficial outcrops of this unit are present in the study area and the extent is assumed to be within the extent of the Wanapum Basalt unit. The Vantage Interbed unit consists of clay, shale, sandstone, tuff with claystone, and clay with basalt, but also may contain small amounts of sand and sandand-gravel. Interpretation of a limited number of well logs also indicates that the Vantage Interbed unit is not present in the southeastern part of the Yakima River basin and near the Cold Creek Syncline and Rattlesnake Hills Structure (Jones and Vaccaro, 2008). Thickness of the Vantage Interbed unit based on well log data from 444 wells that fully penetrate this unit ranges from about 0 to $320 \mathrm{ft}$ (Kahle and others, 2009). 


\section{Grande Ronde Basalt Unit}

The Grande Ronde Basalt unit is the oldest and most extensive of the basalt units. This unit underlies most of the study area (fig. 1A). The estimated areal extent of the Grande Ronde Basalt unit is about $42,000 \mathrm{mi}^{2}$ (Kahle and others, 2009).

The Grande Ronde Basalt unit contains the basalt and interbed members associated with the Grande Ronde Basalt as well as the less extensive Prineville, Picture Gorge, and Imnaha Basalts, and several stratigraphically consistent basalts mapped as undifferentiated in the compilation by Kahle and others (2009). Sedimentary interbeds in the Grand Ronde Basalt unit generally are rare and only a few feet thick, where present. The elevation of the top of the Grande Ronde Basalt unit ranges from 4,300 to $-2,100 \mathrm{ft}$ based on well log data used by Kahle and others (2009). Except near the periphery of the Columbia Plateau, where the unit thins and is fully penetrated by a number of water wells, thickness of the unit is largely unknown. Near the central part of the basin, the thickness of the unit is estimated to be greater than 15,000 ft.

\section{Older Bedrock Unit}

The Older Bedrock unit that borders and underlies the CPRAS is composed of various rock types older than the CRBG (Kahle and others, 2009). In Washington and Idaho, the rocks bordering the CPRAS consist mostly of sedimentary and granitic rocks. In Oregon, the CPRAS is bordered by sedimentary, volcaniclastic, volcanic, plutonic, and metamorphic rocks (Drost and others, 1990).

\section{Geologic Modeling Methodology}

The only previous attempt to build a cohesive and consistent three-dimensional representation of the major geologic units that covers the bulk of the CPRAS was accomplished as part of the Columbia Plateau Regional Aquifer-System Analysis (RASA) (Drost and others, 1990).

For this work, more than 2,000 wells in Washington and Oregon were used in conjunction with available geologic interpretations to construct maps of elevation of top and thickness of the Saddle Mountains, Wanapum, and Grande Ronde Basalt units, as well as thickness of the Overburden unit and the Mabton and Vantage interbeds (Drost and others, 1990). Since that work has been completed, several detailed studies of the geology and hydrology of parts of the CPRAS have been conducted (for example, Jones and others, 2006; Leek, 2006; Lindsey and others, 2007; Tolan and others, 2007; and Jones and Vaccaro, 2008) with considerable effort towards refinement of the geologic framework to better understand the hydrogeology. Additional well data from these published data sources plus the USGS National Water Information System (NWIS) results in a total of 13,226 wells with relevant information that may be used to refine the RASA work. The goal of the work described in this report was to rigorously incorporate all of this additional data into an improved threedimensional representation of the CPRAS.

For the RASA unit top elevation and thickness maps, a subset of the currently available well data was manually contoured to derive hydrologic unit elevations and thicknesses. Using few data has the advantage that contours may easily match data exactly. The following method is a numerical implementation of this process, except the resulting surfaces are trend surfaces that match all data on average. After construction of trend surfaces, geologic principles were used to define model surfaces and their extents. The trend modeling techniques were selected to aid in the evaluation of uncertainty of model-generated stratigraphic elevations, which is an important consideration when constructing a hydrogeologic framework for a groundwater flow model.

During development of the geologic model, data density was insufficient to resolve the interbed geometries explicitly. The interbed units are present over much of the study area, but are thin when compared with the thickness of the basalt units, and the interbed units are often discontinuous over a short distance. The interbed units constitute a portion of the thickness between two adjacent basalt unit tops, and the typical thickness of the interbed units may be described as a function of the total distance between these tops. This relation is described in section, "Modeling Major Sedimentary Interbeds," but these units are not explicitly shown on resulting maps or in cross-sections.

\section{General Geologic Modeling Workflow}

Geologic principles were used in the interpretation of the compiled data to generate all model unit geometries (fig. 3). The general process from compiling the data through creation of a three-dimensional solids model and assessing model fit is shown in figure $3 \mathrm{~A}$. It is called a solids model because each model-generated unit is completely defined at all points in space, filling a volume defined by the unit's extent, top, and bottom. In this way, the top, bottom, thickness, and volume are all fully consistent, meaning that the bottom of a unit is the top of the underlying unit, and the thickness at a given point is the distance between the two surfaces defining a unit's top and bottom. This was not true of the RASA interpreted surfaces (Drost and others, 1990) except in an approximate sense, because tops were created by contouring stratigraphic picks and thicknesses were created by contouring thickness points. The interpretation was independent for each top and each thickness, except where model-generated thickness was used to infer top elevation where no data were present. 
A.

\section{Geologic Modeling Workflow}

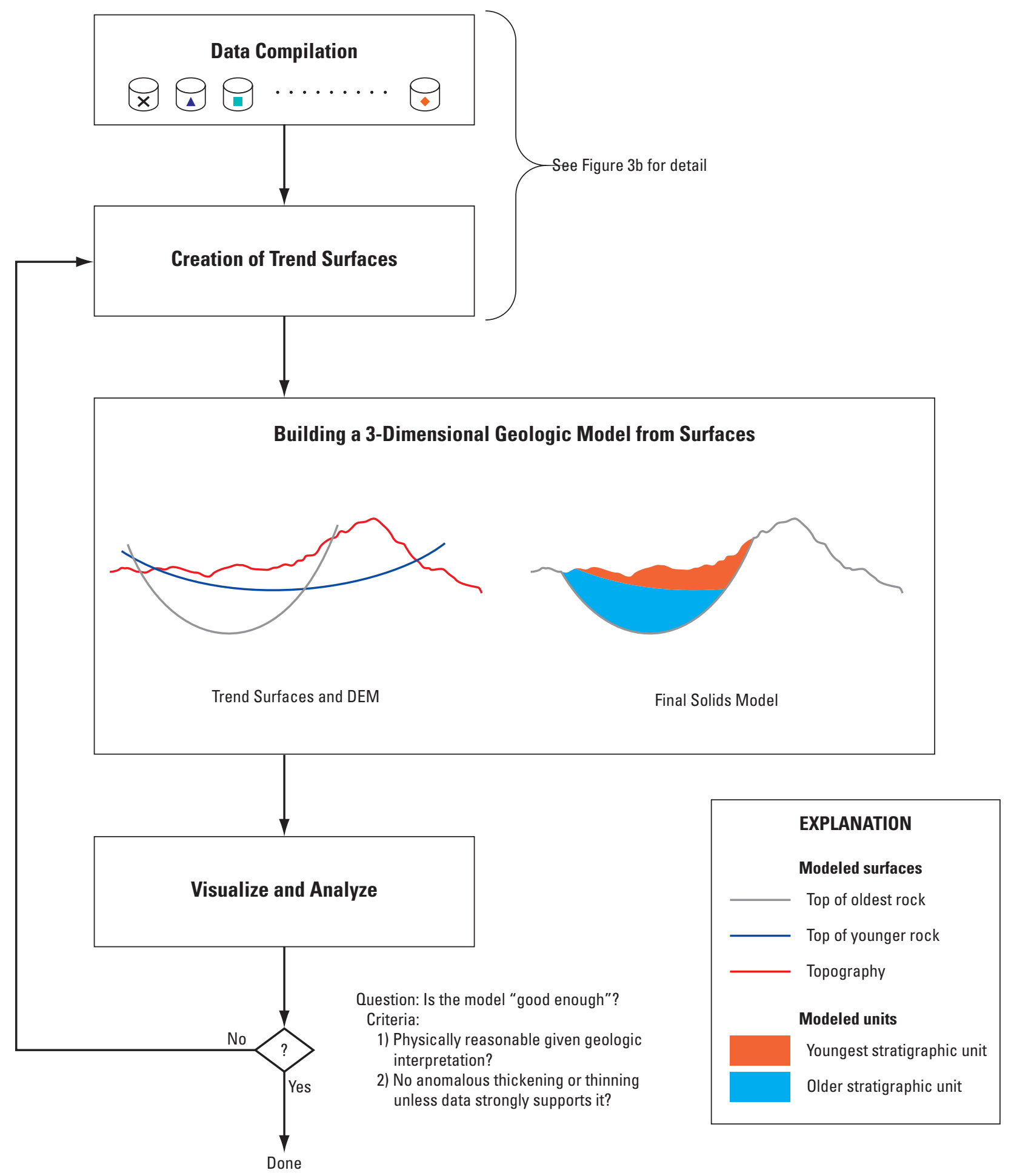

Figure 3. General geologic modeling workflow $(A)$ and details of trend surface modeling $(B)$ used in the development of the geologic model for the Columbia Plateau regional aquifer system, Idaho, Oregon, and Washington. 
B.

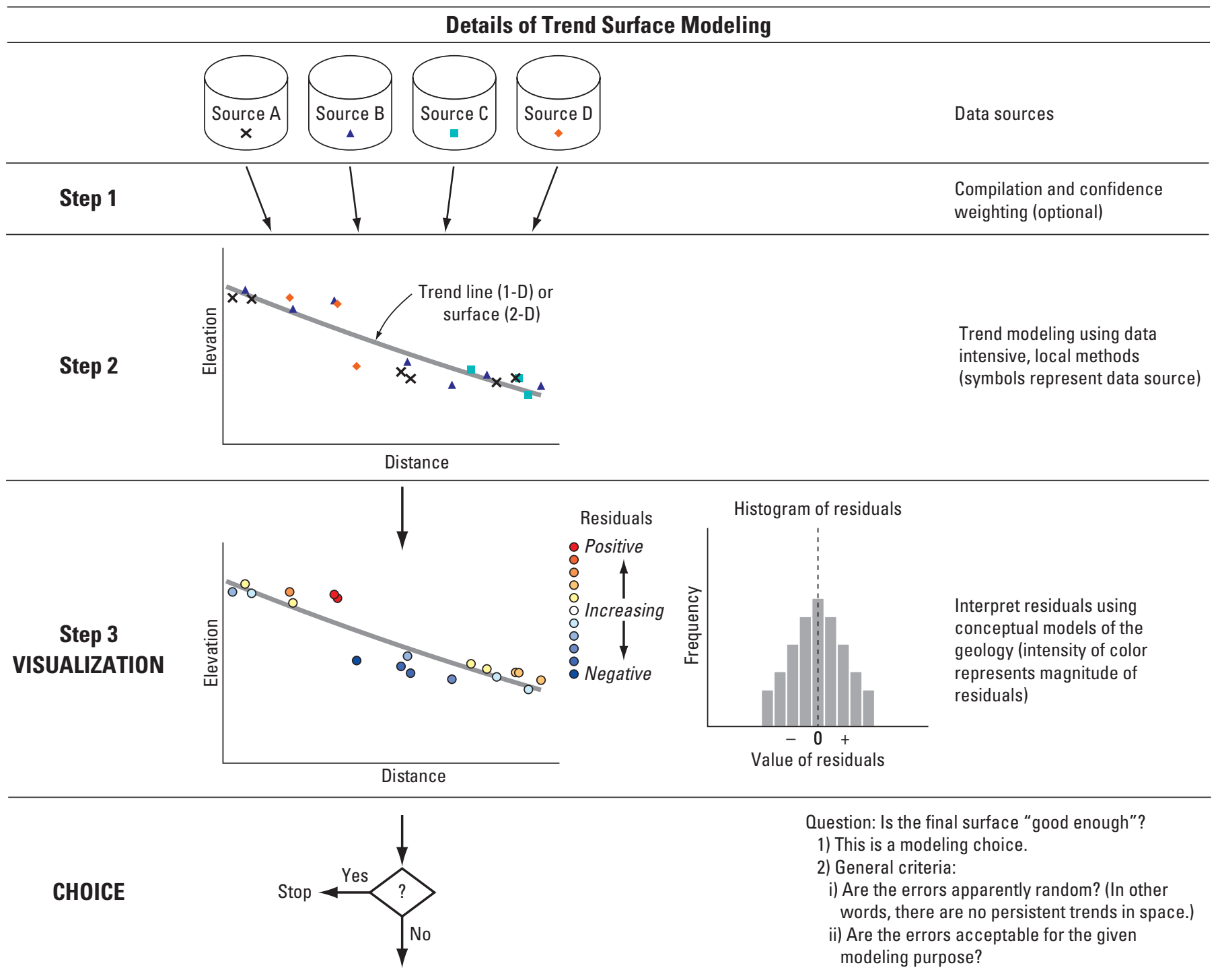

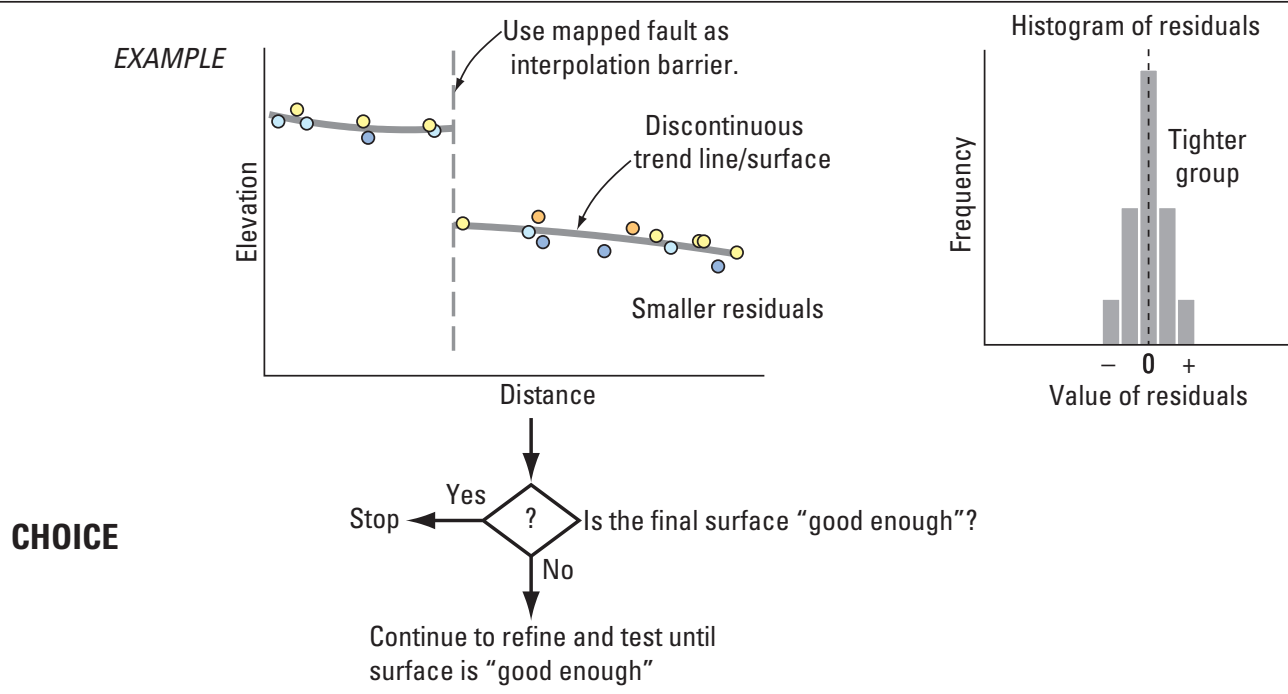

Add more information, repeat Steps 2 and 3, and recalculate. (intensity of color represents magnitude of residuals, same scale as step 3)

Figure 3.-Continued 
In contrast, the current method applies techniques to create model-generated surfaces on the basis of stratigraphic picks for the top of each of the major rock units. Then geologic principles are used, such as the laws of superposition, original horizontality, and lateral continuity, to create a solids model from which thicknesses are derived (fig. 3A). Because the major rock units to be represented are flood basalts, it is assumed that the flood basalts flowed out onto the paleotopography (the underlying geologic unit), filling depressions and flowing laterally away from the source. As a result, whenever model-generated surfaces cross each other, the overlying unit top is truncated where it meets the underlying unit top, and the void between the surfaces is filled with the overlying unit lithology. In the final step, the model is truncated with a surface representing the erosional top of rock across the study area. For much of the study area, CRBG or Pre-Miocene rock is at or very near land surface, so the solids model is truncated by the land-surface digital elevation map (DEM). For areas with thick sequences of sedimentary overburden, the erosional top of rock is corrected as described in section, "Modeling the Overburden Unit."

\section{Modeling Top Surfaces of the Major Units}

Various methods are available to create surfaces from data points for use in solids modeling. These methods may be divided into exact interpolators and trend models. Exact interpolation methods create surfaces that pass through each measured value and interpolate values between these known points. The rules of interpolation between known points are highly variable and prescribed by the method selected. In many cases, the surfaces generated by these interpolation methods may look physically unrealistic in a geologic sense, which is often an artifact of data clustering. In areas with a high density of data that have an appreciable amount of variability, the resulting surface is irregular (rugose), with a shape that is defined more by the data spacing and interpolation algorithm artifacts than the true underlying shape of the geologic deposit. Commonly, data are closely spaced in some areas and sparse in others. As a result, surfaces generated using exact interpolators are characterized by high rugosity in areas of high data density and a high degree of smoothness in areas with few data. The resulting surfaces commonly do not resemble the modeler's conceptualization of the shape of the geologic unit being simulated. However, even though the data may be "noisy," it may exhibit obvious trends for each of the units.

As an alternative, interpolation can be viewed as a statistical problem. Trend fitting algorithms tend to smooth the resulting interpolated surface in areas of high data density and provide a good fit to data in sparse data areas. The mismatch between the data and the trend surface (called residuals) is a measure of information that is not represented by the trend. The ideal trend surface is one for which the residuals are random or, more precisely, stationary. Stationary means that there are no trends in the randomness of the residuals across the region being simulated. This stationary trend surface is a best estimate (in a quantifiable sense) given that the data may not support resolution of fine-scale features into geologically relevant shapes. The residuals provide a method of estimating error associated with using the trend surface to estimate geologic surface elevation at an unknown location by using the kriging paradigm. Further, because stationarity of the data to be interpolated is an implicit assumption of most geostatistical algorithms (including kriging) (Deutsch, 2002, p. 180), decomposition of the data into a trend and stationary residual strengthens the assumptions used for error estimation of the resulting surfaces.

The process of creating smooth trend surfaces is shown for the two-dimensional case in figure 3B. First, data sources are compiled for use in the interpolation (step 1). Compilation may include an assessment of confidence in the data, resulting in a weighting scheme that reflects this confidence. Highdensity geologic data exhibit variability associated with measurement error, interpretive error, and natural variability of stratigraphic surfaces resulting from depositional and erosional processes. These data are then fit with a smooth curve (step 2). Misfit between data and the trend curve (residuals) are then assessed (step 3). Although the distribution of residuals may appear to be symmetrical in a histogram, implying the residuals are random, the spatial distribution of residuals also must be examined to detect persistent spatial trends. Spatial trends in residuals would indicate that the residuals are not stationary, as desired for the resulting model.

Following step 3, the fit is evaluated for adequacy. If the fit is determined to be inadequate, then additional information is added, and steps 2 and 3 are repeated. In the example (fig. 3B), a mapped fault is interpreted as the reason for the systematic trends in residuals. Addition of this fault as an interpolation barrier allows the data to be fit piecewise with smooth lines, thus greatly improving the fit as measured by both the histogram (or summary statistics) and the absence of persistent visual trends, indicating that the residuals are stationary. For this project, a piecewise implementation of the S-Plus local regression model called loess (Cleveland and others, 1992) was used. (To prevent confusion of the loess interpolation method with the wind-blown loess deposits within the CPRAS, the loess interpolation method is distinguished in this report by use of italics.)

The loess algorithm uses a local linear or quadratic function [specified by the degree variable $=1$ (first order polynomial) or 2 (second order polynomial), respectively] to make an estimate of elevation at any given location. During the interpolation, variable weights are assigned to data points on the basis of distance from the point being estimated using a tri-cube weight function. The amount of smoothing is prescribed by the span variable, with smoothness increasing as a function of span. A larger span means that more data are used to make the estimate at each location. The loess algorithm has many optional parameters, but the final parameter of note here is family. This parameter may have values of "Gaussian" or "Symmetric," which helps control the 
fit objective for the algorithm. The default value of "Gaussian" was used here, which results in a best local linear or quadratic fit (specified by the degree) that attempts to attain normally distributed residuals with a zero mean, resulting in a trend surface with the desired random residuals.

Loess is considered a data-intensive method because it requires densely sampled datasets for best results, and numerical artifacts may occur in low data density situations.

In practice, steps 2 and 3 (fig. $3 \mathrm{~B}$ ) proceed iteratively. After the first iteration, a visual analysis of residuals allows rapid assessment of locations where the loess trend surface does a poor job of fitting the data. For example, in heavily faulted areas, such as the Yakima area, elongate groups of adjacent dark red and dark blue colored residuals are indicative of significant offset on faults. These bands are the two-dimensional equivalent of the residuals shown in step 3, with all residuals on one side of a fault trace being persistently positive and the other side being persistently negative. Analysis of all such areas allows compilation of a simplified fault map for the Columbia Plateau that shows the areas of large amounts of offset by major faults or fault zones. As a simplification, all faults are assumed to be vertical, and whenever a unit is assumed to be faulted, all older underlying geologic units also are assumed to be faulted.

Incorporation of the faults as interpolation barriers (example in fig. 3B) during subsequent interpolations yields a much better fit, but the current version of loess in S-Plus does not support interpolation with barriers. To overcome this restriction, a script was written in the $\mathrm{S}$ programming language that allowed loess interpolation groupwise. Group numbers were defined in a geographic information system database by defining polygons that create natural groups that are bounded by geologic structural features. Group numbers were assigned to data residing in each group, and each group was interpolated separately. Although faults commonly provide clear boundaries for groups, faults in the study area are frequently discontinuous, requiring the modeler to select where to separate groups for the groupwise interpolation. This artificial separation of groups in the absence of a fault, however, may result in interpreted surfaces not joining smoothly (fig. 4). To rectify this potential problem, group boundaries were defined as necessary to facilitate loess trend removal, but after this step, loess estimates were retained only at known data points and for selected support points that ensure loess trends are preserved. These loess trend points are then reinterpolated using the default ArcGIS spline with barriers routine (exact interpolator) where the only barriers used are mapped faults that have sufficient offset to be visible in the residuals distribution. This technique results in a final surface that is smoothly connected between interpolation groups except where high-offset mapped faults allow disconnection (compare figs. 3B and 4 ).
Because the spline is exact and smooth and the loess points vary smoothly, all properties of the residual are retained and the resulting trend surface is virtually indistinguishable from the loess trend surface in most areas. The areas where the spline surface differs from the loess trend are in the space between interpolation groups where no trend support points are retained. In the absence of loess trend points, the spline will smoothly connect the closest points, which may not be the same as the trend model prediction (fig. 4). This method works well where the offset is small, but if the apparent offset is the result of a large structural fold rather than a fault, then the tightness of the model-generated fold will be a function of the data and loess support points retained for the spline model.

Many folds within the CPRAS tend to be relatively tight and over a short distance with faults commonly transitioning into folds along the fault trace. This feature of the geology implies that loess trend support points are good estimators of geologic contact elevation until the trend points are close to tight folds or faults. As a modeling assumption, prior to interpolation using spline with barriers, all loess trend support points are removed from the interpolation datasets if the points are within $2 \mathrm{mi}$ of a group barrier that is not mapped as a fault. This assumption means that unless there are data points within the 2-mi buffer to support a tighter fold, the spline surface will smoothly connect the trend points from adjacent groups over a 4-mi distance. If the fold is gentle (such as in fig. 4), then the effect is minimal; but if the fold is tighter than $4 \mathrm{mi}$ across ( $2 \mathrm{mi}$ on each side of the group line), then the model-generated fold radius may be different from reality unless data are available that define the fold more accurately (recall that only trend support points were removed, but that data were retained if present within the 2-mi buffer). An additional benefit of this modeling strategy is that faults may grade from high offset to zero offset along their trace as faults transition into a fold as is observed in many areas of the CPRAS.

Another benefit of using groups in the loess script is that it allows the modeler to vary the loess parameters degree and span on a groupwise basis. This ability was used sparingly and only when data density supported this action and reflected the need to capture some feature of the system, such as a tight fold exposed in the surficial geology and supported by well data. For all trend surfaces created, degree was set to one (local linear), and span was varied to create the smoothest fit to the data that removed persistent spatial trends in the residuals. In areas of high data density, it is possible to continue to dissect the data and remove additional small-scale trends, but given the regional modeling objectives, small-scale features were not resolved in all cases. The point at which small-scale trends or data anomalies are considered negligible relative to the modeling objectives is a modeling choice. 


\section{Use of Groups in the Absence of a Barrier}

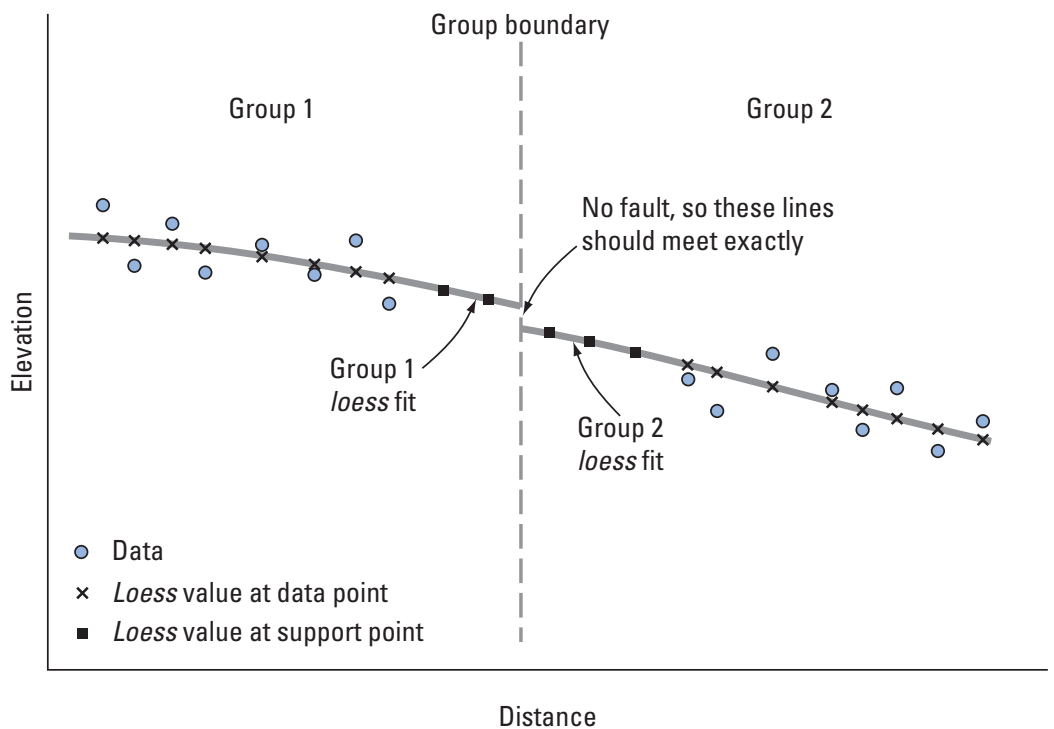

\section{Spline Interpolation for the Case that the Group Boundary is not an Interpolation Barrier (for example, it is not a fault)}

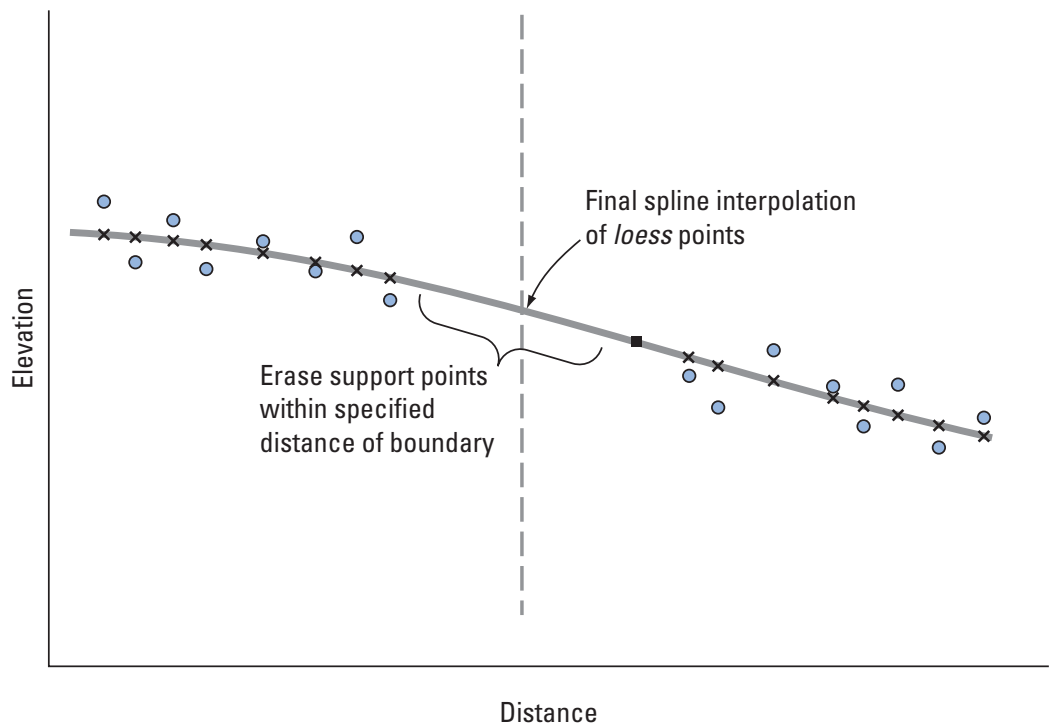

Figure 4. Technique for removal of numerical artifacts associated with creating interpolation groups during development of the geologic model for the Columbia Plateau regional aquifer system, Idaho, Oregon, and Washington. 
In summary, piecewise loess trend surfaces were created for the bounding surfaces of each of the rock units to be used in the modeling process (ig. 3B). These surfaces are smooth, and this smoothness represents the uncertainty in the predicted surface, which may be quantified using the data residuals. This smoothness will be retained in the final model except where the land surface DEM intersects the unit (fig. 3A). Because the Mabton and Vantage interbeds will be assumed to be present only where overlying CRBG units are present, the trend surfaces created for the CRBG and Older Bedrock units completely define the extent of the solids model except where erosion has created and filled space now occupied by the Overburden unit.

\section{Modeling the Overburden Unit}

Only sequences of overburden that potentially serve as aquifers connected with the regional flow system were modeled. The thickness of the Overburden unit is modeled as filling the space between the land surface and the top of the uppermost bedrock unit; however, it is a poor modeling assumption that sediment fills the distance between the underlying model trend surface and the land-surface DEM. This assumption works well for thick sedimentary deposits, but performs poorly in areas dominated by bedrock outcrops at land surface. Poor performance in areas with thin deposits occurs because the bedrock has an irregular surface, so using the trend of this surface will result in all bedrock highs being simulated as sedimentary deposits instead of erosion-resistant bedrock (fig. 5).

Another option that provides some benefits but introduces other problems is to model the overburden as a thickness that will be subtracted from the land-surface elevation. This method improves the representation of sedimentary overburden in areas dominated by bedrock outcrops, but subtracting thickness from a land-surface DEM using sparse data or a model-generated thickness trend map results in translating surface rugosity inherited from the DEM to the model-generated top of bedrock. Modeling the surface in this manner is inconsistent with the previous modeling assumption that buried surfaces should be simulated as smooth to reflect the uncertainty in the model-generated surface. Because the two approaches described above perform well in different situations, a hybrid of these approaches was used to create a top of bedrock surface (ig. 6), thereby defining the geometry of the Overburden unit.
Sufficient coverage of overburden thickness data (from wells and mapped surficial geology) is available to create a sedimentary overburden thickness map for areas within the CPRAS that form extensive sedimentary aquifers (fig. 6, step 1). To ensure that all streams are underlain by sediments, the model assumes that $25 \mathrm{ft}$ of overburden underlies streams for which no proximal data are available. Subtracting the smooth sedimentary thickness surface from the land-surface DEM gives a top of bedrock map (fig. 6. step 2); however, the resulting map inherits the rugosity of the topography even though the data do not support this resolution. This high rugosity top of bedrock is an estimate of the true top of bedrock.

The elevation of the top of thick hydraulically important deposits is controlled by depositional processes and is defined by the land-surface elevation of thick sequences of sedimentary overburden and stream elevations (fig. 6, step 3). Intersecting the high-rugosity top of bedrock estimate (step 2) with the depositional level surface (step 3) delineates areas where each surface is higher than the other (step 4). If the top of bedrock surface is higher than the depositional level surface, then erosionally resistant highs are assumed to occur (step 5). If the depositional level surface is higher than the top of rock surface, then sediment is assumed to overlie the rock. These assumptions work well in areas where bedrock is exposed in valley sides, providing a zero thickness of sedimentary overburden, or in steep-sided valleys.

The resulting map is used to define areas where sufficient sedimentary overburden is present to be included in the model. In areas where sedimentary overburden is assumed to be negligible, the top of bedrock is land surface (step 6). In areas where sedimentary overburden is to be simulated, the two-dimensional loess algorithm was utilized to construct a trend surface of the elevation of the top of rock using data from wells. The final top of bedrock model is constructed by stitching this trend surface to the areas where the bedrock is simulated as exposed.

The result is a bedrock surface that reflects the undulating land surface where bedrock is exposed, but is smooth where bedrock is overlain by sedimentary overburden (fig. 6 , Result). Thick sequences of overburden that are known to contain and transmit groundwater will be represented. This model-generated top of bedrock is now used in place of the land-surface topography DEM for the process illustrated in figure $3 \mathrm{~A}$, and overburden is simulated as filling the distance between the model-generated top of bedrock and the landsurface topography. 


\section{A - Reality}

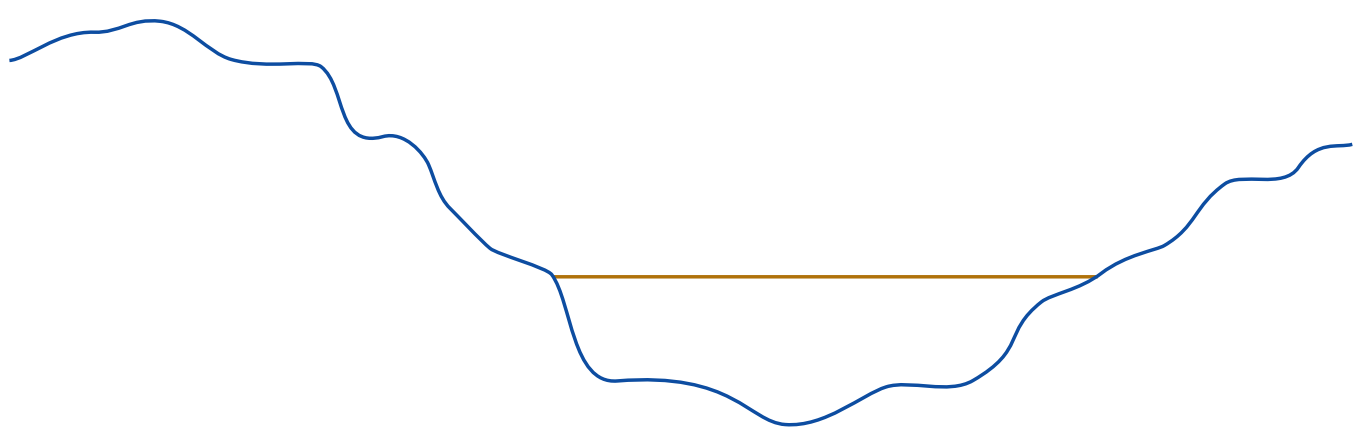

\section{B - Construct trend surface of rock}

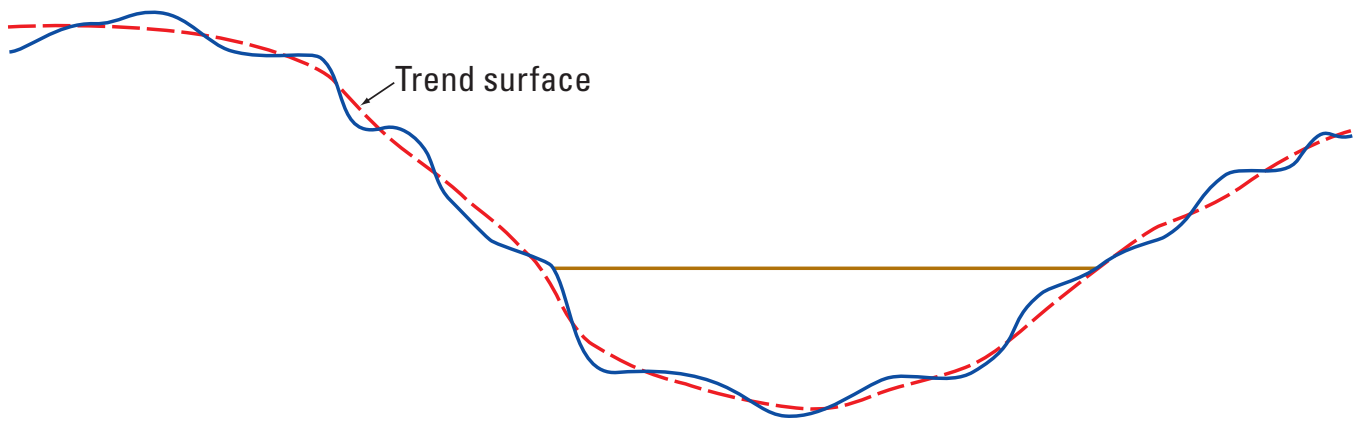

\section{C - Model assuming distance between trend and DEM is sediment}

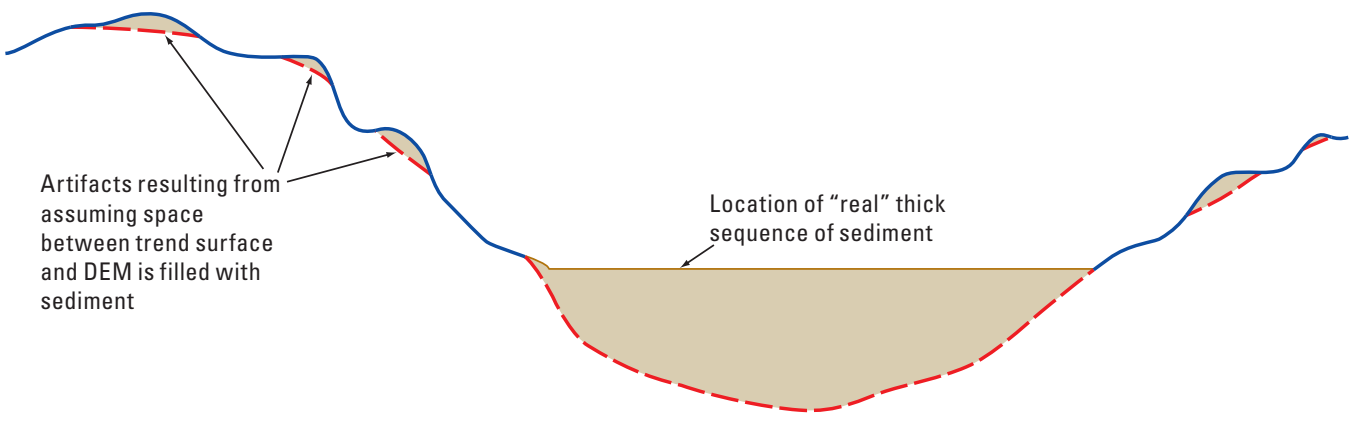

\section{D - Preferred model}

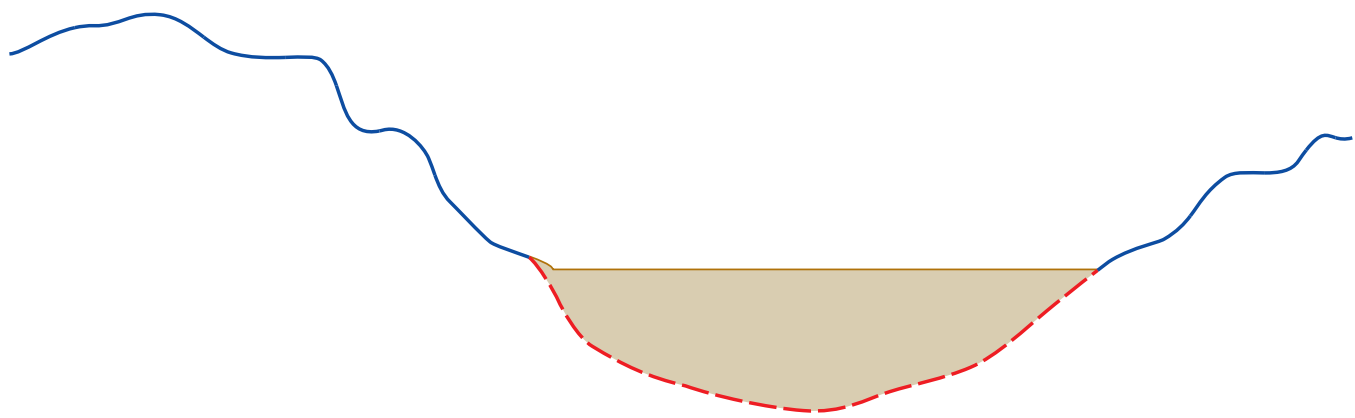

Figure 5. Example of physically unreasonable numerical artifacts resulting from the assumption that the distance between a bedrock trend surface and the land surface Digital Elevation Model are filled with sedimentary overburden: $(A)$ Actual bedrock surface, $(B)$ simulated trend bedrock surface, $(C)$ resulting numerical artifacts (small pockets of sediment on bedrock highs), and $(D)$ preferred simulation. 


\section{Step 1 - Single valley}

Estimate thickness of overburden filling low areas

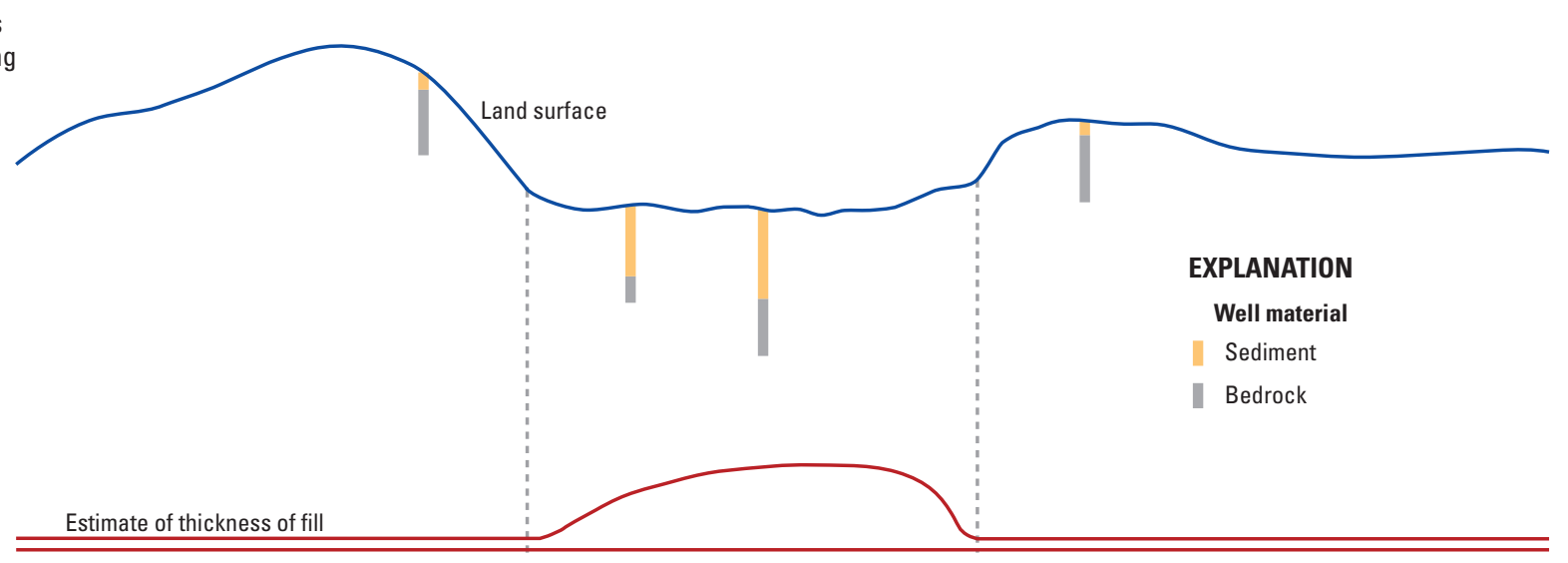

Step 2 - Single valley

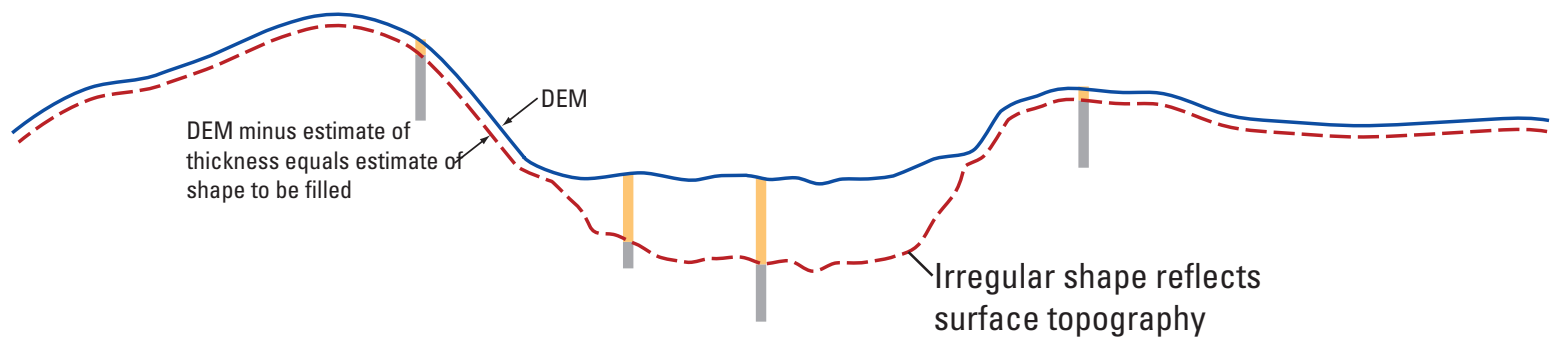

Step 3 - Single valley

Use wells with thick sequences of "sediment" to estimate surface representing top of thick basin fill sequences.
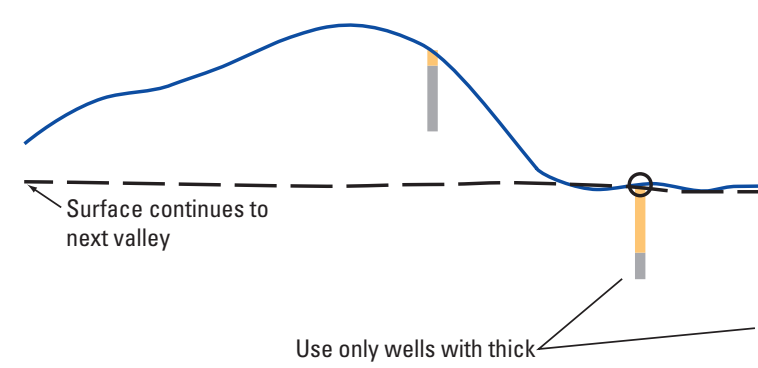
sequences of sediment

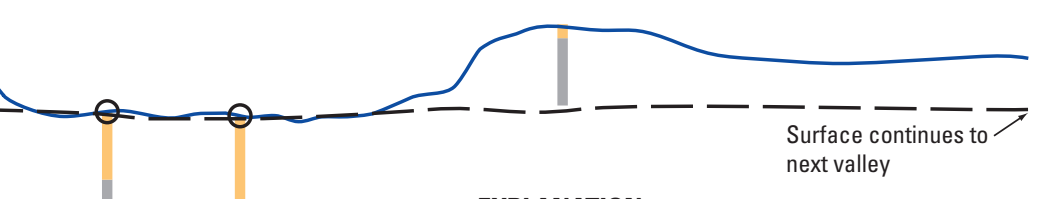

EXPLANATION

Land surface elevation of well with thick sediment

\section{Step 4 - Regional}

Intersect

estimate of top of bedrock with the above surface to get approximate extent of thick sequences of basin fill

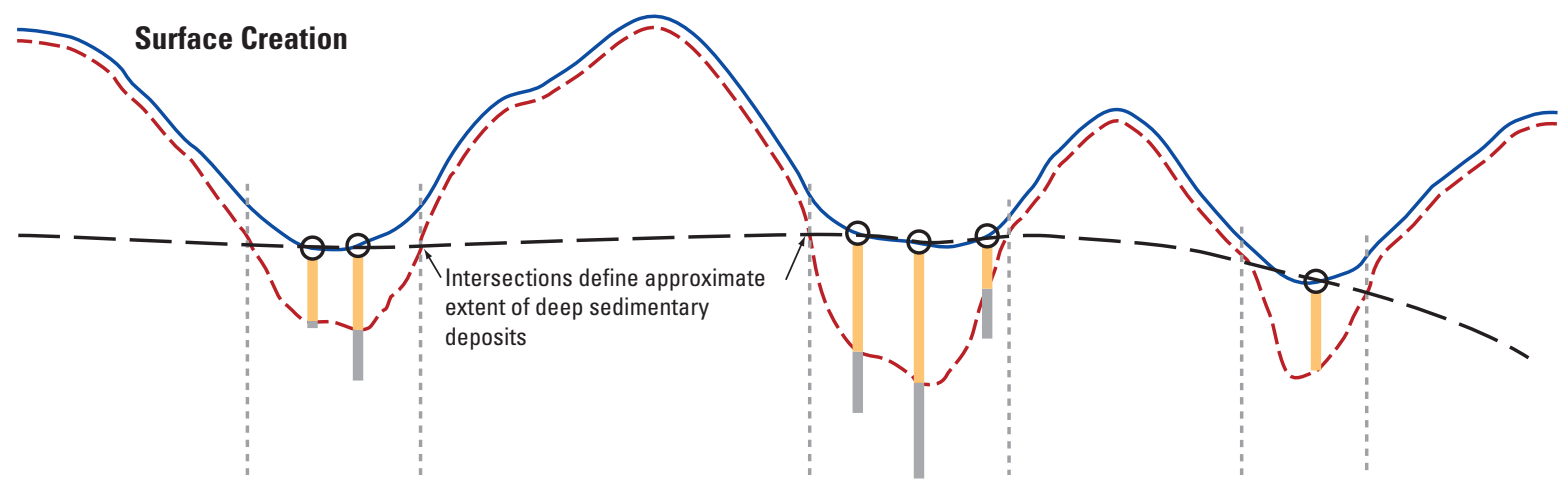

Figure 6. Model construction procedure for the sedimentary Overburden unit for the Columbia Plateau regional aquifer system, Idaho, Oregon, and Washington. 


\section{Step 5- Regional}

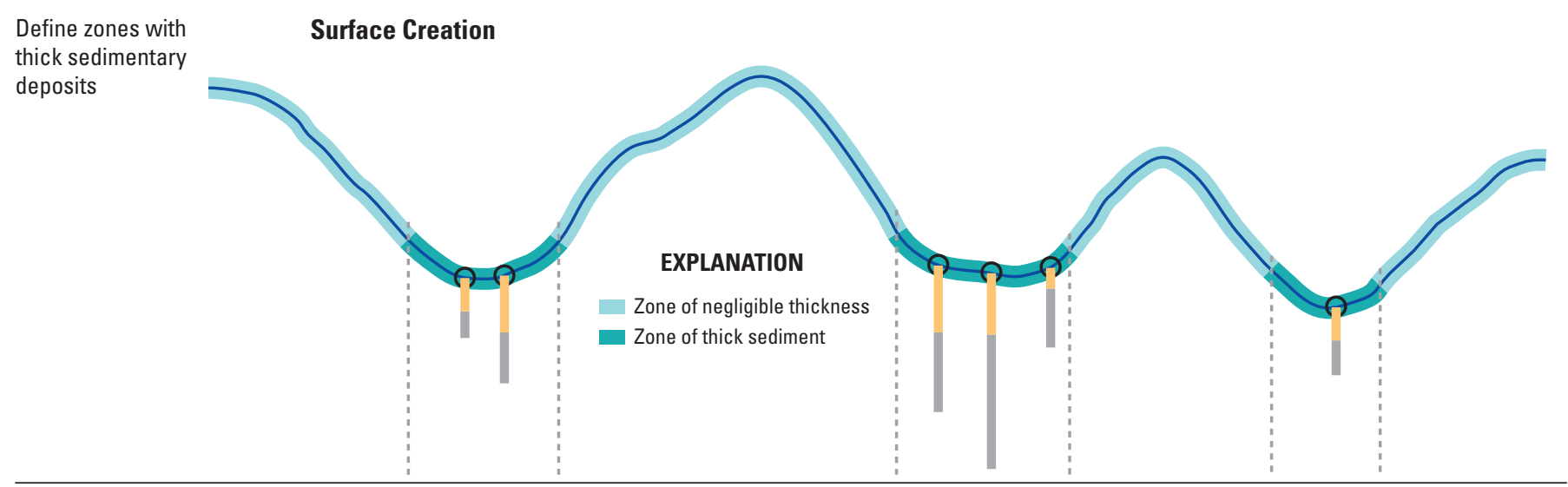

Step 6 - Regional

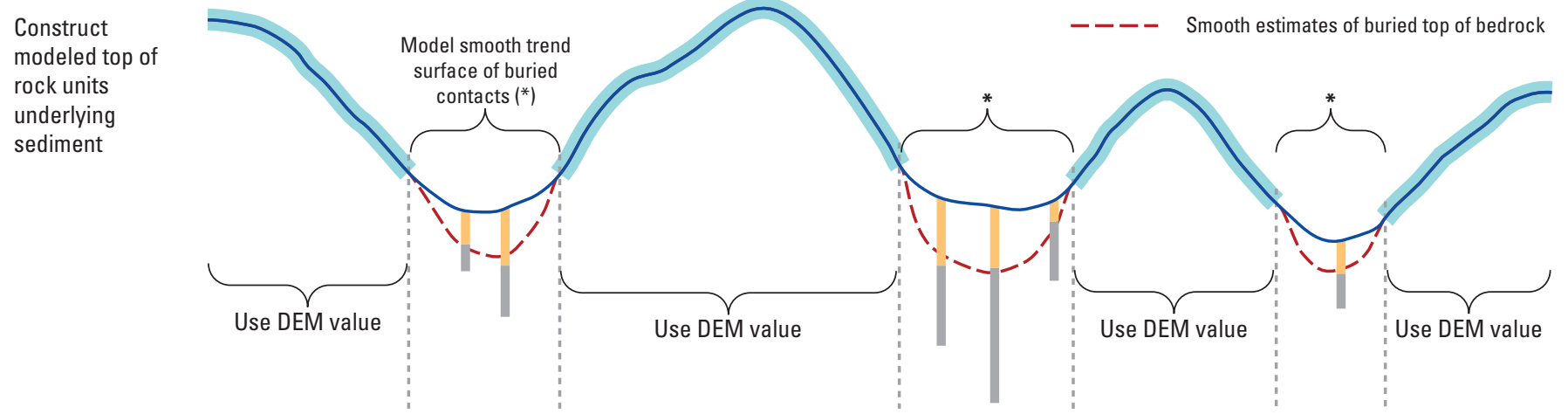

Result - Regional

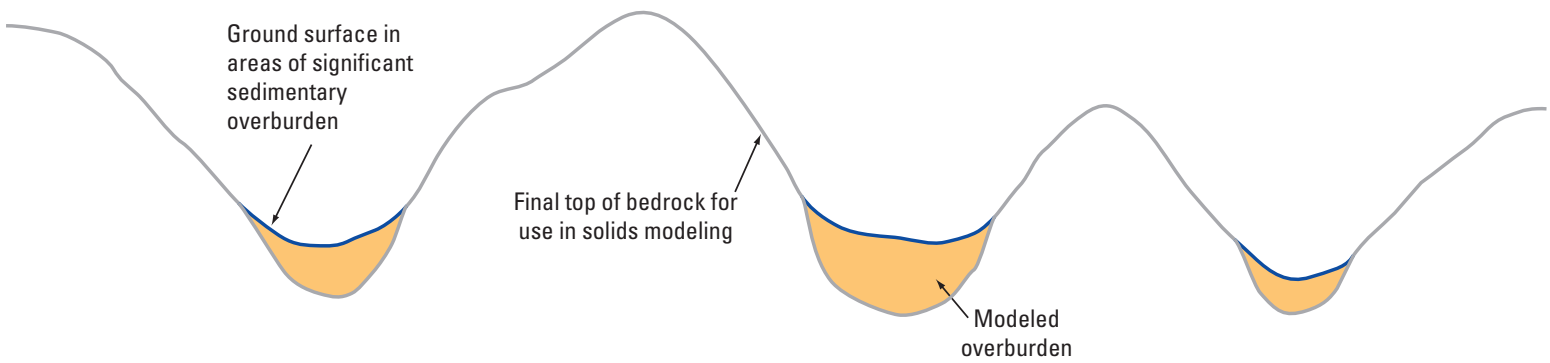

Figure 6.-Continued. 


\section{Using Thickness Maps for Quality Assurance and Model Revision}

After generation of a geologic model, the results are analyzed numerically and visually for fit to assess that the resulting geology is reasonable (fig. 3A). The previous sections describe generation of all surfaces necessary to create the model given the available data (fig. 1). However, the well data often do not provide data about deeper units because the purpose of most wells is to extract water from the uppermost productive zone permitted by law (fig. 7 "Reality"; productive aquifers are assumed to be present at each unit top). As a result, sampling is biased and, in the presence of geologic structure, trend modeling may result in undesirable artifacts (ig. 7, step 1, “modeled pinchout”). The thickness of the CRBG deposits is assumed to vary smoothly in space, generally thicker near the source of lava, and thinning distally. This pattern may be complicated by deposition onto faulted, folded, or eroded topography; however, anomalous thickening or thinning in the resulting model that is not explained by structure is assumed to be a numerical artifact resulting from trend surface generation.

If the resulting model is determined to be inadequate (fig. 7, step 2), then new trend surfaces are generated using additional guide points (fig. 7, step 3). In areas with little or no data available for deeper layers, guide points are generated by inference. Geologic contact elevations in wells are used to estimate underlying geologic contact elevations by subtracting estimated thickness of geologic units. Thickness values at each point are extracted from crude thickness trend maps that are developed using loess interpolation of thickness data. These new guide points are then added to the trend modeling dataset to ensure that model-generated thicknesses are consistent with the conceptual model. This process is repeated until the final model fits the conceptual model.

\section{Post-Processing of Model-Generated Units}

Because the modeling process uses the intersection of trend surfaces, the process may predict that a unit is present in a location where it is not known to be present. Two possibilities exist: (1) Either the unit does exist at the location, but has not been mapped or identified in a borehole, or (2) the unit is a numerical artifact associated with the modeling process. Most commonly, the numerical artifact is created as a result of using trend models that represent the average elevation of a surface, rather than the high points associated with erosion-resistant portions of the geologic deposit. This situation is analogous to the situation that created the isolated deposits on topographic highs shown in figure 5, and, again, the erroneously simulated unit has the same resulting pattern.

In order to remove the numerical artifacts for the bedrock layers, a post-processing filter was used to clean the final solids model. This filter removed portions of a model-generated layer if the portion of the layer was small, discontinuous, and not known to be present at that location. These isolated model artifacts are called orphans. The filter works by finding all locations where the unit was mapped or found in a well, and if no portion of the orphan is intersected by any of these locations, the orphan thickness is removed from that model-generated layer and added to the underlying layer. Generally, only small orphans are removed because thick portions of the model-generated unit tend to be connected to some location where the unit is known to be present, implying that the resulting geometry is geologically reasonable. Only a few large orphans were removed, consisting of Saddle Mountains Basalt in the northeastern part of the model area. This area was scoured by the catastrophic Missoula Floods (Richmond and others, 1965; Waitt and Thorson, 1983) and is mapped as being covered by loess deposits (fig. 1A). If any of the Saddle Mountains Basalt orphans were removed erroneously, then the orphans would be simulated as Wanapum Basalt (underlying unit), which is not problematic for the purposes of groundwater flow modeling.

\section{Modeling Major Sedimentary Interbeds}

In the modeling process, only two sedimentary interbeds are considered: the Vantage interbeds and the Mabton interbed. These deposits correspond to the two lengthy periods between depositions of the major CRBG formations. The Vantage interbeds lie between the Wanapum and the Grande Ronde Basalts, and the Mabton interbed lies between the Saddle Mountains and Wanapum Basalts. Two modeling assumptions guide the analysis. The first modeling assumption is that the interbeds are preserved only where the lava overlies it. This assumption is a simplification and a reasonable hydrogeologic assumption, because where the overlying sediments are in contact with the interbed, the geologic and hydrogeologic properties are similar. The second modeling assumption is that sedimentary sequences that have been preserved as interbeds were thickest in low-lying areas. Because the CRBG lavas fill these low areas, thicker interbeds correspond to thicker deposits of the overlying basalt. Using this assumption, the thickness of the interbeds is generated as a function of distance between the overlying and underlying basalt unit tops (the combined thickness of the interbed and the overlying basalt unit).

\section{Modeling of Faults}

Several assumptions regarding faults were implemented to facilitate modeling. All faults are represented as vertical faults, and closely spaced, parallel faults commonly were simplified to a single fault for the interpolation. Faults that cut younger strata are assumed to cross-cut older strata, but if a fault in an older unit was not required to explain the distribution of younger deposits, then the fault was not used as an interpolation or group barrier for the younger units. For this reason, there are fewer barriers in the upper units during the final interpolation of each layer. 


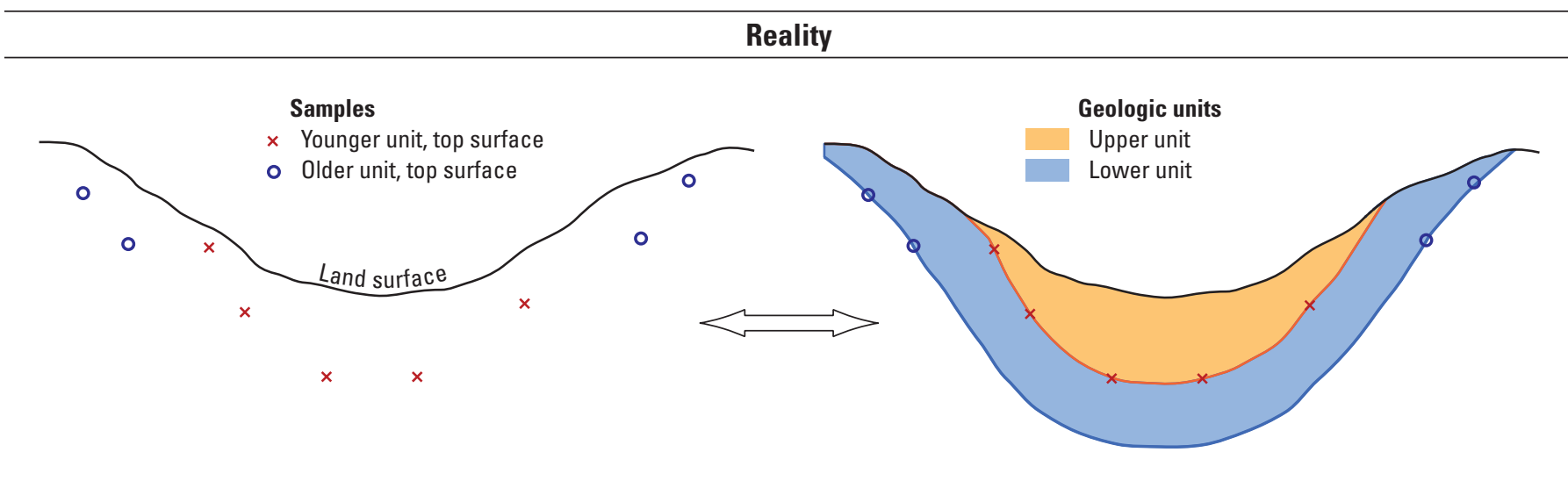

Step 1: Model surfaces and units from available data

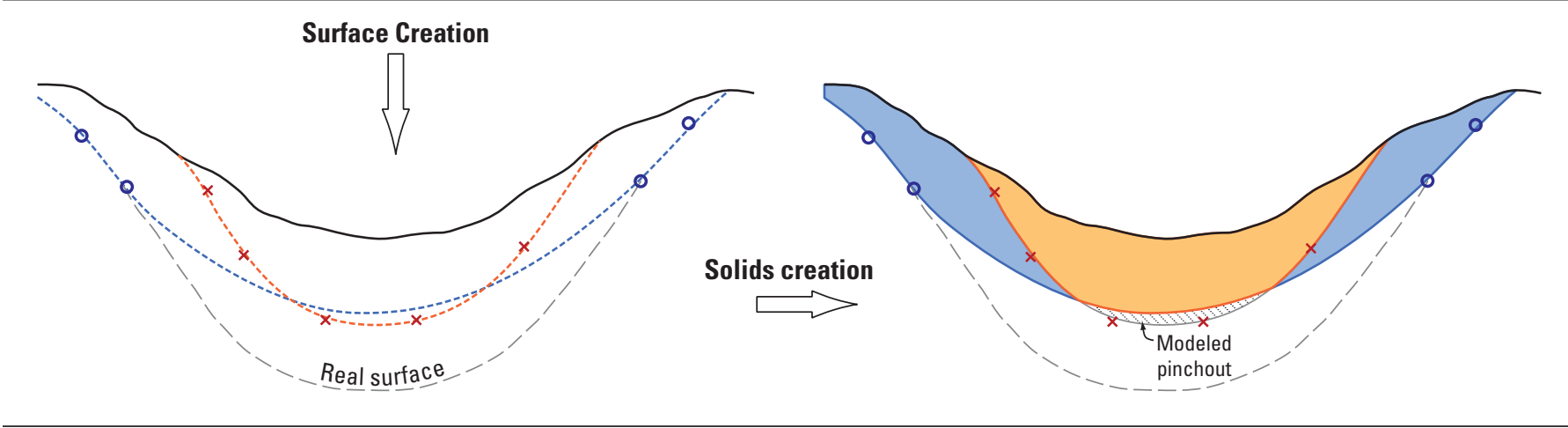

Step 2: Evaluate
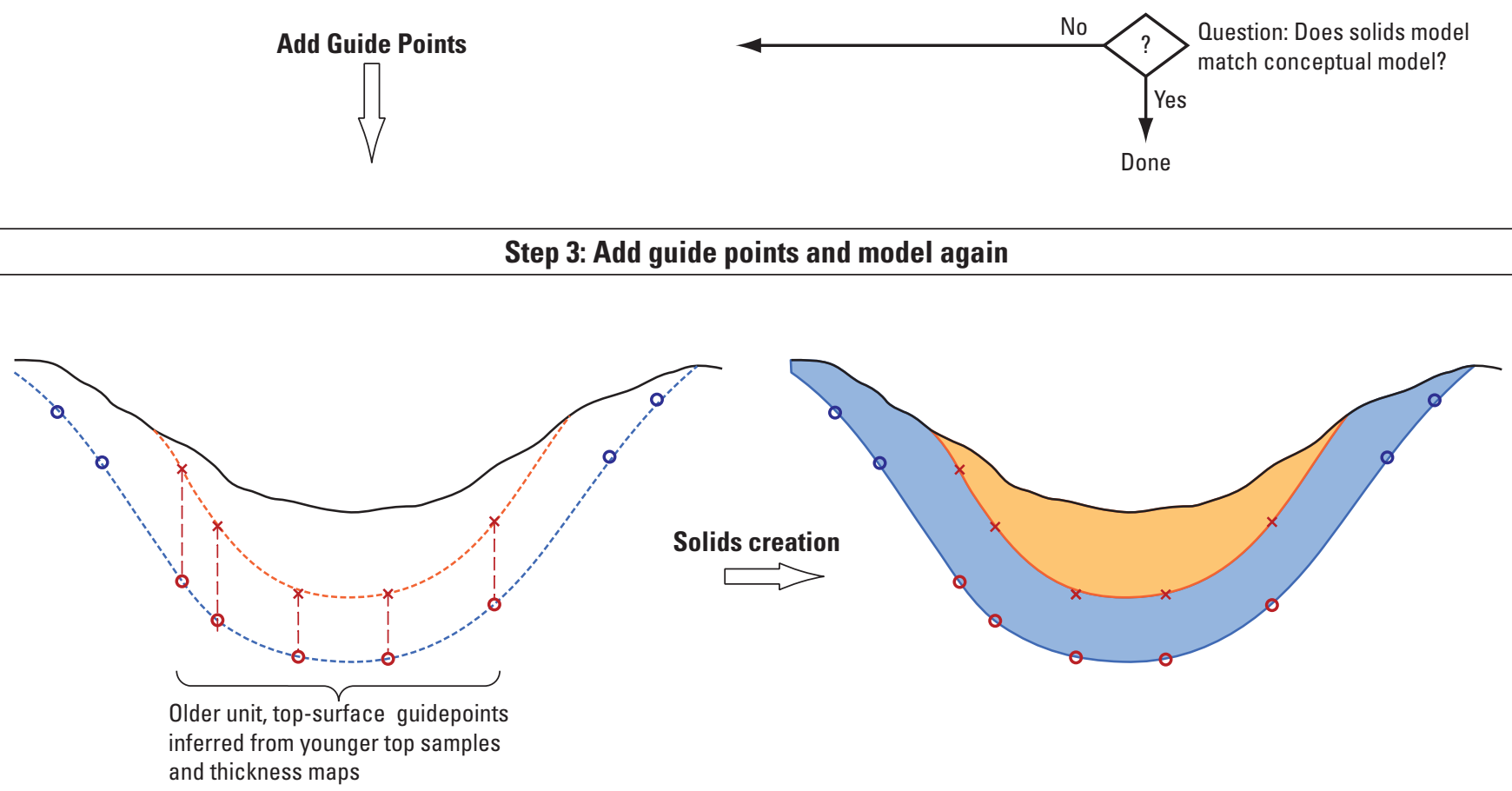

Figure 7. Addition of trend-derived guide points to model the geometry of deeper geologic units. 


\section{Data Sources}

For the CPRAS study, mapped surficial geology and well data sources that have a classification scheme sufficient to identify the major geologic model units were used. Rather than selecting a subset of the "best" data for an exact match, all data were used in the investigative process, and data were removed from the dataset only when the data point was shown to be nonrepresentative to such an extent that it resulted in significant bias that skewed the results. If only a few data are substantially different from a larger set of proximal data and no reasonable geologic explanation, such as a fault, explains the difference, then the outlier data are removed. All other data, including suspect data, are retained, and uncertainty and error are quantified.

For the work by Kahle and others (2009), a well dataset was prepared, a simplified geologic map was compiled, and a generalized map of hydrogeologic units and generalized hydrogeologic sections was constructed (Kahle and others, 2009). These data have been supplemented and reinterpreted for the current work. The well data were supplemented as described in section, "Well Data." Compilation and further simplification of the geologic map and the extraction of geologic information from the map for interpolation is described in section, “Geologic Map."

\section{Well Data}

All relevant sources of data should be considered when formulating or updating a geologic model. For this reason, the 2,523 wells used by Kahle and others (2009) were supplemented with data published by others, resulting in a significantly larger set of 13,226 wells with relevant lithologic picks (fig. 1B). For non-USGS studies (Leek, 2006; Lindsey and others, 2007; and Tolan and others, 2007), data were used as published. All USGS data were reviewed, and the datasets were rectified wherever studies had conflicting picks for stratigraphy. Lithologic picks for wells made in the more recent study were assumed to be correct where they differed from picks from earlier studies, subject to the assumption that newer USGS interpretations took the older data into account when reinterpreting the data. USGS study wells [RASA wells updated by Kahle and others (2009), Yakima study wells (Jones and others, 2006; Jones and Vaccaro, 2008), and gas resources assessment wells (Wilson and others, 2008)] were supplemented with any additional wells from the USGS NWIS database (U.S. Geological Survey, 2009b) for which the thickness of the Overburden unit was estimated.

\section{Geologic Map}

If a geologic contact shown on a surficial geology map is representative of the top of a map unit, then the topographic elevation along that line represents the elevation of the top of the geologic unit. Furthermore, in areas where the geologic unit is exposed and not significantly eroded, those elevations also represent samples of the pre-erosional top of unit that may be used to interpret relational geometries of geologic units. The map-view relationships of geologic units used for this work are shown in figure 1A. These units are simplified (fig. 2) even further than was done by Kahle and others (2009).

The foundation for the model is a simplified geologic map of the Columbia Plateau (Kahle and others, 2009), which was further simplified by grouping all CRBG units older than the Wanapum Basalt into the Grande Ronde Basalt unit (fig. 2). These units include the Grande Ronde, Picture Gorge, Prineville, and Imnaha Basalts. On the basis of location, most undifferentiated Miocene age basalts appear to be one of these older units, so these undifferentiated units also were grouped into the Grande Ronde Basalt unit. All sedimentary overburden units also were grouped for the geologic model.

Given these simplifications, the only sizable areas not defined lithologically for the model (fig. 1A) are mapped as Quaternary volcanic deposits. These data were not used in the model because of the limited areal extent, and because the modeling process will assign reasonable geologic and hydrogeologic properties to these locations during modeling of the sedimentary Overburden unit. If these deposits occur in lowlands near wells with thick sedimentary deposits, then the deposits likely overlie the sediments and will be simulated as having subsurface flow properties of sedimentary deposits. Otherwise, the unit will be represented as one of the Columbia River Basalts and flow properties will be those consistent with lava.

Mapped surficial geology contact lines that represent tops of units were converted to point data by sampling the land-surface elevation at closely spaced points along the line. Because the line is a smooth line traversing undulating terrain, the elevation along the contact varies. It was assumed that on average the line is correct, so a local median value was extracted as the best estimator of elevation along the line. Sample frequency is arbitrary, because the geologic contact line may be sampled as often as desired. The key consideration when selecting surficial geology sample frequency is that the final trend model should be influenced by all available data. If surficial geology is sampled too frequently, then the influence of well points is diminished because there are fewer well points. This bias is partly offset by the tri-cube weight function used by loess when well samples are far from surficial geology points, but is a larger problem when wells are near mapped geologic contacts. A trial-and-error approach was followed, and a final ratio of about 1:10 of wells to surficial geology points was selected, allowing a good fit to both wells and surficial geology. This estimate of the ratio does not hold in every interpolation group for the piecewise interpolation. Some groups have little well data, whereas others have little or no surficial geologic outcrop data for the unit being interpolated. 


\section{Other Interpreted Data}

With an estimated maximum thickness of approximately $16,500 \mathrm{ft}$ near the center of the basin, few wells penetrate the entire thickness of the Columbia River Basalts over much of the Columbia Plateau. In order to estimate the top of the Older Bedrock unit for the entire model area, well data were supplemented with thickness estimates made by Reidel and others (2002) (see section, “Using Thickness Maps for Quality Assurance and Model Revision" ).

\section{Digital Surfaces, Thicknesses, and Extents of Geologic Model Units}

Model output includes model-generated surficial geology over 53,030 $\mathrm{mi}^{2}$ of the Columbia Plateau and the extent of the CRBG within this area (fig. 8), elevation of top of CRBG units and the Older Bedrock unit (figs. 9A-D), and thickness of CRBG units and the Overburden unit (figs. 10A-D). Histograms (figs. 11A-D) and an example of the spatial distribution (fig. 12) of mismatch between the surfaces and data points (residuals) provide a measure of error between the model-generated surfaces and the supporting data, which can be used to estimate the probability of encountering each surface within a prescribed interval in a well. Cross sections through the model domain (fig. 13) were generated. The Mabton and Vantage Interbed unit data were analyzed, but known discontinuity and uncertainty made mapping of these units explicitly infeasible. Instead, general thickness relations were developed for these units.

All model-generated surfaces and thicknesses are stored in GIS grid format, with each square grid cell being $500 \mathrm{ft}$ on a side. The model-generated surficial geology shows the intersection of each of the model units with the land surface. The intersection of the extents of all CRBG units forms the model-generated extent of the CRBG (fig. 8), which shows good agreement with the mapped surficial geology (fig. 1A). The computed area of the model-generated CRBG polygon is $42,064 \mathrm{mi}^{2}$, which agrees well with the estimate of $44,000 \mathrm{mi}^{2}$ for the CPRAS by Kahle and others (2009).

Computed areas and extents for the model units generally compare favorably to the estimates of Kahle and others (2009). The Grande Ronde Basalt unit with a computed area of $41,866 \mathrm{mi}^{2}$ compares favorably to the estimated area of 42,000 $\mathrm{mi}^{2}$. It underlies almost all of the $42,064 \mathrm{mi}^{2}$ computed CRBG extent. The only areas not underlain by the Grande Ronde Basalt unit are at the model periphery, where intracanyon flows of younger CRBG rock overlie the Older Bedrock unit directly. The computed Wanapum area of $24,379 \mathrm{mi}^{2}$ also is close to the estimated area of $25,000 \mathrm{mi}^{2}$. The Saddle Mountain unit has a computed area of $11,668 \mathrm{mi}^{2}$, contrasting with the estimate of $8,000 \mathrm{mi}^{2}$. Contrary to the estimated extent of Kahle and others (2009), the geologic model predicts that many of the topographic highs on the Palouse Slope may be Saddle Mountains Basalt, which is supported to a limited extent by identification of this unit in drillers' logs and on geologic maps. Most of this area is geologically mapped as being mantled with sediment, so either interpretation is considered reasonable. Whether the rock is Wanapum or Saddle Mountains Basalt, a regional groundwater flow model likely will be insensitive to this distinction because the unit will be simulated as basalt either way. For the Overburden unit, the shapes of thick sedimentary sequences that are model-generated and estimated by Kahle and others (2009) are sufficiently different that the change in shape likely is more important for controlling groundwater flow and exchange with surface water than for estimating total area. For each unit, the model volumes are Grande Ronde $\left(31,273 \mathrm{mi}^{3}\right)$, Wanapum $\left(2,156 \mathrm{mi}^{3}\right)$, Saddle Mountains $\left(663 \mathrm{mi}^{3}\right)$, and Overburden $\left(244 \mathrm{mi}^{3}\right)$.

\section{Model-Generated Elevations of Tops of Units}

Each model-generated top of CRBG and Older Bedrock (figs. 9A-D) is exposed at land surface over part of the model area and buried over other parts. When the unit is buried, the model-generated top elevation is smooth, reflecting uncertainty in the model-generated trend surface. Contours show estimated elevations where buried. Where the unit is exposed at land surface, the elevation of the raster is the land-surface elevation resampled to the 500-foot grid. The Overburden unit is always at land surface (igg. 8), so no separate map of the top of this unit is provided.

\section{Model-Generated Thicknesses of Units}

Each model-generated thickness (igs. 10A-D) was computed as the difference between the unit top and the top of the uppermost underlying units. Whenever the top is at land surface, the top inherits the properties of the resampled DEM, resulting in thickness maps with significant rugosity. For this reason, only shaded maps (no contours) are provided. The top of the Older Bedrock unit is the lower bound of the model, so no thickness map is available for this unit. 


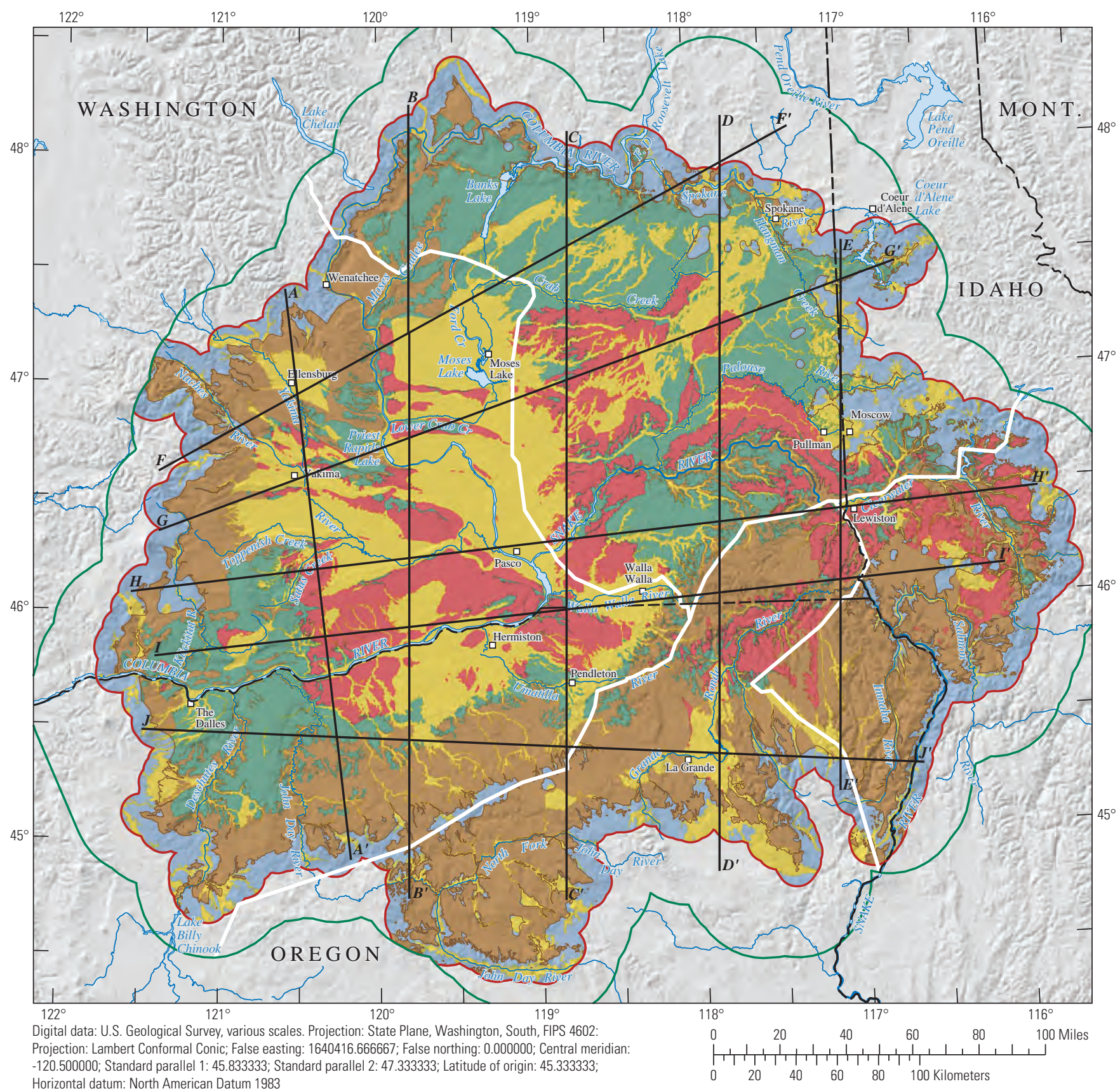

Horizontal datum: North Americo

EXPLANATION

Geologic units

Overburden (sedimentary)

Saddle Mountains Basalt

Wanapum Basalt

Grande Ronde Basalt

Older Bedrock
A A' Trace of cross-section shown in figure 13

Modeled extent of Columbia River Basalt Group

Data extent

Geologic model extent

Structural regions of the Columbia Plateau

Regional Aquifer System-Names shown on map at right

Figure 8. Model-generated surficial geology and Columbia River Basalt extent of the Columbia Plateau regional aquifer system, Idaho, Oregon, and Washington. 


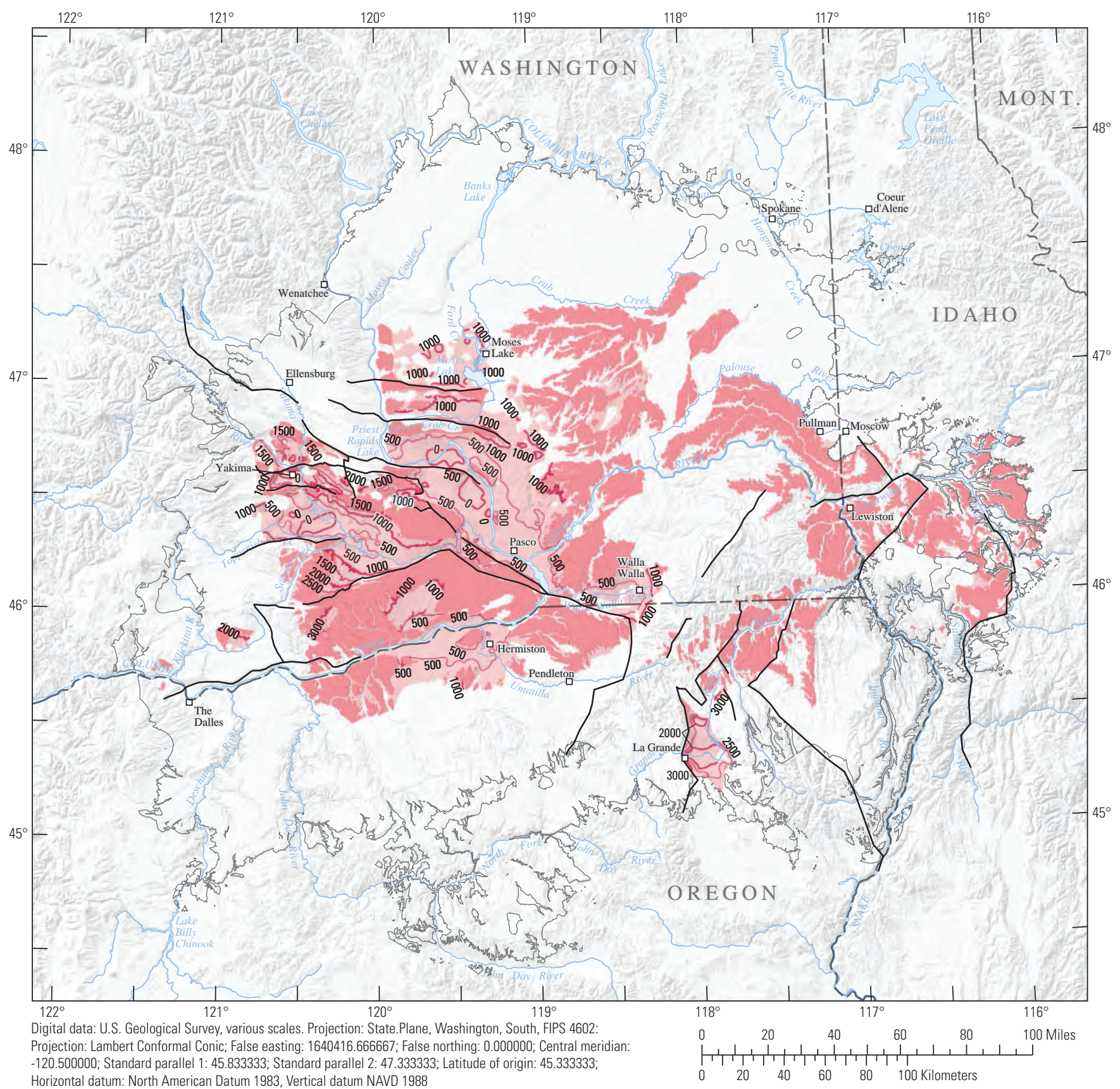

\section{A. Saddle Mountains Basalt unit.}

\section{EXPLANATION}

Saddle Mountains Basalt unit--top of unit
buried under land surface
Saddle Mountains Basalt unit-top of unit
at land surface
-1500 - Contour of top of Saddle Mountains
Basalt unit-units in feet above datum.
Contour line bold at 1,000-foot interval

Fault affecting distribution of the Saddle Mountains Basalt unit

Modeled extent of the Columbia River Basalt Group

Figure 9. Model-generated tops for the $(A)$ Saddle Mountains Basalt unit, $(B)$ Wanapum Basalt unit, $(C)$ Grande Ronde Basalt unit, and $(D)$ Older Bedrock unit, Columbia Plateau regional aquifer system, Idaho, Oregon, and Washington. 


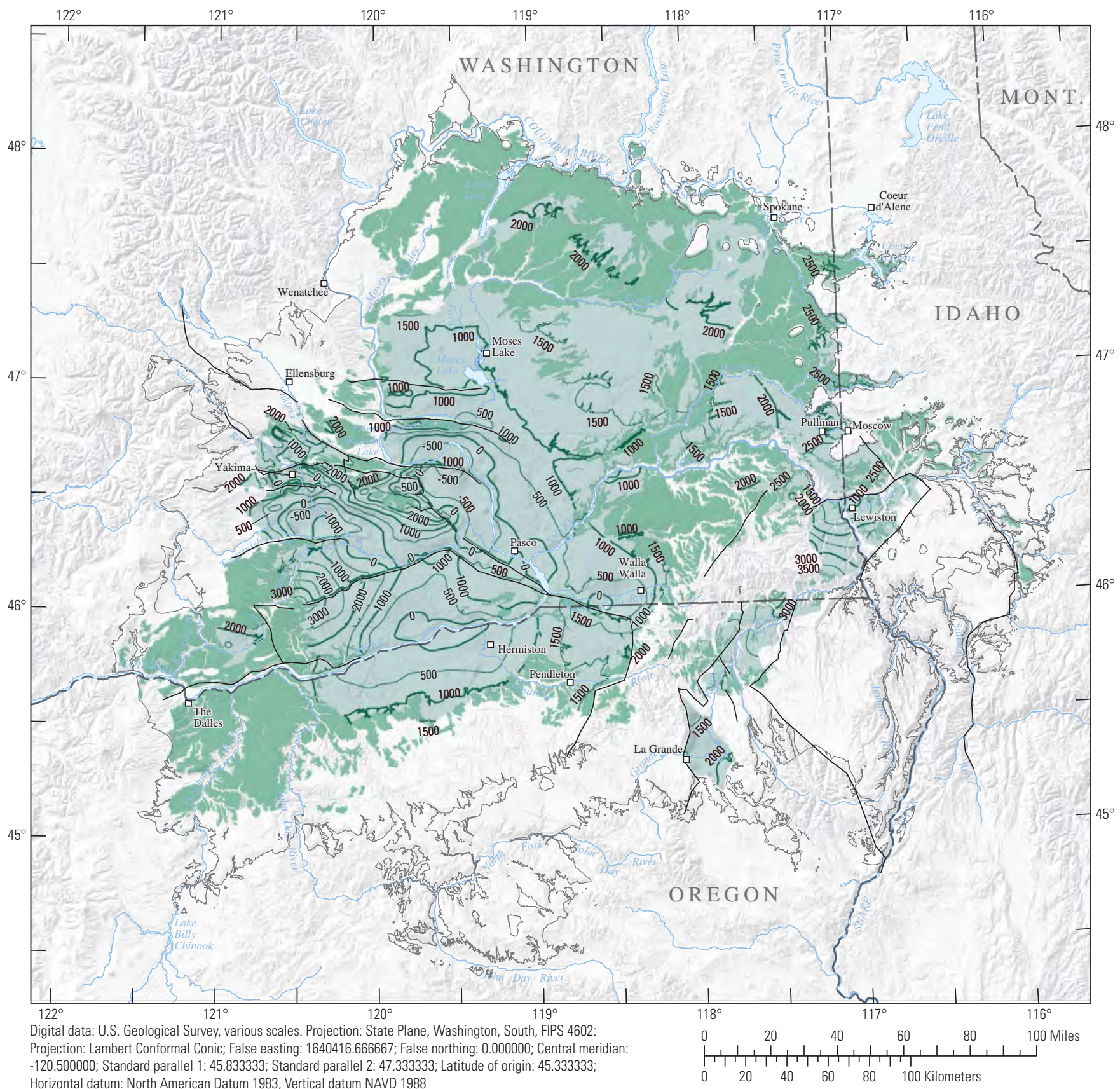

\section{B. Wanapum Basalt unit.}

\section{EXPLANATION}

Wanapum Basalt unit- top of unit buried
under land surface
Wanapum Basalt unit-top of unit at land
surface

Fault affecting distribution of the Wanapum Basalt unit

Modeled extent of the Columbia River Basalt Group

Figure 9.-Continued. 


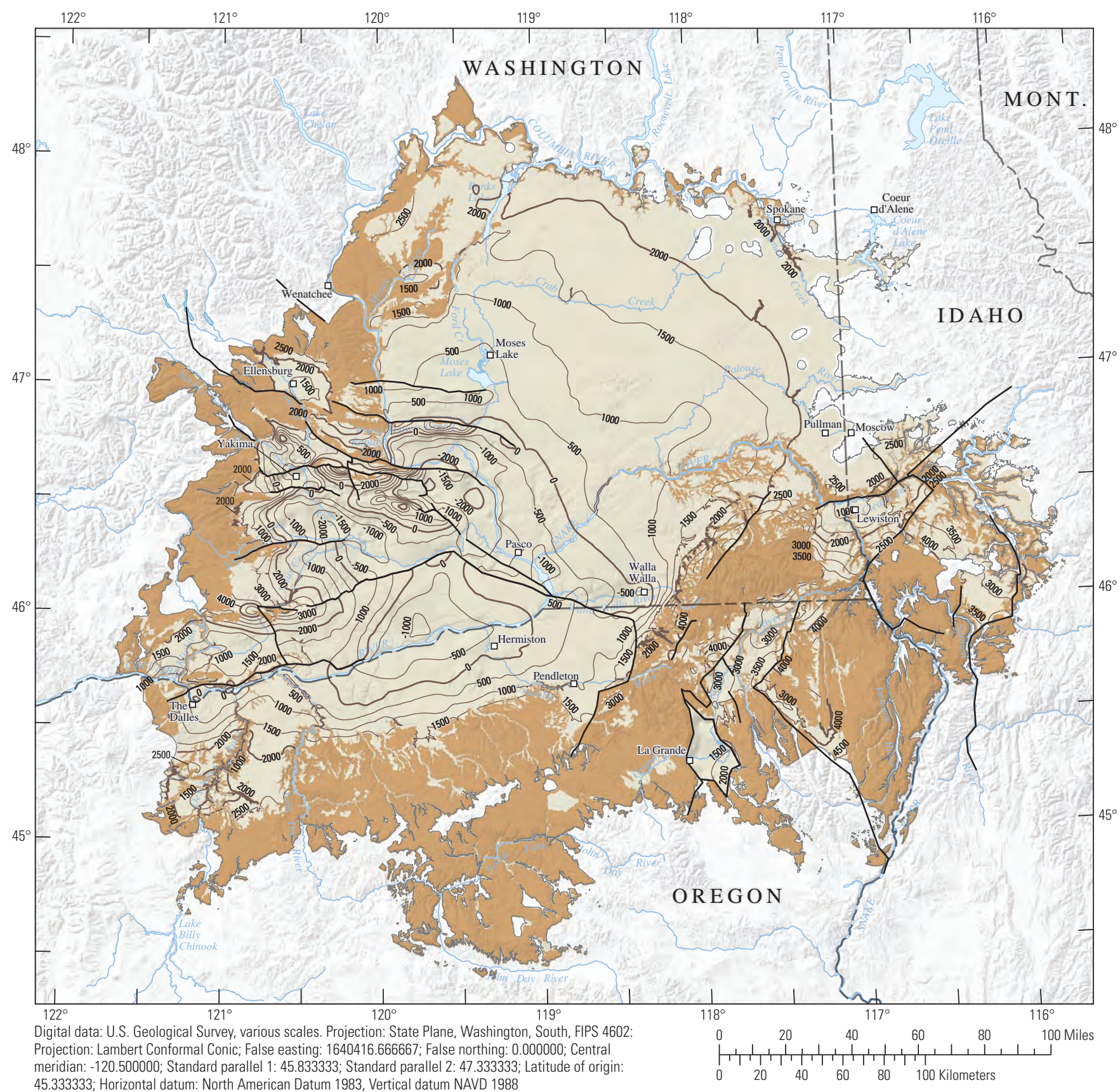

\section{Grande Ronde Basalt unit.}

\section{EXPLANATION}

Grande Ronde Basalt unit- top of unit buried under land surface

Grande Ronde Basalt unit—-top of unit at land surface

- 1500 - Contour of top of Grande Ronde Basalt unitunits in feet above datum. Contour line bold at 2,000-foot interval
Fault affecting distribution of the Grande Ronde Basalt unit

\section{Modeled extent of the Columbia River} Basalt Group

Figure 9.-Continued. 


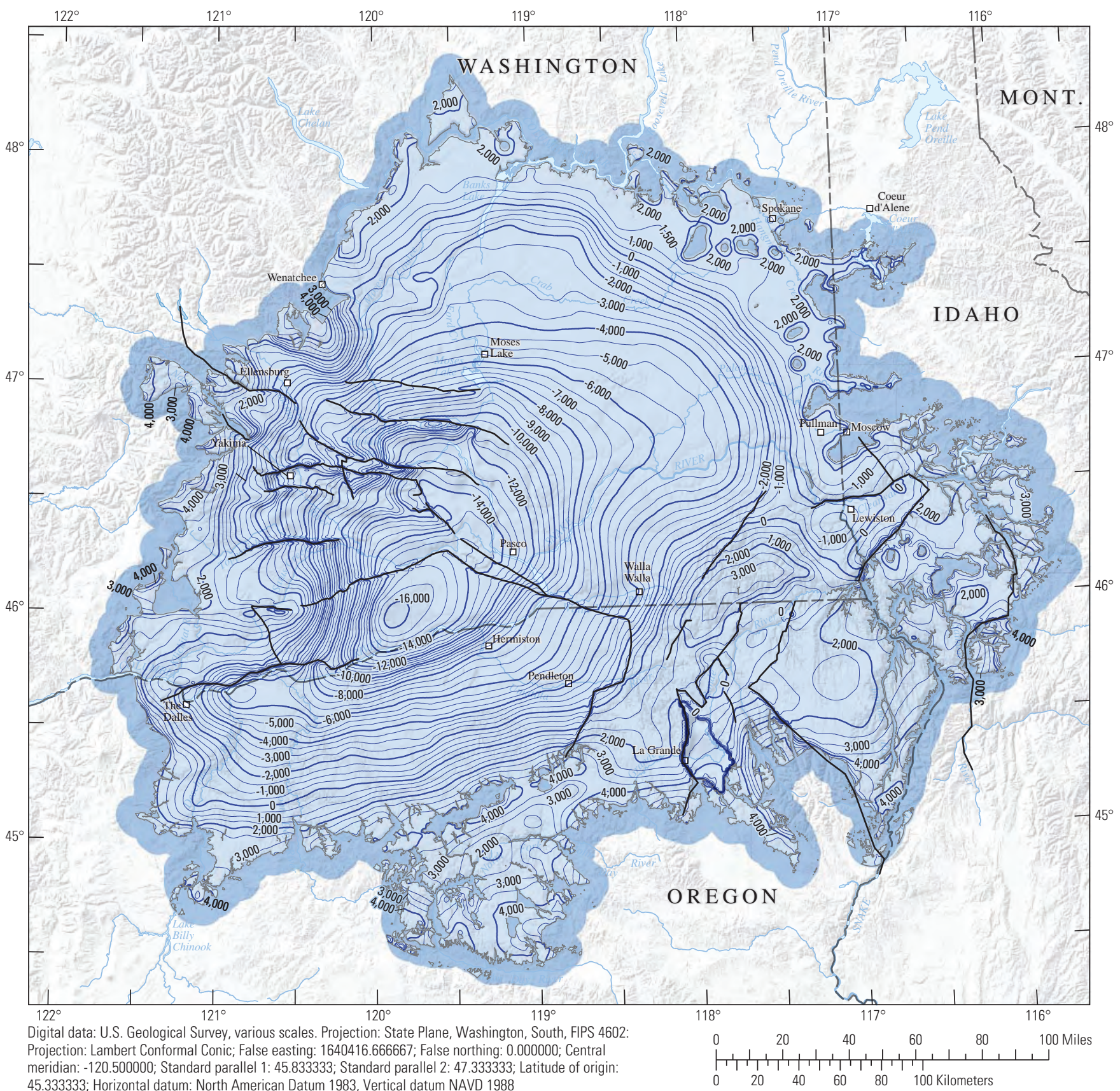

D. Older Bedrock unit.

EXPLANATION

Older Bedrock unit- top of unit buried under land surface

Older Bedrock unit—-top of unit at land surface

$-2,000$ - Contour of top of Older Bedrock unit-units in feet above datum. Contour line bold at 2,000-foot interval.
Fault affecting distribution of the Older Bedrock unit

Modeled extent of the Columbia River Basalt Group

Figure 9.-Continued. 


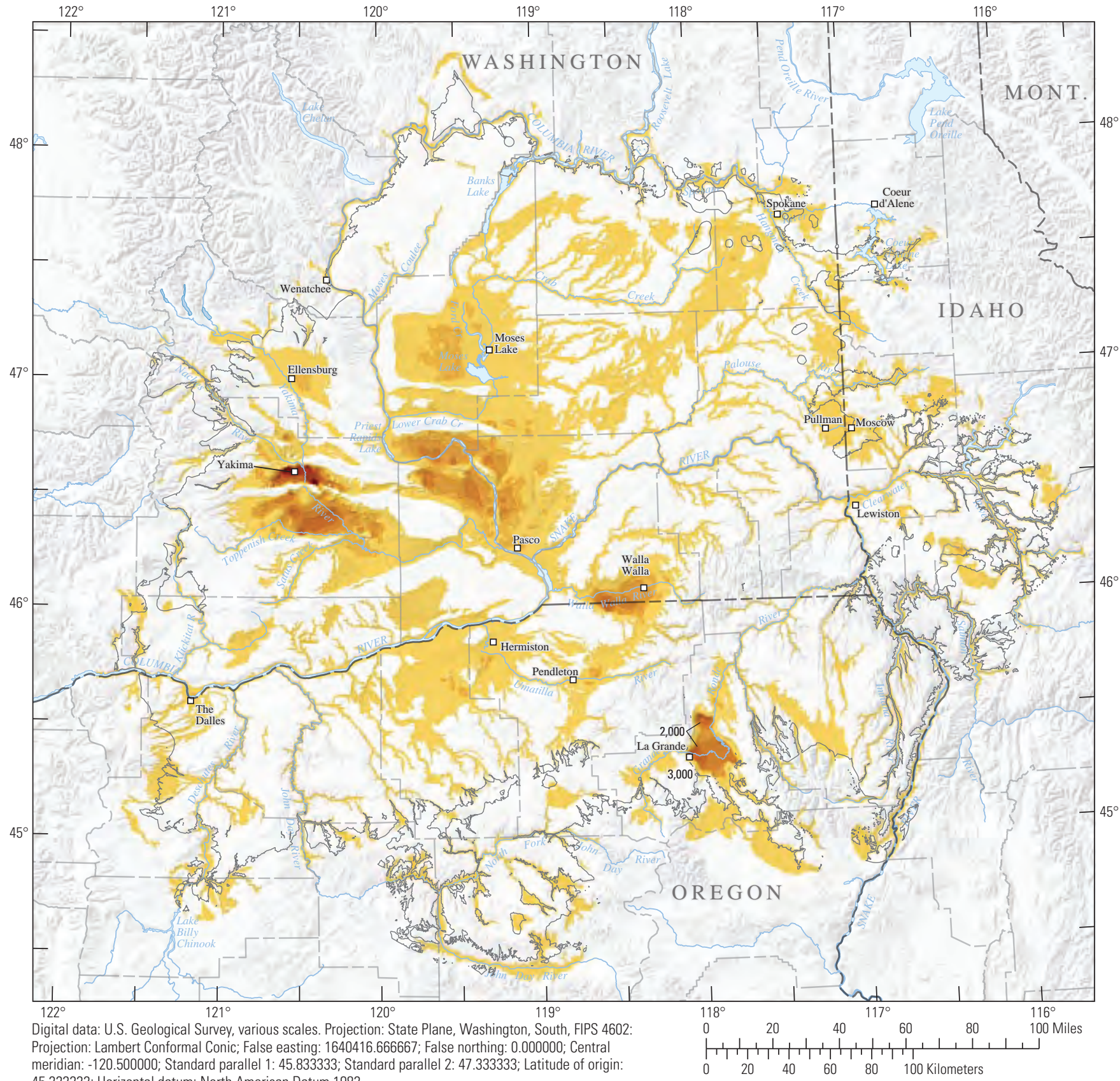

A. Overburden unit.

\section{EXPLANATION}

Thickness of Overburden (sedimentary)
unit, in feet
0
400
800
1,200
1,600

\section{Modeled extent of the Columbia River Basalt Group}

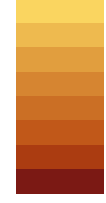

Figure 10. Model-generated thicknesses for the $(A)$ Overburden unit, $(B)$ combined Saddle Mountains Basalt and Mabton Interbed units, $(C)$ combined Wanapum Basalt and Vantage Interbed units, and $(D)$ Grande Ronde Basalt unit, Columbia Plateau regional aquifer system, Idaho, Oregon, and Washington. 


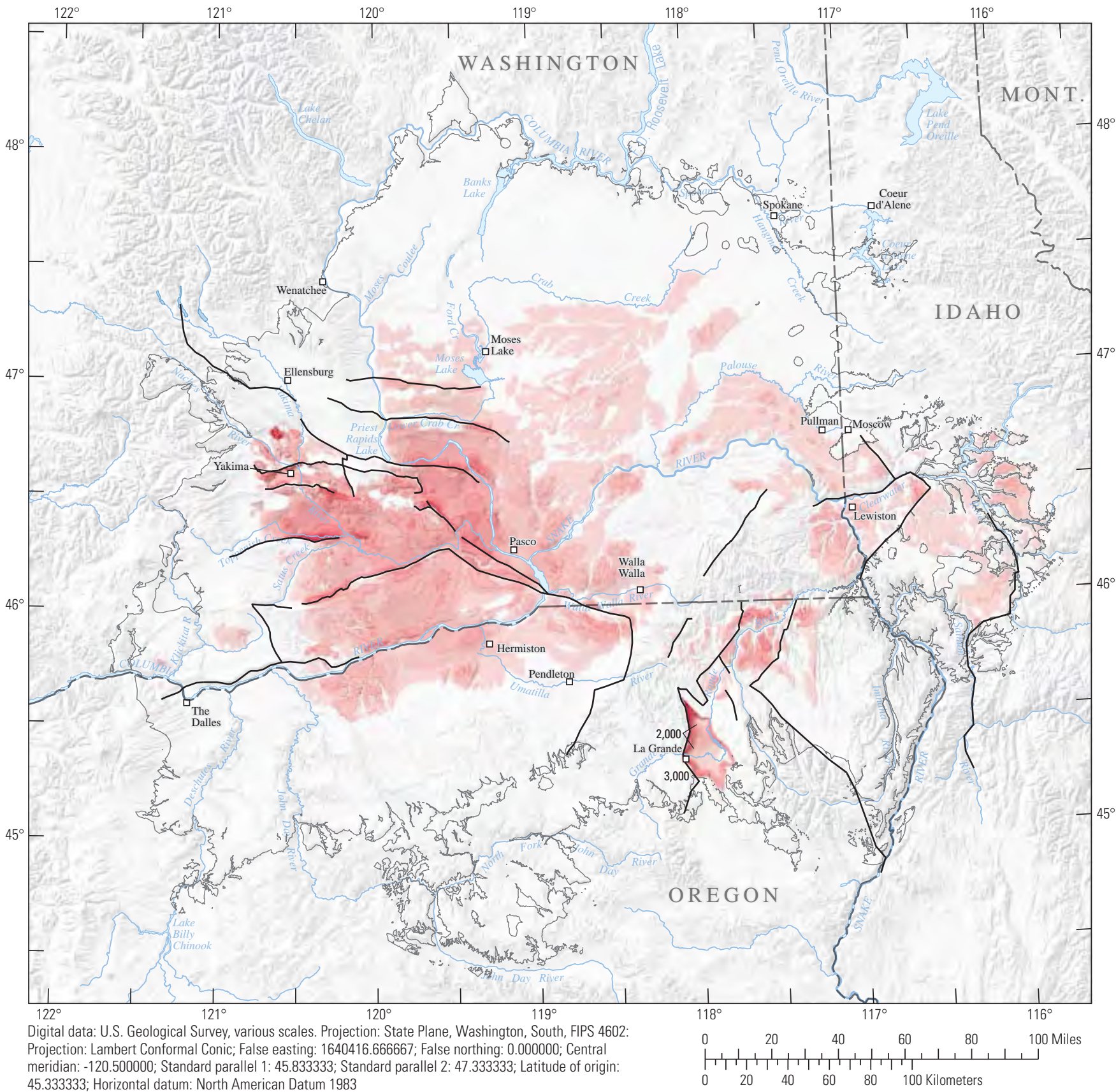

\section{B. Combined Saddle Mountains Basalt and Mabton Interbed units.}

Combined thickness of Saddle Mountains Basalt and Mabton Interbed units, in feet

400

800

1,200

1,600

2,000

\section{EXPLANATION}

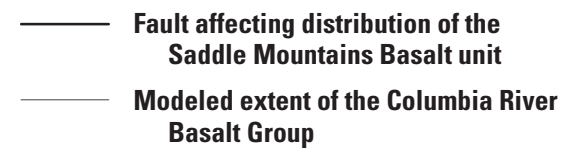

Figure 10.-Continued. 


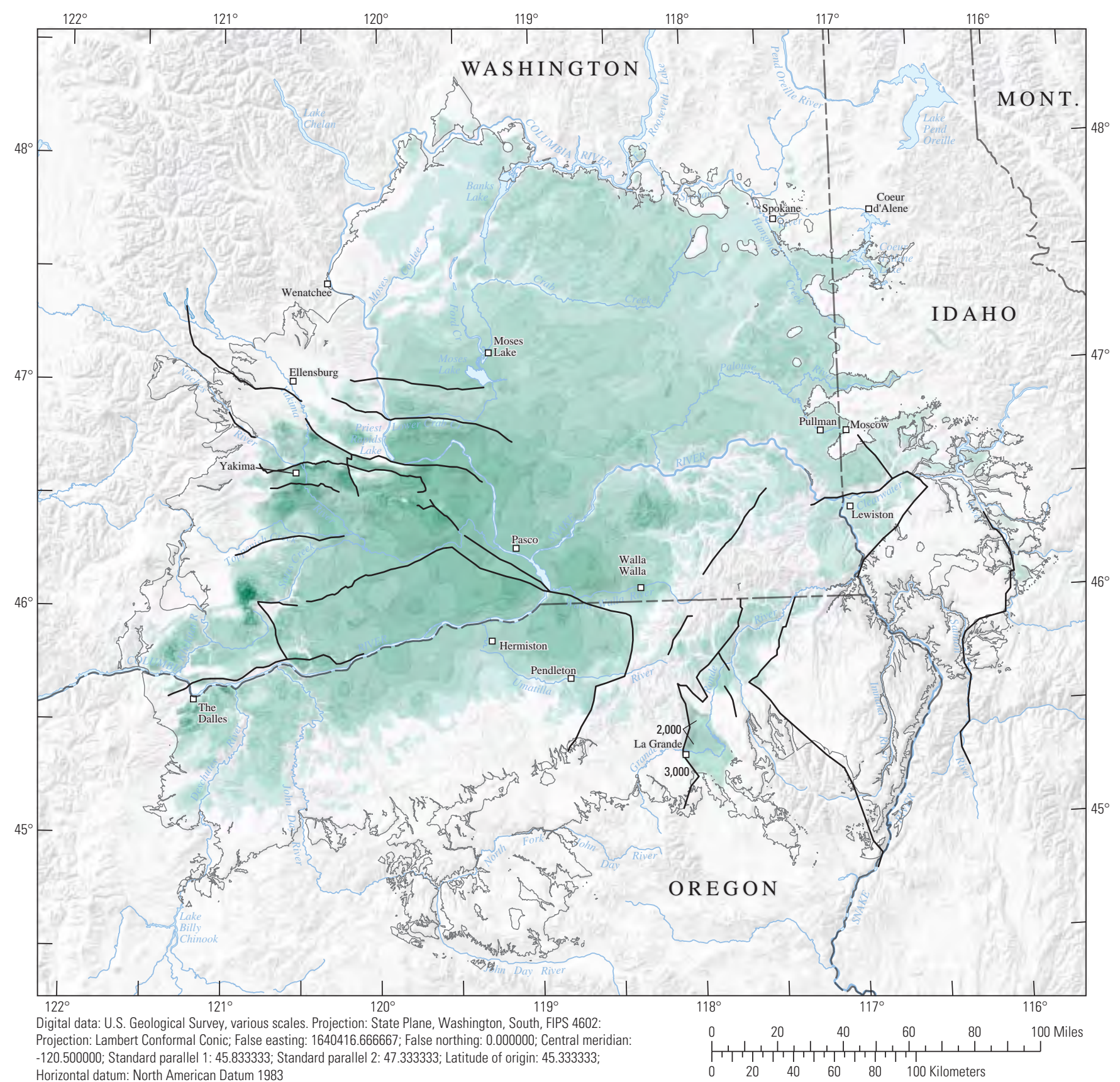

C. Combined Wanapum Basalt and Vantage Interbed units.

$\begin{gathered}\text { Combined thickness of Wanapum } \\ \text { Basalt and Vantage Interbed units, } \\ \text { in feet }\end{gathered}$
0
400
800
1,200
1,600
2,000

\section{EXPLANATION}

Want affecting distribution of the Wanapum Basalt unit

Modeled extent of the Columbia River Basalt Group

Figure 10.-Continued. 


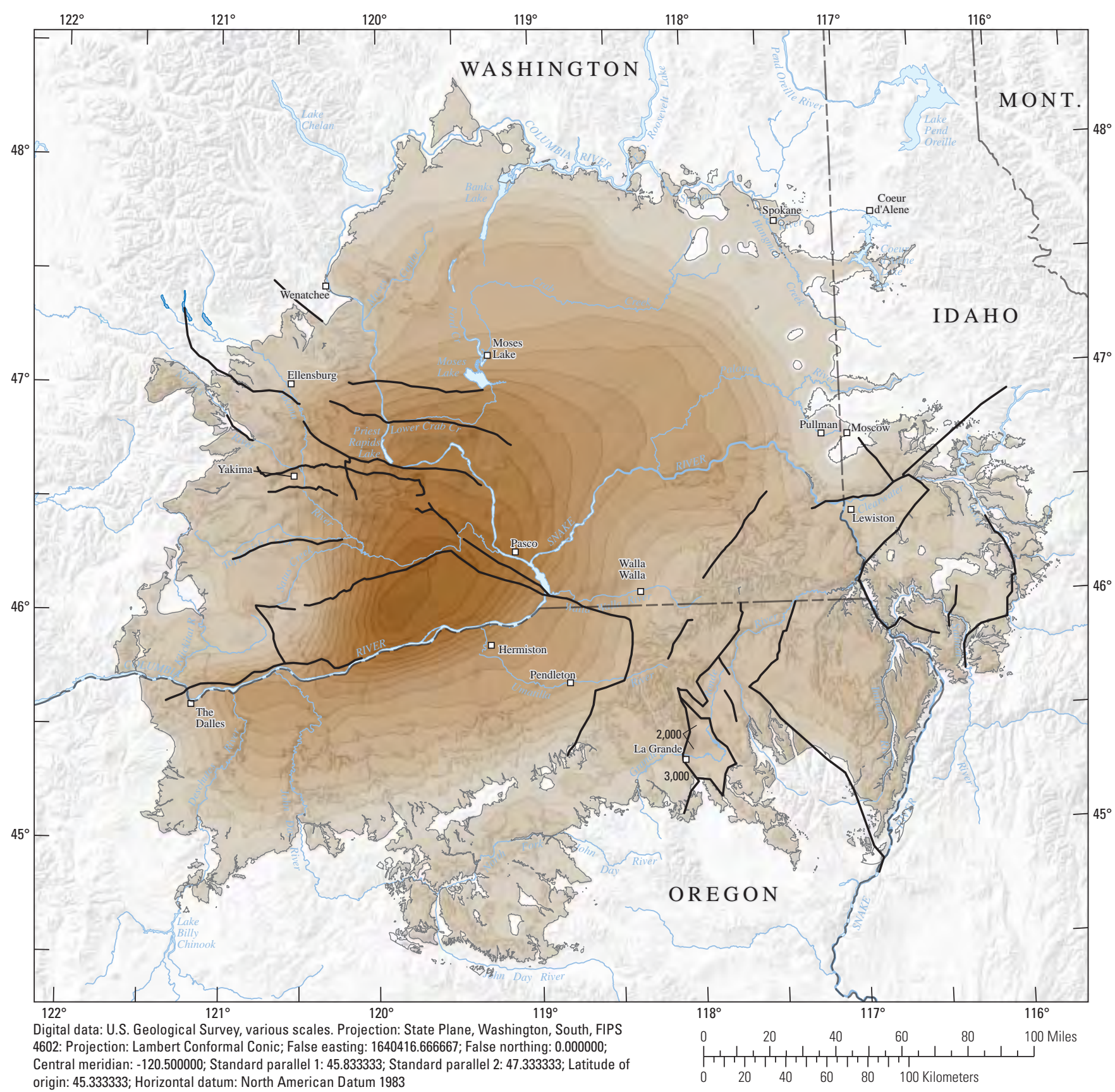

D. Grande Ronde Basalt unit.

\section{EXPLANATION}

Thickness of Grande Ronde Basalt unit, in feet
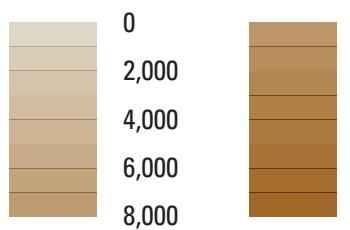

8,000

10,000

12,000

14,000

16,000

\section{Fault affecting distribution of the} Grande Ronde Basalt unit

Modeled extent of the Columbia River Basalt Group

Figure 10.-Continued. 


\section{Evaluation of Fit}

The well and geologic data were compared to the final surfaces by computing the difference between the unit top elevation from the data and the elevation predicted by the model. This difference, called a residual, is positive if the data are higher than the model surface and negative if the data are lower than the model surface. The model surface is a good estimator of the data if the residuals are random and there is no spatial bias. These properties imply that the median, mean, and mode of the residuals are all approximately zero, the residuals are symmetrically distributed around the mean, and there are no persistent spatial trends in residuals. The histograms for the Columbia River Basalt units (figs. 11A-C) indicate that the trend model is a good estimator for these units, but there
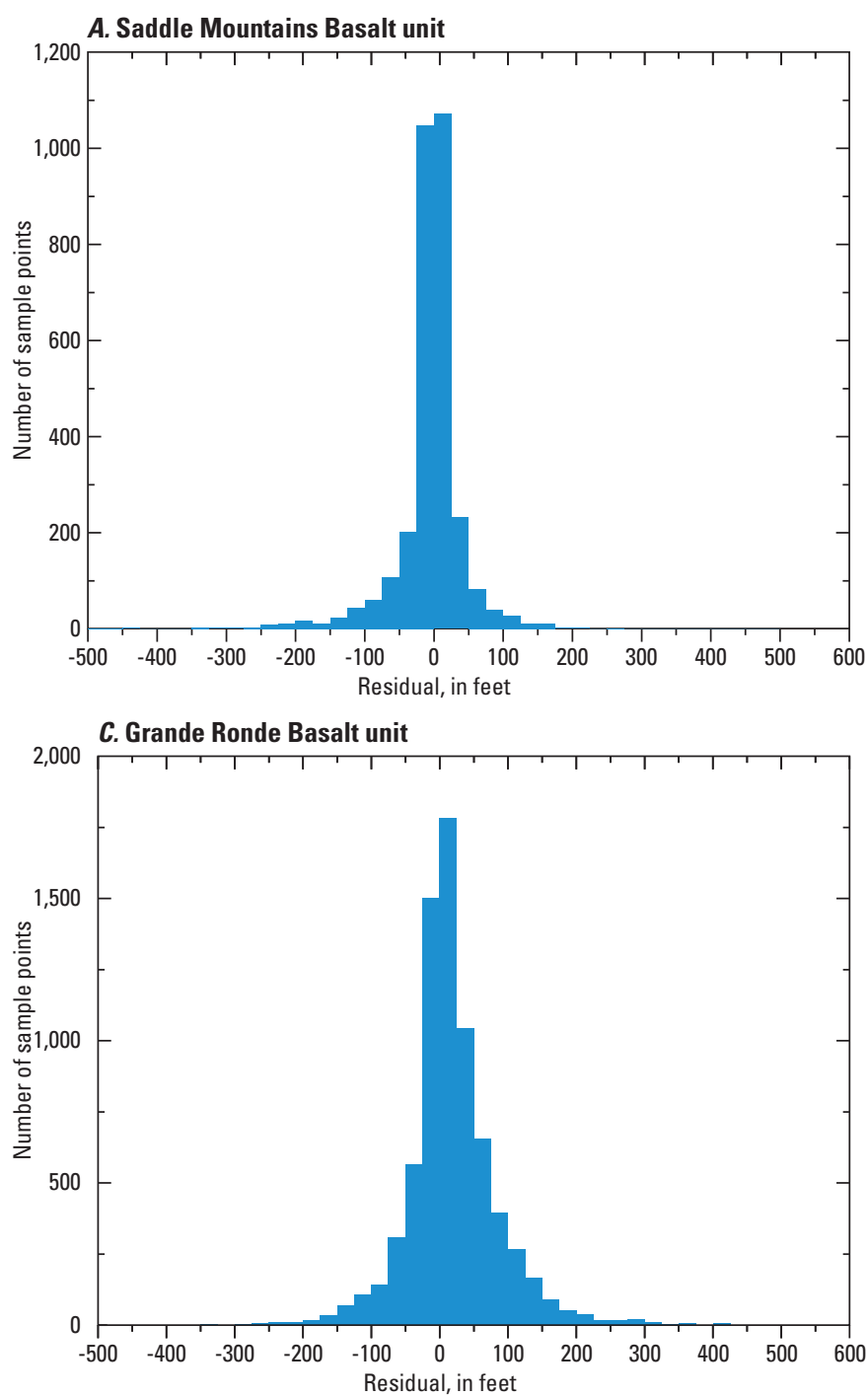

is some bias for the Older Bedrock trend surface (fig. 11D). Examination of the spatial distribution for all CRBG units indicates no strong spatial trends.

For example, the distribution for the top of Grand Ronde residuals (fig. 12) shows the model matches the data spatially. The top of Grande Ronde model elevation ranges from approximately $-2,200$ to $7,800 \mathrm{ft}$, with a total difference of about 10,000 ft. Most of the residuals are less than $100 \mathrm{ft}$ (less than 1 percent of the trend surface being represented) and have no strong spatial trends. The sparse data in the center of the map are supplemented with guide points to aid in constructing reasonable geologic geometries (see section, “Using Thickness Maps for Quality Assurance and Model Revision"), but the guide points are not used when computing residuals to assess model fit.
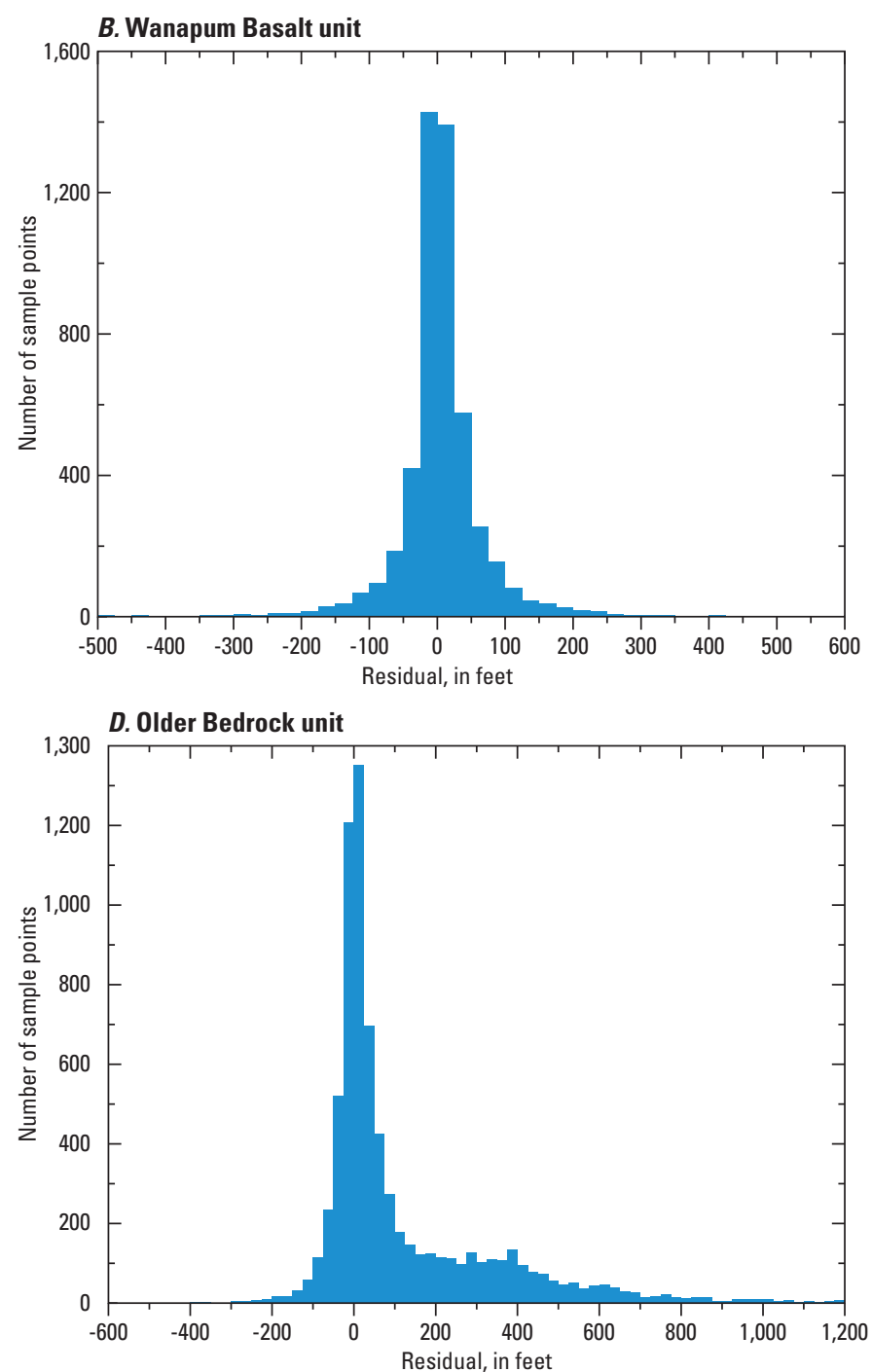

Figure 11. Residuals for the model-generated tops of geologic model units for the $(A)$ Saddle Mountains Basalt unit, $(B)$ Wanapum Basalt unit, $(C)$ Grande Ronde Basalt unit, and $(D)$ Older Bedrock unit, Columbia Plateau regional aquifer system, Idaho, Oregon, and Washington. 


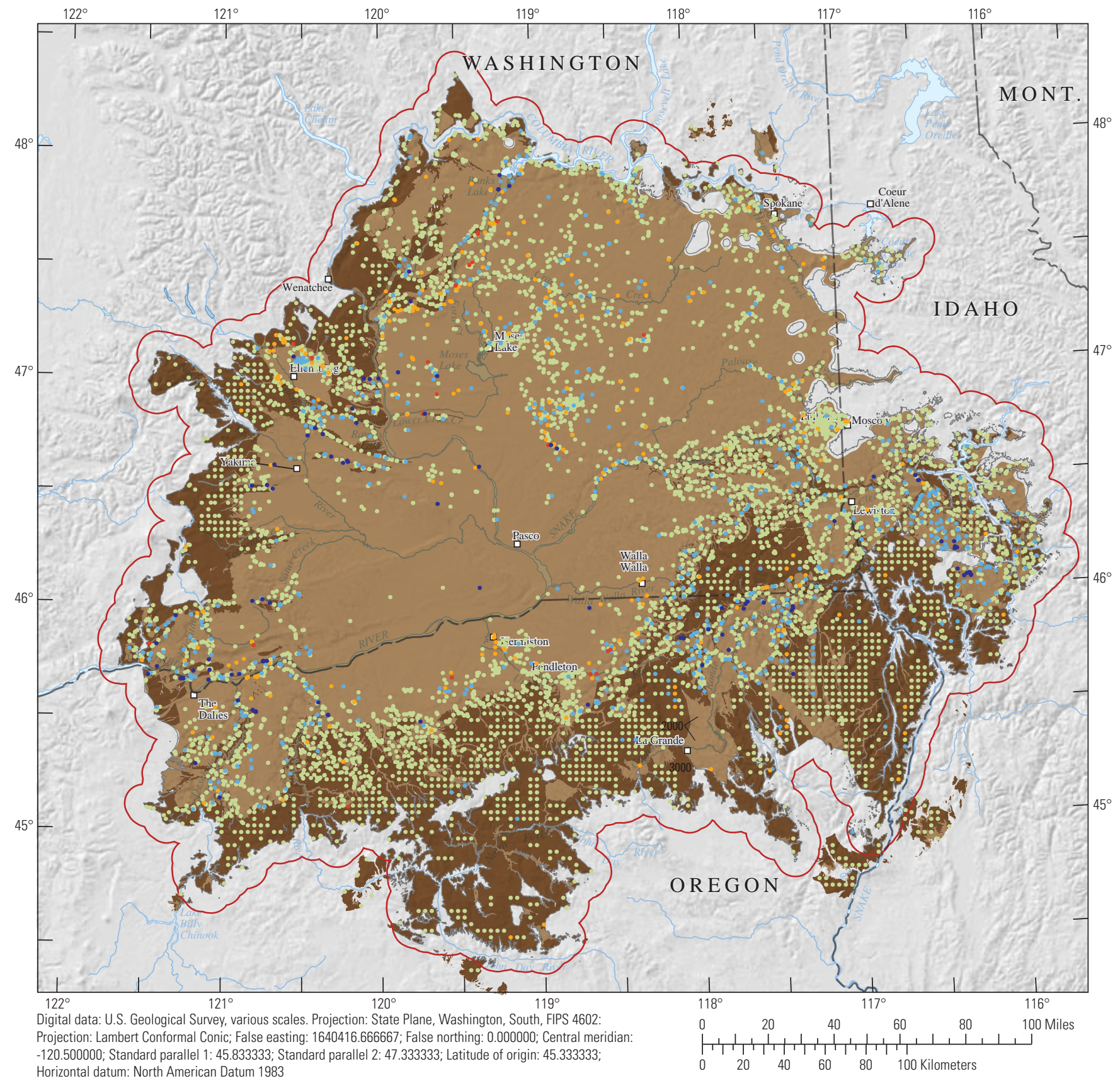

Horizontal datum: North American Datum 1983

\section{EXPLANATION}

$$
\begin{aligned}
& \text { Residuals for the modeled top of Grande } \\
& \text { - }-410.6 \text { to }-250 \\
& \text { - }-250 \text { to }-100 \\
& -100 \text { to } 100 \\
& \text { - } 100 \text { to } 250 \\
& \text { - } 250 \text { to } 3,157.8
\end{aligned}
$$$$
\text { Ronde Basalt unit-in feet }
$$

\section{Extent of buried Grande Ronde Basalt}

Extent of exposed Grande Ronde Basalt

\section{Geologic model extent}

Figure 12. Spatial distribution of residuals for the model-generated top of the Grande Ronde Basalt unit, Columbia Plateau regional aquifer system, Idaho, Oregon, and Washington. 
The top of Grande Ronde Basalt unit model fit was provided as the example because it shows how all of the different types of data were used together during the modeling process. The fits for the Saddle Mountains and Wanapum Basalt units are very similar to the fit for the Grande Ronde Basalt unit, but the Older Bedrock unit top has larger error and spatial bias (fig. 11D). The worse fit of the Older Bedrock unit is the result of increased uncertainty caused by little data being available over most of the model area, resulting in heavy reliance on inferred data points. Reidel and others (2002) provide a generalized map of total CRBG thickness that was used to infer the top of Older Bedrock using the modelgenerated CRBG unit tops. Use of this data increased the spread of the residuals, because well data did not always agree with the generalized trend.

The heavy tail of positive residuals on the histogram (fig. 11D) for the Older Bedrock unit is the result of most of the well picks for that unit (about 250 wells) being located near the northern and northeastern extent of the Columbia Plateau where deposition was dominated by intracanyon lava flows rather than by the sheet flows present over much of the study area. The Older Bedrock unit in this area forms topographic highs around which the CRBG lavas flowed and, even where it is buried, is expected to have highly variable elevation. Attempts were made to get a better fit to data in this area, but the result was that the CRBG units began pinching out anomalously. Data density is insufficient to define the true shape of the Older Bedrock top in this area.

Rather than forcing a better fit and causing geologically unreasonable pinchouts, the bias toward positive residuals was permitted in this area for two reasons. First, positive residuals imply that the modeled surface is lower than the data, but because wells commonly are drilled no deeper than necessary, more frequent encounters with the bedrock highs cause a bias of the data toward higher elevations. Sample bias toward the higher values indicates that the trend is lower than the data imply. Second, allowing the bias toward positive residuals facilitates the use of modeled geology as the foundation for a groundwater flow model. Allowing the biased residuals at the model periphery result prevents anomalous pinchouts of the overlying model unit, resulting in continuity of the model unit, allowing the possibility that this unit may transmit water during groundwater-flow simulation modeling. If sufficient groundwater-level data are available during the groundwaterflow simulation process, the degree of conductivity in this area will resolve itself.

The total elevation range of about 25,000 ft for the top of the Older Bedrock unit implies that the larger $500 \mathrm{ft}$ of error corresponds to about 2 percent, which still provides a good general representation of this unit. However, uncertainty in this trend surface elevation is more substantial than for the tops of the CRBG units because of the low density of data (less than 300 wells, with most representing only a small part of the study area).

In the absence of strong spatial trends in the residuals, the implicit assumptions underlying the kriging paradigm are satisfied. If local estimates of uncertainty are required, then kriging may be used as the exact interpolator for the residuals, so that the kriging variance would be an estimator of local uncertainty, allowing computation of error bars on interpreted surfaces. Furthermore, Sequential Gaussian Simulation may be used to construct stochastic realizations for use in other uncertainty assessment exercises as desired (Deutsch, 2002). More simply, because the mean value of the residuals is approximately zero, and assuming that the residuals are stationary (supported by absence of spatial trends), the trend surface and the distribution of residuals may be used to infer the likelihood that a contact is within any given range of elevations as supported by available local data. The estimate of contact elevation is more reliable if there are nearby wells where the unit has been identified. In locations where little data are available, the trend surface is the best estimator in an unbiased sense, but uncertainty increases with distance from data.

\section{Geologic Cross Sections}

The ten representative geologic cross sections in figure 13 show general trends and variability of geologic units across the CPRAS. The modeling assumption that all faults are vertical is best illustrated by cross sections passing through the Yakima Fold Belt structural region (fig. 8 and cross sections A$A^{\prime}$ and $B-B$ ' in fig. 13). 

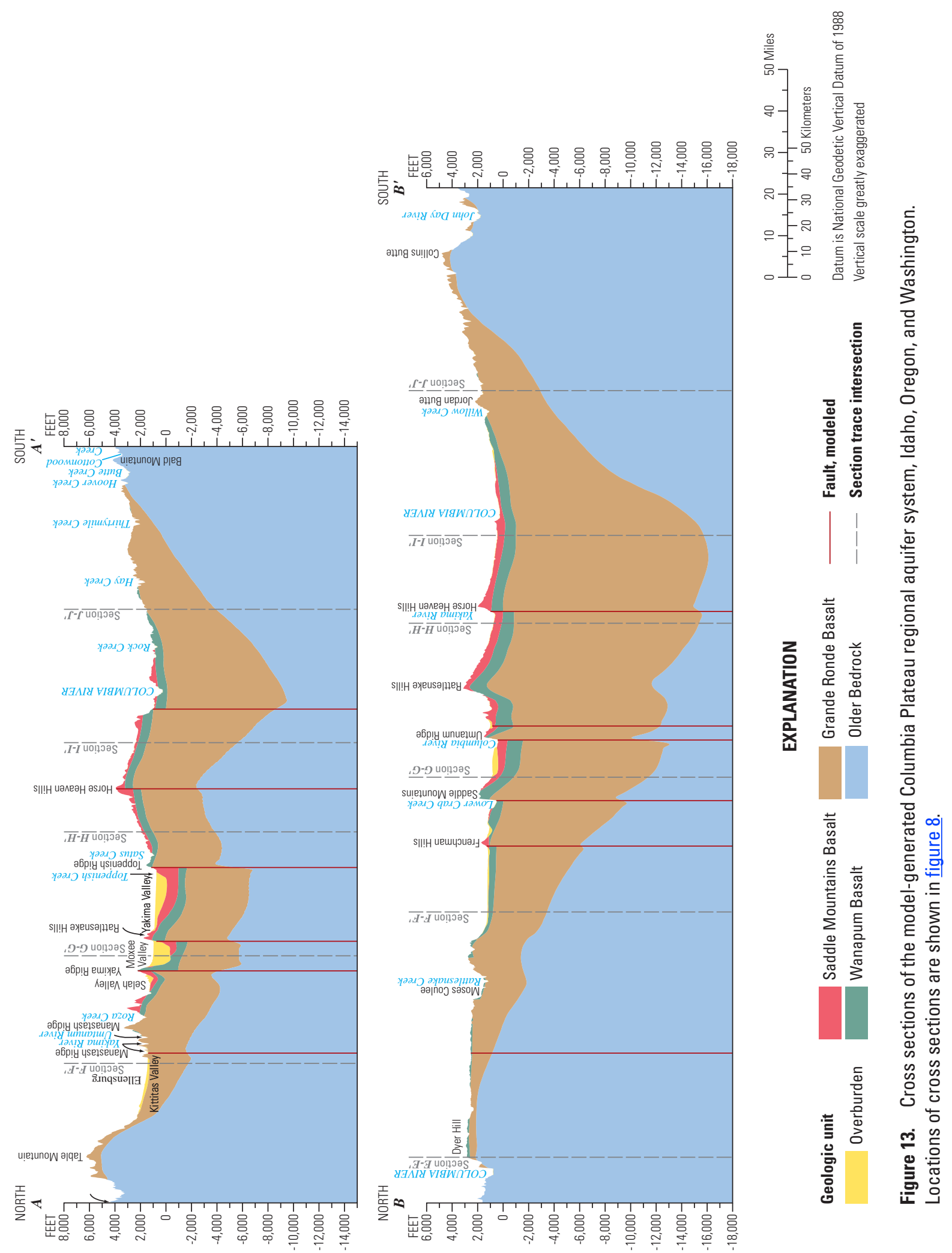

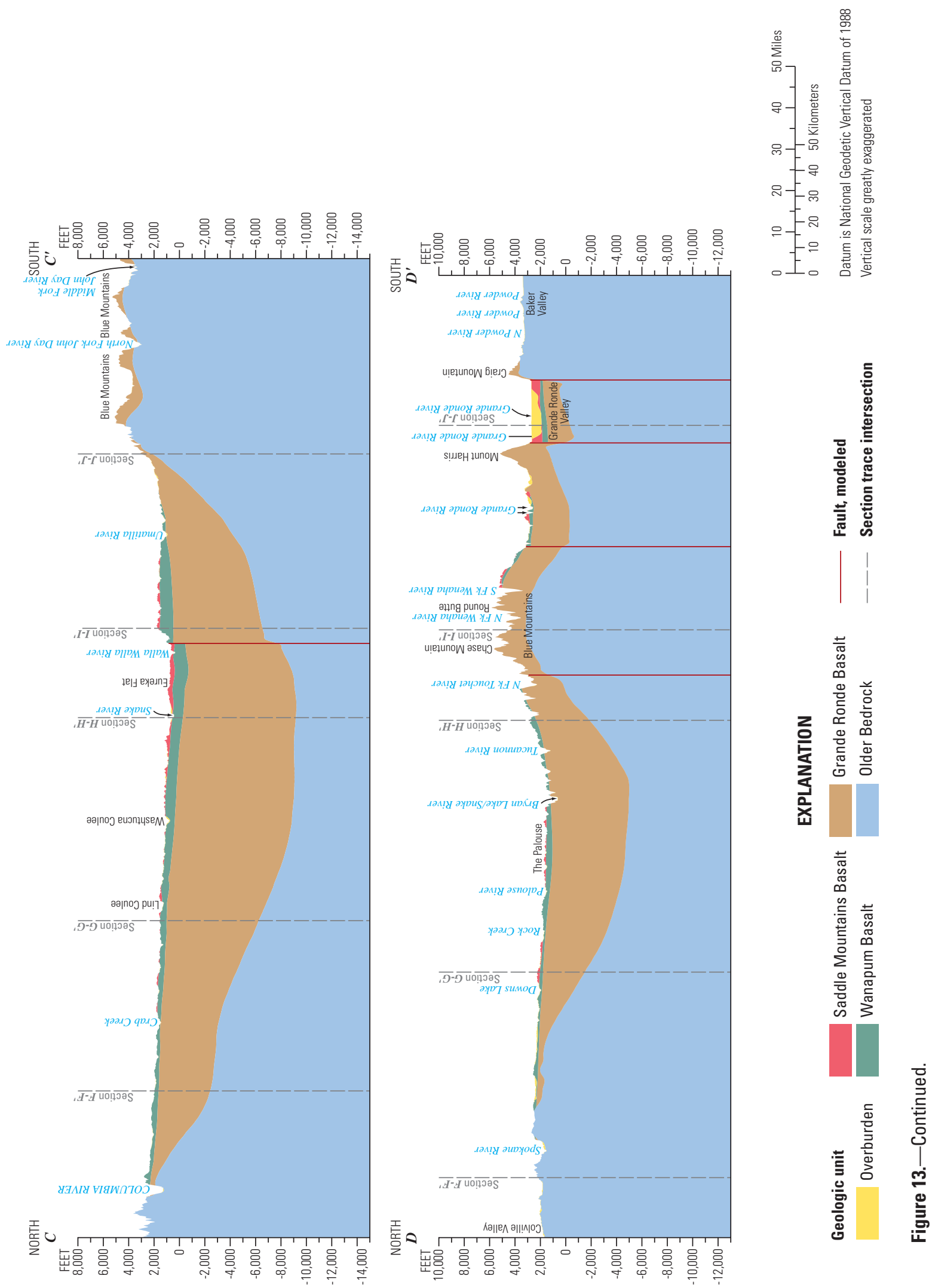

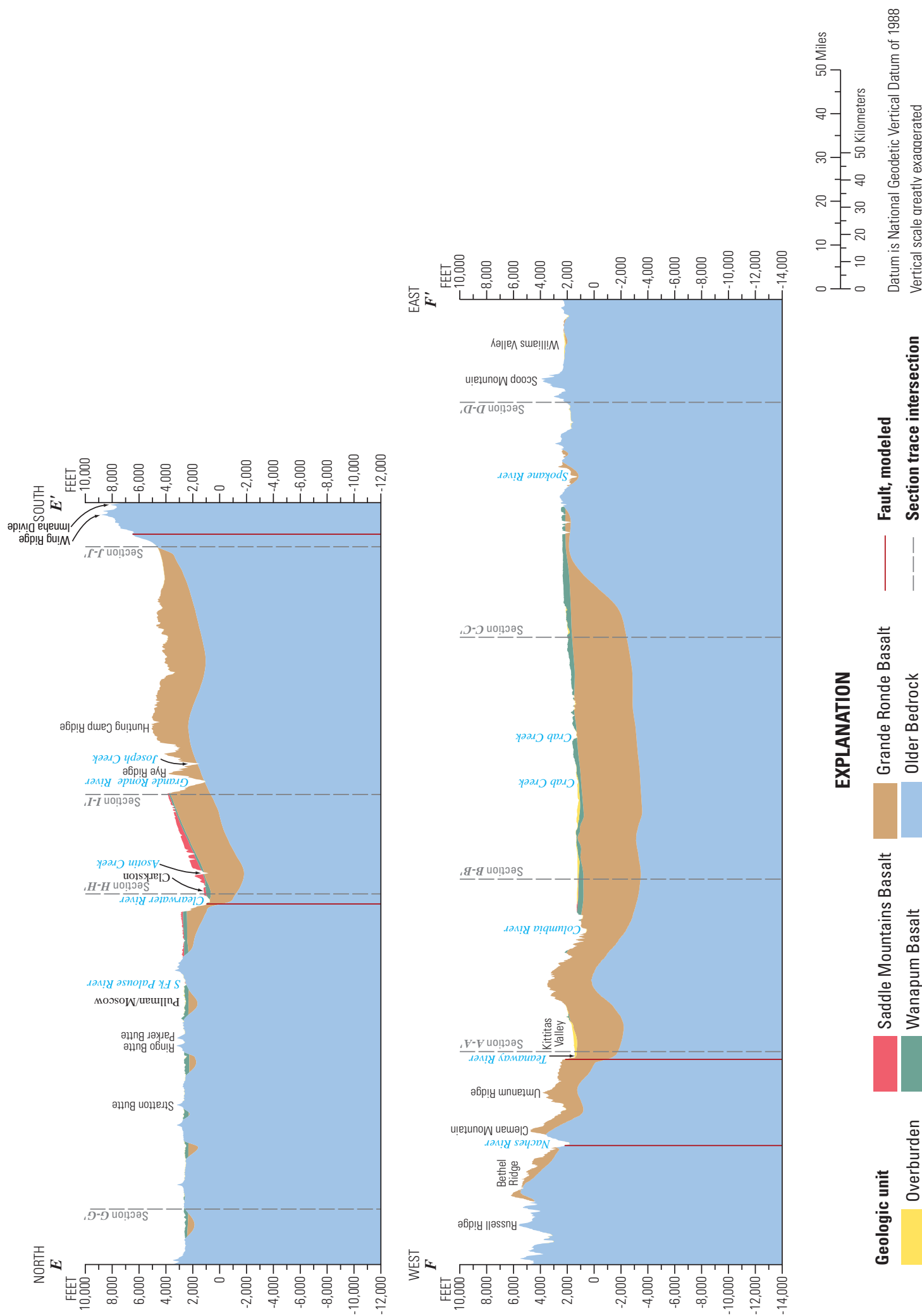

皆

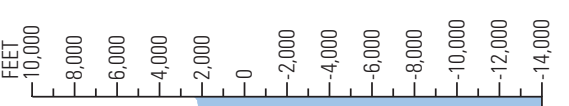

上。要

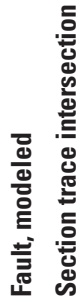

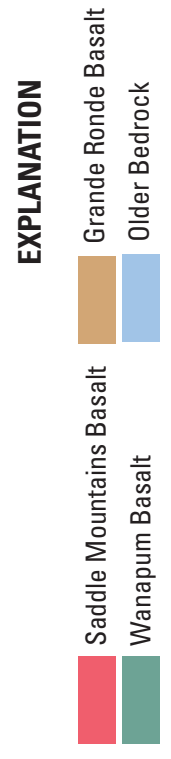

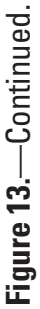



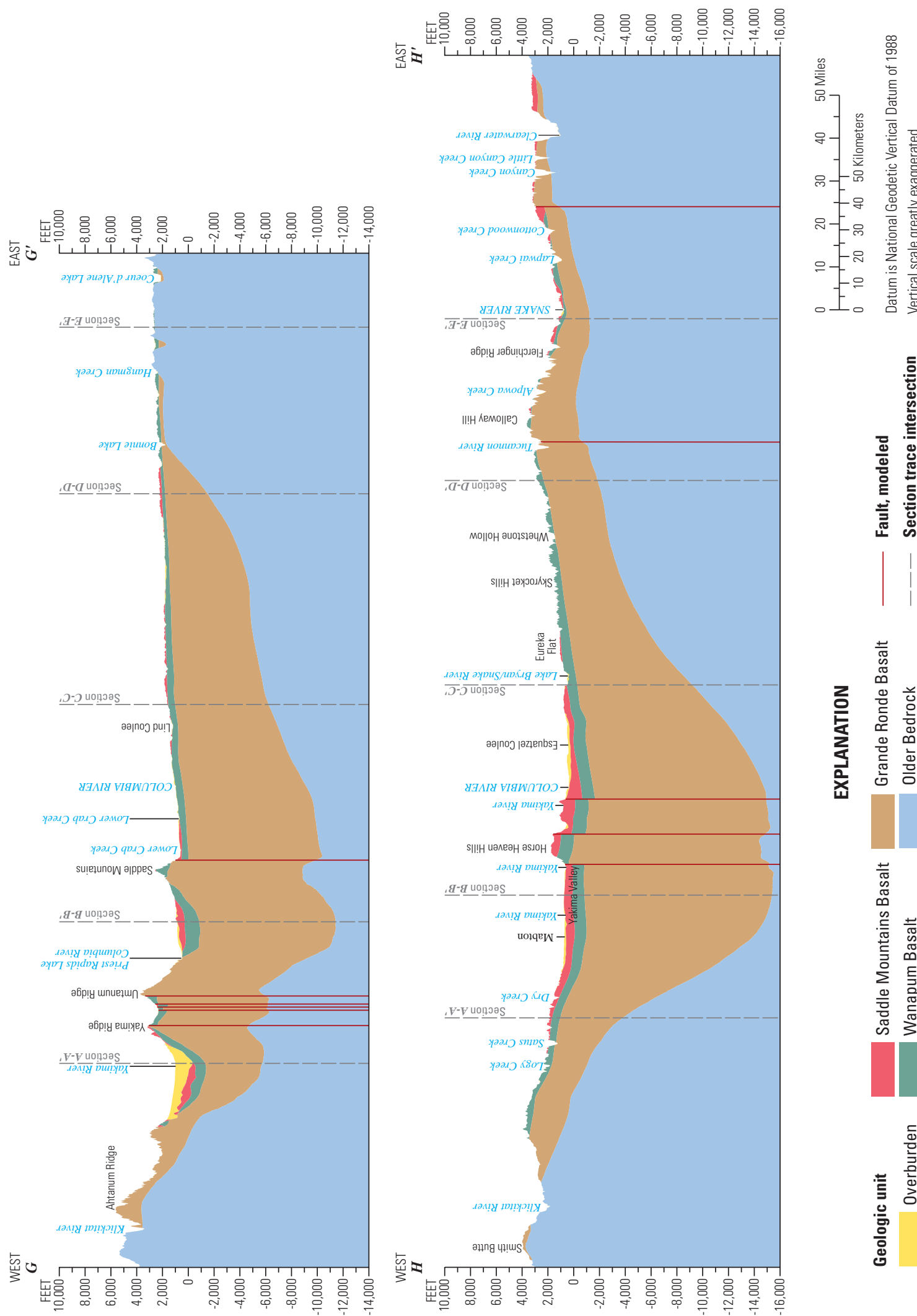

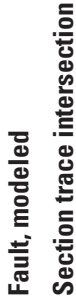
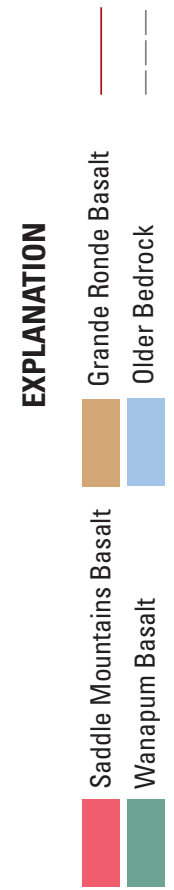

1. 

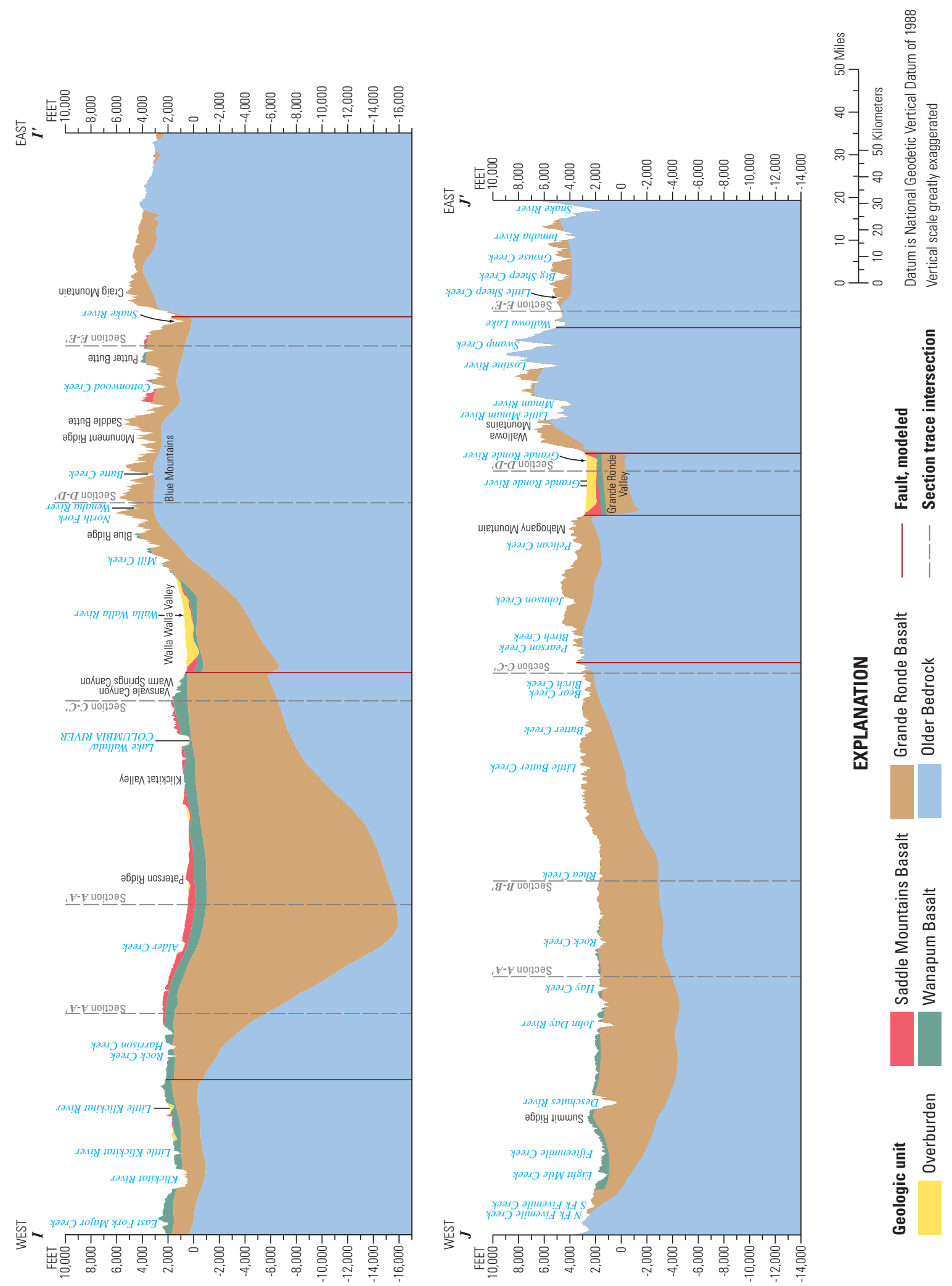

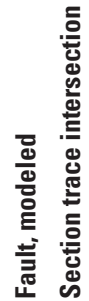
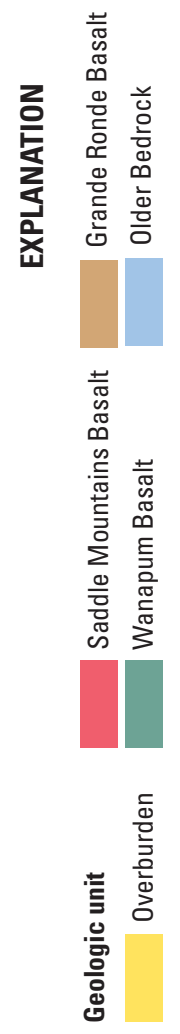

ن. 


\section{Mabton Interbed Unit}

Generally, the Mabton interbed is everywhere that the overlying Saddle Mountains Basalt occurs, although locally, it may not be present because of local variability in the paleodepositional environment. In the western faultbounded basins, thickness patterns are visually apparent and are correlated to thicker deposits of Saddle Mountains Basalt. Variability is relatively high, with anomalously thick deposits being reported in some wells with no corroborating evidence in nearby wells.

On a regional scale, it is assumed that interbeds transmit water much less efficiently than the CRBG aquifers and commonly are classified as "confining units." Because interbeds are sedimentary units, however, interbeds may store an appreciable amount of water per unit volume that may be released during transient conditions. Therefore, if the volume of the unit is significant at a given location, it may supply an appreciable amount of water to the aquifer system. The volume of the Mabton interbed is the property needed for groundwater flow simulation, and the discontinuous nature of the deposits is less important.

To better understand the typical volume of the interbed, the thickness of the interbed must be estimated. It is assumed that thicker interbeds correspond to thicker deposits of the overlying basalt. A best linear fit between all Mabton interbed thickness data and modeled Saddle Mountains Basalt thickness (constrained to pass through the origin) was constructed (fig. 14) to estimate the relationship. Next, the 10 percent of the data with the worst fit was removed to minimize the outlier effect, followed by fitting an unconstrained line to the best 90 percent of the data. The equation of the best line is

$$
\text { thickness } s_{\text {Mabton }}=6.9 \% \cdot \text { thickness }_{\text {SaddleMountain }}+18.4 \text {, }
$$

where units are in feet. The R-squared value for this equation is 0.34 . Constraining the line to pass through the origin yields a best-fit slope of 10 percent (meaning that the thickness of the Mabton is expected to be 10 percent of the thickness of the overlying Saddle Mountain Basalt) (fig. 14), with an $\mathrm{R}$-squared value of 0.25 . Although the correlation between thick Mabton interbeds and thick Saddle Mountains Basalt is evident when considering the spatial distribution of Mabton interbed deposits across the study area, the poor R-squared values result from the high variability of the interbed thicknesses at shorter spatial scales than is well defined by the trend models of the buried units. This variability in sedimentary interbed thickness likely was controlled by local hills and valleys in the paleotopography.
Because all data used for this analysis have reported Mabton interbed thicknesses, wells where the Mabton interbed does not occur are not represented, resulting in bias towards overestimating the average Mabton interbed thickness. This bias implies that the relations above are upper bounds for the average behavior of the Mabton interbed thickness. The assumption that the Mabton interbed is 10 percent (larger of the two computed line slopes in fig. 14) of the total distance between the top of the Wanapum Basalt and top of Saddle Mountains Basalt (fig. 10B) yields a maximum thickness of less than $300 \mathrm{ft}$, which is still lower than the largest reported values.

\section{Vantage Interbed Unit}

Similar to the Mabton interbed, the Vantage interbed generally is everywhere that the overlying Wanapum Basalt occurs, although locally it may not be present because of local variability in the paleodepositional environment. Again, the typical thickness of the interbed is the property needed for the hydrogeologic framework of the groundwater flow model, so a similar approach to that used for the Mabton Interbed unit was followed. In contrast to the Mabton interbed, the Vantage interbed shows no strong patterns in map-view or strong correlations to the thickness of Wanapum Basalt unit (fig. 15). Variability is high, with anomalously thick deposits being reported in wells with little or no corroborating evidence in nearby wells. The same procedure used for the Mabton Interbed unit to remove data outliers was used for the Vantage Interbed unit, with the equation of the best line being

$$
\text { thickness }_{\text {Vantage }}=0.4 \% \cdot \text { thickness }_{\text {Wanapum }}+18.1 \text {, }
$$

where units are in feet. The R-squared value for equation (2) is 0.004 , supporting the observation that there is little or no correlation between the thickness of the Vantage interbed and the overlying Wanapum Basalt thickness. Because there are no apparent regional spatial patterns of Vantage interbed thickness, the best estimators of thickness are assumed to be the mean value of $19.5 \mathrm{ft}$ and the median value of $15 \mathrm{ft}$, which are well supported by the near-constant value of the best-fit line. Again, zero-thickness values were not used in the analysis, indicating that this estimate may be an overprediction on average. Again, the poor R-squared value is an indication of the inability of the geologic model to represent paleotopographic features that controlled the deposition of thick and thin sedimentary deposits. 


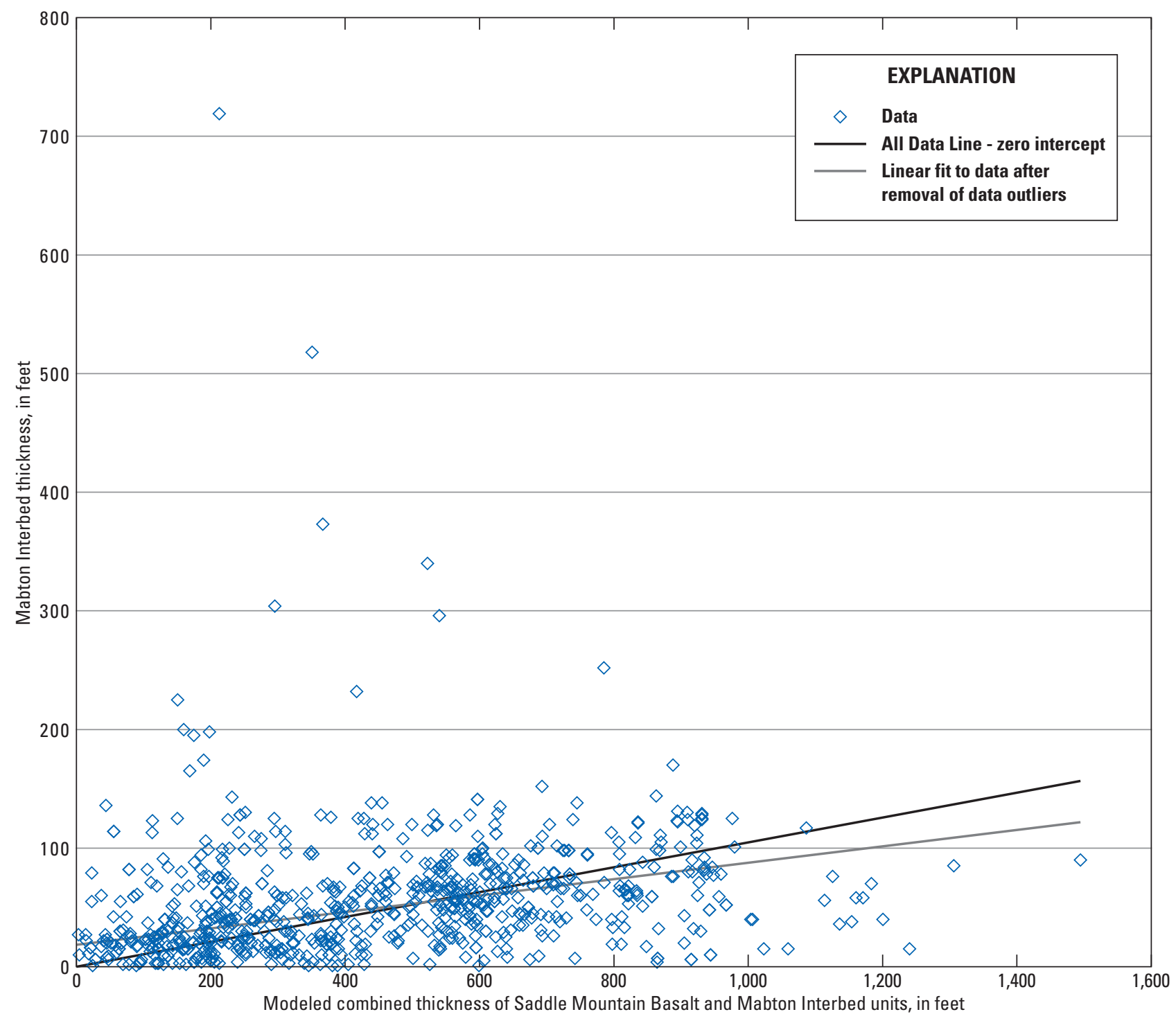

Figure 14. Correlation between the model-generated thickness of the Saddle Mountains Basalt unit and thickness of the Mabton interbed, Columbia Plateau regional aquifer system, Idaho, Oregon, and Washington. 


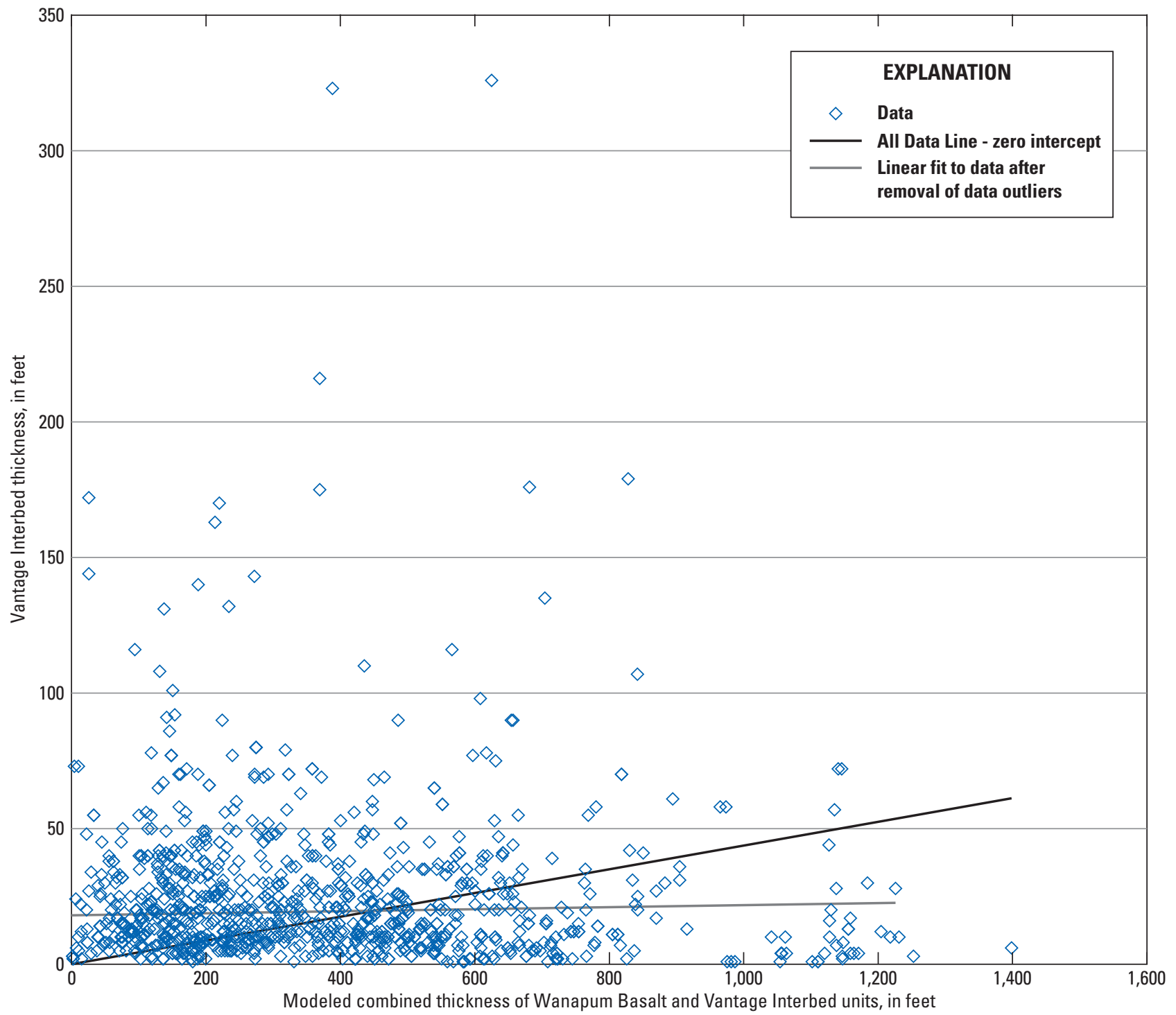

Figure 15. Correlation between the model-generated thickness of the Wanapum Basalt unit and thickness of the Vantage interbed, Columbia Plateau regional aquifer system, Idaho, Oregon, and Washington. 


\section{Applicability and Limitations}

The geologic model integrates a large number of different types of data to create a fully consistent three-dimensional representation of the large-scale geometry of the CPRAS. As such, it is the synthesis of the best current understanding gained from previous studies at various scales. Its error is quantifiable (fig. 11A-D), with the error being a function of the amount of data. The following list of limitations should be considered when using the results of this study:

- The data used to construct the surfaces contain errors. This fact is known because some studies did not agree on lithologic picks. These errors may cause bias in the interpreted surfaces. Many of the lithologic picks made for particular units are inferential on the basis of previous work, which may be the source of some errors.

- In most cases, data are not closely enough spaced to resolve features at a smaller scale than the trend model.

- Generally, error increases with depth because of limited amounts of data in many areas. Increased error with depth is evidenced in the residual histograms (fig. 11A-D). The top of the Older Bedrock unit has some bias and may be underestimated in the north and northwest where CRBG depositional style has changed from flood basalt to intracanyon flows.

- Error increases with distance from data. The error implied by the residual histograms may not be representative at points far from supporting data because the implicit assumption is that the trend surface is correct on average.

- Error in heavily folded or faulted areas is greater than for smoothly varying areas with moderate data support. The dataset was insufficient to resolve these features.

- The surfaces and thickness are generated using smooth trend surfaces representing unit tops and consequently result in smooth tops where buried. The model-generated values represent expected values at any subsurface location, but the true value likely will be somewhat different. Confidence that a unit will be located within a given range of elevations may be computed from the residuals.

The resulting geologic model provides important insights into the following:

- The model preserves important groundwater modeling characteristics. - If the trend model residuals are random and stationary, then, on average, the geometry of the system is correct. Good estimates of volume allow an improved understanding of aquifer storage parameters. Preservation of connectivity of large- scale features allows an improved understanding of potential groundwater flow paths within the system and connection with surface water.

- The error and uncertainty of the model-generated units can be estimated. - The model was created by creating trend surfaces. If the residuals are random and stationary, then the error of the model-generated surfaces is assumed to have the same statistical properties as the residuals, which forms the basis for quantifying the error.

\section{Summary and Conclusions}

A three-dimensional model of the major geologic units serving as aquifers within the Columbia Plateau regional aquifer system of Idaho, Oregon, and Washington, was developed. The model is at a scale and resolution appropriate for use as the foundation for a regional groundwater flow model. The model is completely consistent in that the computed bottom of any model-generated unit is coincident with the top of the uppermost model unit immediately underlying each unit, and the thickness of each unit is the difference between the unit top and unit bottom. Modelgenerated tops and bottoms of each unit are smooth where buried, reflecting the uncertainty in the estimated surface. These smooth surfaces were generated using loess trend modeling methods to decompose the data into well-supported trends and apparently random residuals. The variability of the residuals represents uncertainty and is the result of sampling an irregular buried paleotopography, measurement error, and interpretive error made when picking strata in well logs. Even if the data had been perfect, data density was insufficient to resolve the precise shape of the paleotopography. Because the residuals are representative of the uncertainty, the residuals may be used to estimate uncertainty in areas with no well picks or outcrop exposure of the unit. The final model was constructed using geologic principles to truncate trend surfaces against geologically bounding surfaces, thereby creating a complete representation of the geometry of all model-generated geologic units.

\section{Availability of Digital Surfaces}

The interpretive digital products developed in this report, consisting of 500-ft raster grids, are available in a geographic information system database format for free download (see "Data" at http://pubs.usgs.gov/sir/2010/5246). A mapdriven web browser tool also has been provided that allows interactive exploration of the geologic model (see "Interactive Webtool” at http://pubs.usgs.gov/sir/2010/5246). 


\section{Acknowledgments}

The authors thank the many people that contributed their time and knowledge to help complete this study. The following persons and organizations are noted for their special assistance in providing interpretive data from their work for use in this study: Columbia Basin Ground Water Management Area, Steve Reidel (Washington State University - Tri-Cities), and Farida Leek (Washington Department of Ecology Eastern Regional Office).

\section{References Cited}

Bjornstad, B.N., Babcock, R.S., and Last, G.V., 2007, Flood basalts and Ice Age floods - Repeated late Cenozoic cataclysms of southeastern Washington, in Stelling, P., and Tucker, D.S., eds., Floods, Faults, and Fire-Geological Field Trips in Washington State and Southwest British Columbia: Geological Society of America Field Guide 9, p. 209-255.

Cleveland, W.S., Grosse, E., and Shyu, W.M., 1992, Local Regression Models, chap. 8 of Chambers, J.M., and Hastie, T.J., eds., Statistical Models in S: Pacific Grove, Calif., Wadsworth \& Brooks/Cole Advanced Books \& Software, p. 309-376.

Deutsch, C.V., 2002, Geostatistical Reservoir Modeling, Applied Geostatistics Series: New York, Oxford University Press.

Davies-Smith, A., Bolke, E.L., and Collins, C.A., 1988, Geohydrology and digital simulation of the ground-water flow system in the Umatilla Plateau and Horse Heaven Hills area, Oregon and Washington: U.S. Geological Survey Water-Resources Investigation Report 87-4268, 72 p.

Drost, B.W., and Whiteman, K.J., 1986, Surficial geology, structure, and thickness of selected geohydrologic units in the Columbia Plateau, Washington: U.S. Geological Survey Water-Resources Investigations Report 84-4326, 11 sheets.

Drost, B.W., Whiteman, K.J., and Gonthier, J.B., 1990, Geologic framework of the Columbia Plateau Aquifer System, Washington, Oregon, and Idaho: U.S. Geological Survey Water-Resources Investigations Report 87-4238, 10 p., 10 sheets.

Gonthier, J.B., 1990, Geology, structure, and thickness of the hydrogeologic units in part of the Columbia Plateau, Oregon: U.S. Geological Survey Water-Resources Investigations Report 86-4001, 6 sheets.
Jones, M.A., and Vaccaro, J.J., 2008, Extent and depth to top of basalt and interbed hydrogeologic units, Yakima River basin aquifer system, Washington: U.S. Geological Survey Scientific Investigations Report 2008-5045, 22 p.

Jones, M.A., Vaccaro, J.J., and Watkins, A.M., 2006, Hydrogeologic framework of sedimentary deposits in six structural basins, Yakima River basin, Washington: U.S. Geological Survey Scientific Investigations Report 20065116, 24 p.

Kahle, S.C., Olsen, T.D., and Morgan, D.S., 2009, Geologic setting and hydrogeologic units of the Columbia Plateau Regional Aquifer System, Washington, Oregon, and Idaho: U.S. Geological Survey Scientific Investigations Map 3088, 1 sheet. (Also available at http://pubs.usgs.gov/sim/3088/.)

Leek, F., 2006, Hydrogeological characterization of the Palouse Basin Basalt Aquifer System, Washington and Idaho: Pullman, Wash., Washington State University, M.S. thesis, $38 \mathrm{p}$.

Lindsey, K., Tolan, T., Nielson, M., and Loper, S., 2007, Geologic framework of the suprabasalt sediment aquifer system, Columbia Basin Ground Water Management area of Adams, Franklin, Grant, and Lincoln Counties, Washington, Edition 1: Prepared for Columbia Basin Ground Water Management Area by GSI Water Solutions, Inc., variously paged.

Packard, F.A., Hansen, A.J., Jr., and Bauer, H.H., 1996, Hydrogeology and simulation of flow and the effects of development alternatives on the basalt aquifers of the Horse Heaven Hills, south-central Washington: U.S. Geological Survey Water-Resources Investigations Report 94-4068, $92 \mathrm{p}$.

Reidel, S.P., Johnson, V.G., and Spane, F.A., 2002, Natural gas storage in basalt aquifers of the Columbia Basin, Pacific Northwest USA-A guide to site characterization: Richland, Wash., Pacific Northwest National Laboratory, 277 p., accessed November 5, 2010, at http://www.pnl.gov/ main/publications/external/technical_reports/PNNL-13962. pdf.

Richmond, G.M., Fryxell, R., Neff, G.E., and Weis, P.L., 1965, The Cordilleran ice sheet of the northern Rocky Mountains, and the related Quaternary history of the Columbia Plateau, in Wright, H.E., Jr., and Frey, D.G., eds., The Quaternary of the United States: Princeton, N.J., Princeton University Press, p. 231-242.

Snyder, D.T., and Haynes, J.V., 2010. Groundwater conditions during 2009 and changes in groundwater levels from 1984 to 2009, Columbia Plateau Regional Aquifer System, Washington, Oregon, and Idaho: U.S. Geological Survey Scientific Investigations Report 2010-5040, 12 p. (Also available at http://pubs.usgs.gov/sir/2010/5040/.) 
State of Washington, 2009, Natural Resources, NT15, Washington's rank in the Nation's agriculture: State of Washington Office of Financial Management website, accessed June 16, 2009, at http://www.ofm.wa.gov/ databook/resources/nt15.pdf.

Swanson, D.A., Anderson, J.L., Bentley, R.D., Byerly, G.R., Camp, V.E., Gardner, J.N., and Wright, T.L., 1979a, Reconnaissance geologic map of the Columbia River Basalt Group in eastern Washington and northern Idaho: U.S. Geological Survey Open-File Report 79-1363, 26 p., 12 sheets, scale 1:250,000.

Swanson, D.A., Anderson, J.L., Camp, V.E., Hooper, P.R., Taubeneck, W.H., and Wright, T.L., 1981, Reconnaissance geologic map of the Columbia River Basalt Group, northern Oregon and western Idaho: U.S. Geological Survey OpenFile Report 781-797, 35 p.

Swanson, D.A., Brown, J.C., Anderson, J.L., Bentley, R.D., Byerly, G.R., Gardner, J.N., and Wright, T.L., 1979b, Preliminary structure contour maps of the top of the Grande Ronde and Wanapum Basalts, eastern Washington and northern Idaho: U.S. Geological Survey Open-File Report 79-1364, 2 sheets, scale 1:500,000.

Swanson, D.A., Wright, T.L., Hooper, P.R., and Bentley, R.D., 1979c, Revision in the stratigraphic nomenclature of the Columbia River Basalt Group: U.S. Geological Survey Bulletin 1457-G, 59 p.

Tolan, T.L., Reidel, S.P., Beeson, M.H., Anderson, J.L., Fecht, K.R., and Swanson, D.A., 1989, Revisions to the estimates of the areal extent and volume of the Columbia River Basalt Group, in Reidel, S.P., and Hooper, P.R., eds., Volcanism and tectonism in the Columbia River flood-basalt province: Geological Society of America Special Paper 239, p. 1-20.
Tolan, T., Lindsey, K., Nielson, M., and Loper, S., 2007, Geologic framework of selected sediment and Columbia River Basalt units in the Columbia Basin Ground Water Management area of Adams, Franklin, Grant, and Lincoln Counties, Washington, Edition 2: Prepared for Columbia Basin Ground Water Management Area by GSI Water Solutions, Inc., variously paged.

U.S. Department of Agriculture, 2009, The Census of Agriculture-2007 Census Publications, U.S. Department of Agriculture, National Agricultural Statistics Service website, accessed June 16, 2009, at http://www.agcensus. usda.gov/Publications/2007/Online_Highlights/Rankings of_Market_Value/Washington/index.asp.

U.S. Geological Survey, 2009a, Columbia River Basalt stratigraphy in the Pacific Northwest: U.S. Geological Survey website, accessed November 2, 2010, at http:// or.water.usgs.gov/projs dir/crbg/.

U.S. Geological Survey, 2009b, USGS groundwater data for Oregon: U.S. Geological Survey website, accessed May 4, 2009, at http://waterdata.usgs.gov/or/nwis/gw.

Waitt, R.B., Jr., and Thorson R.M., 1983, The Cordilleran ice sheet in Washington, Idaho, and Montana, in Wright, H.E., and Porter, S.C., eds., Late-Quaternary environments of the United States, v. 1.: Minneapolis, University of Minnesota Press, p. 53-70.

Whiteman, K.J., Vaccaro, J.J., Gonthier, J.B., and Bauer, H.H., 1994, The hydrogeologic framework and geochemistry of the Columbia Plateau aquifer system, Washington, Oregon, and Idaho: U.S. Geological Survey Professional Paper 1413-B, 73 p.

Wilson, M.S., Dyman, T.S., and Condon, S.M., 2008, Evaluation of well-test results and the potential for basincenter gas in the Columbia Basin, central Washington, chap. 4 of Geologic Assessment of Undiscovered Gas Resources of the Eastern Oregon and Washington Province: U.S. Geological Survey Digital Data Series DDS-69-0. 
Publishing support provided by the U.S. Geological Survey

Publishing Network, Tacoma Publishing Service Center

For more information concerning the research in this report, contact the Director, Washington Water Science Center

U.S. Geological Survey

934 Broadway, Suite 300

Tacoma, Washington 98402

http://wa.water.usgs.gov 
